\title{
MECHANICAL PROPERTY AND FORMABILITY STUDIES ON UNALLOYED PLUTONIUM
}

By

H. R。 Gardner and I。 B。 Mann

Plutonium Metallurgy

Reactor and Fuels Reasearch and Development Operation

December 1959

\section{HANFORD ATOMIC PRODUCTS OPERATION RICHLAND, WASHINGTON}

Work performed under Contract No. AT (45-1)-1350 between the Atomic Energy Commission and General Electric Company

Printed by/for the U。S.Atomic Energy Commission 


\section{DISCLAIMER}

This report was prepared as an account of work sponsored by an agency of the United States Government. Neither the United States Government nor any agency Thereof, nor any of their employees, makes any warranty, express or implied, or assumes any legal liability or responsibility for the accuracy, completeness, or usefulness of any information, apparatus, product, or process disclosed, or represents that its use would not infringe privately owned rights. Reference herein to any specific commercial product, process, or service by trade name, trademark, manufacturer, or otherwise does not necessarily constitute or imply its endorsement, recommendation, or favoring by the United States Government or any agency thereof. The views and opinions of authors expressed herein do not necessarily state or reflect those of the United States Government or any agency thereof. 


\section{DISCLAIMER}

Portions of this document may be illegible in electronic image products. Images are produced from the best available original document. 


\section{ABSTRACT}

The effect of temperature and testing speed on the tension and compression properties of unalloyed plutonium were studied in the alpha, beta, gamma and delta phases. Compressive formability data were obtained for a load of 100,000 pounds in the aforementioned phases. In addition, preliminary creep, tension impact and torsion data for alpha phase plutonium are reported.

Extrusion constants and pressures for the beta, gamma and delta phases were obtained. The room temperature tension and compression properties of the beta and gamma extruded plutonium were determined.

Metallographic studies were made to determine the effect of tension, compression and extrusion, in the indicated phases, on the microstructure of as-cast plutonium. 
TABLE OF CONTENTS

INTRODUCTION .

SUMMARY AND CONCLUSIONS

GENERAL EXPERIMENTAL TECHNIQUES

Specimen Preparation Procedure .

$\underline{\text { Page }}$

Metallographic Procedure

METALLOGRAPHY OF AS-CAST PLUTONIUM 。

TENSILE PROPERTY STUDIES

Experimental Material and Testing Techniques 。 . . . 6

Results and Discussion. 。 . . . . . . 。 . . . 6

1. Effect of Test Temperature . . . . . . 6

2. Effect of Testing Speed 。 . . . . . . . 9

COMPRESSION AND FORMABILITY STUDIES 。 . . . . . 10

Experimental Material and Testing Techniques . . . . 10

Results and Discussion . . . . . . . . . 11

1. Compression Properties at $30 \mathrm{C}$. . . . . 11

2. Effect of Temperature . . . . . . . 12

3. Formability Studies 。 . . . . . . . 14

4. Effect of Testing Speed . . . . . . . . . 16

CREEP TESTING 。 . . . . . . . . . . 17

Experimental Material and Testing Techniques 。 . . 17

Results and Discussion。 . . . . . . . . . . . 18

TENSION IMPACT TESTING . . . . . . . . . . 19

Experimental Material and Testing Techniques . . . . 19

Results and Discussion. 。 . . . . . . . . . 19

TORSION TESTING 。 。 . . 。 . . 。 . . . 19

BETA , GAMMA AND DELTA PHASE EXTRUSION . . . . . 20

Experimental Material and Procedure 。 . 。 . . 20

Results and Discussion. . . . . . . . . . . 20

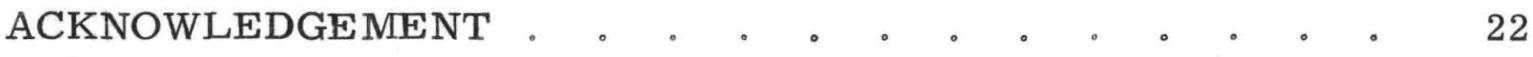

BIBLIOGRAPHY 。 。 。 . 。 。 . . . . . 23

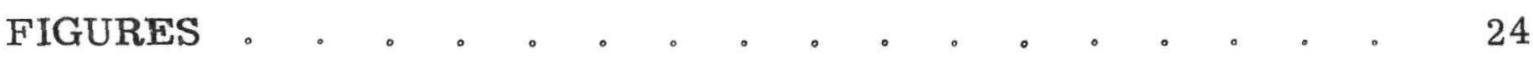

TABLES 。 。 . . . . . . . . . 67 


\title{
MECHANICAL PROPERTY AND FORMABILITY STUDIES ON UNALLOYED PLUTONIUM
}

\author{
H. R。 Gardner and I。 B。 Mann
}

\section{INTRODUCTION}

The mechanical properties of a material must be determined before it can receive extensive usage in engineering applications. In the case of plutonium the number of such applications is relatively small, but their importance places a high priority on mechanical property data. Accordingly, studies were initiated on tensile, compression, creep, tension impact and torsion properties. The effects of temperature and testing speed in tension and compression were determined.

To obtain data on the formability of plutonium, a study of the extrusion characteristics of the beta, gamma, and delta phases was initiated. The room temperature tensile and compression properties of beta and gamma extruded plutonium were determined.

\section{SUMMARY AND CONCLUSIONS}

The effect of temperature on the tension and compression properties of as-cast plutonium was determined in the alpha, beta, gamma and delta phases. In general, the effect of increasing temperature is to decrease strength and increase ductility. The alpha phase is quite brittle, while the beta, gamma and delta phases are very ductile. The beta phase has the greatest ductility; at $160 \mathrm{C}$ and a testing speed of $0.015 \mathrm{inch} / \mathrm{minute}$, elongations up to 620 per cent and reductions in area of 100 per cent are obtained. Despite the apparent brittleness of the alpha phase, it is interesting to note that the elongation data obtained in 
both tension and compression indicate that between 30 and $70 \mathrm{C}$ a change in deformation mechanism, possibly caused by recrystallization, is taking place. In addition, the total plastic deformations obtained prior to fracture during compression testing in the alpha phase indicate that it may be possible to accomplish limited dimensional sizing operations without fracture.

As expected, the effect of increasing metal purity was to decrease strength values. Formability studies in compression indicated that the delta phase had the greatest formability. Metallographic observations indicate that forming in the beta, gamma and delta phases generally results in a non-uniform grain structure. Microcracks were also observed in formed specimens; however, since microcracking was present in most of the ascast specimens, it is expected that this had a great influence on the microcracking observed after forming. It is concluded that forming operations should be supplemented by metallographic studies to evaluate the integrity of formed parts.

Determinations of the effect of testing speed on tension and compression properties in the alpha, beta and gamma phases produced varied results. In the alpha phase, strength values increased to a maximum and then decreased. Beta phase strength values increased rapidly with increasing testing speed, while the increase in gamma phase strength was relatively small. Elongation in the beta phase decreased rapidly with increasing testing speed, the effect on gamma phase elongation was much smaller.

Since gamma phase properties are not affected by testing speed as much as beta phase properties, the gamma phase would probably be more amenable to hot forming operations. However, it must be kept in mind that the degree of microcracking originally present in the as-cast microstructure may greatly influence the integrity of formed parts.

In view of the apparent effect of the $\mathrm{Pu}-\mathrm{Pu}_{6} \mathrm{Fe}$ eutectic in inhibiting microcracking it may be beneficial from a metal integrity standpoint to specify a certain amount of iron in plutonium to be used in forming operations.

During preliminary creep studies it was determined that alpha phase secondary creep rates are low, as are the total plastic deformations obtained. At a stress of 10,000 psi, creep rates varied from 15 to $330 \times 10^{-4}$ in. $/ \mathrm{in} . / 10,000$ hours for test temperatures of 31 and $100 \mathrm{C}$, respectively. 
A brittle fracture was obtained in room temperature tension impact testing. Impact energy values ranged from 1.3 to 4.8 foot-pounds with an average of 2.6 foot-pounds.

An average of 52,500 psi was obtained for the ultimate shear strength in torsion.

Extrusion in the beta, gamma and delta phases was determined to be a feasible fabrication method for as-cast plutonium. Extrusion constants and pressures decrease as temperature is increased through the beta to delta phases. Non-uniform grain structures which may indicate the presence of deleterious residual stresses were present after extrusion. Room temperature tensile strength is increased approximately 10 per cent by extrusion, while compressive strength was not affected.

\section{GENERAL EXPERIMENTAL TECHNIQUES}

\section{Specimen Preparation Procedure}

Unless stated differently, the following specimen preparation procedures apply to all specimens used to obtain data for this paper.

Plutonium buttons of nominal purity were charged into $\mathrm{MgO}$ crucibles for melting. The metal charged for each casting heat ranged from 1200 to 3000 grams. The plutonium was melted in vacuo and held at $950 \mathrm{C}$ for 30 minutes before pouring into a multicavity $\mathrm{MgO}$ coated graphite mold which had been heated to 300 C. When the mold cooled to $150 \mathrm{C}$, the castings were removed and cooled slowly to room temperature in the normal air atmosphere of the glove box.

Prior to machining to specimen dimensions at room temperature, the castings were cold treated for several hours at -23 to $-34 \mathrm{C}$. Samples for chemical analysis were taken on the machining cut just before the finish cut on the specimens. Metallographic Procedure

Metallographic specimens were taken from each casting heat and mounted in Thalco polyester resin which sets at room temperature. The initialsurface preparation consisted of hand polishing on paper ranging from 180 to 600 grit using carbon tetrachloride as a lubricant. An acceptable as-polished surface was produced by automatic polishing on Syntron Vibratory polishers for two hours using a Linde A emulsion in carbon tetrachloride on billiard cloth. All photomicrographs 
not containing grain structures, were taken of the as-polished surface under bright field illumination. Electropolishing for grain structure and electroetching for inclusion studies were both accomplished in a solution of 20 parts tetraphosphoric acid, 30 parts water and 50 parts 2-ethoxyethanol at 21 volts and 0,15-0,30 amperes. A 10-second time was used for electroetching while 60 seconds was sufficient for electropolishing. The grain structure of alpha plutonium is readily apparent under polarized illumination after the 60-second electropolish and a 5 to 15-hour oxidation period. Longer electropolishing times decrease the oxidation period.

\section{METALLOGRAPHY OF AS-CAST PLUTONIUM}

To evaluate the quality of the plutonium used, metallographic specimens taken from each casting heat were examined in both the as-polished and electropolished conditions. Microcracking which varied between the extremes illustrated in Figures 1 and 2 was observed in most of the specimens. As would be expected, as the size of the microcracks increases, density decreases. An unidentified spherical inclusion which was quite common in the microstructure is illustrated in Figure 3. In a few of the specimens a network of $\mathrm{Pu}-\mathrm{Pu}_{6} \mathrm{Fe}$ eutectic was ppresent, Figures 4 and 5 . In addition, unidentified small white particulate inclusions were present in casting heat 19-2-2, Figure 4. Plutonium nitride inclusions were also observed in a number of specimens.

Comparison of Figures 1 and 2 with Figures 4 and 5 indicates that the presence of a fairly large amount of $\mathrm{Pu}-\mathrm{Pu}_{6} \mathrm{Fe}$ eutectic, about $500 \mathrm{ppm}$ Fe or greater, tends to inhibit the formation of microcracks. Russian investigators have found that $\mathrm{Pu}-\mathrm{Pu}_{6} \mathrm{Fe}$ has good ductility, ${ }^{[1]}$ and herein may lie the answer to its apparent inhibiting effect on microcracking. When the $\mathrm{Pu}-\mathrm{Pu}_{6} \mathrm{Fe}$ eutectic is present in sufficient quantities in the microstructures, the plastic strains accompanying the phase transformations during cooling after casting may be taken up in the $\mathrm{Pu}-\mathrm{Pu}_{6} \mathrm{Fe}$ and not the plutonium matrix. When the $\mathrm{Pu}-\mathrm{Pu}_{6} \mathrm{Fe}$ is not plentiful the plastic strains are dissipated in the plutonium with subsequent formation of microcracks. The typical grain structure present in all casting heats is illustrated in Figure 6. In all specimens, the as-cast average grain diameter ranged from 0.017 to $0.070 \mathrm{~mm}$ with an over-all average of $0.040 \mathrm{~mm}$. 


\section{TENSILE PROPERTY STUDIES}

\section{Experimental Material and Testing Techniques}

The chemical impurities, densities and grain sizes for the plutonium used in the tensile property studies are presented in Table I.

The 0.250-inch diameter tensile specimens, Figure 7, were tested on a 440, 000 pound Baldwin-Lima-Hamilton Universal Testing Machine equipped with a glove box mounted between the adjustable and fixed crossheads。 ${ }^{[2]}$

The effect of testing temperature was studied over a temperature range of -30 to $325 \mathrm{C}$ at a testing speed of $0.015 \mathrm{inch} /$ minute. Peanut oil was used as a heating medium for the elevated temperature work and tri-chloroethylene and dry ice for the low temperature work. Through vigorous agitation in the bath it was possible to maintain a temperature control of $\pm 1.5 \mathrm{C}$ during testing.

In the alpha phase a linear differential transformer type extensometer was used to obtain a stress-strain curve ${ }^{[2]}$ from which 0.01 per cent yield strength, modulus of elasticity and elongation data could be determined. All elongation data are based on a one-inch gage length.

In the beta, gamma and delta phases the large amount of thermal expansion that had taken place on heating from room temperature eliminated most extensometer systems from use. To gain an indication of yielding, a Baldwin Platen Deflectometer was used to obtain a graph of load versus displacement during testing. A typical curve is illustrated in Figure 24, curve (B). It was not possible to obtain an offset yield strength from curves of this type because of the low sensitivity of the deflectometer. However, since the curves have a straight line portion, the point of demarkation (C), from the straight line was defined as the yield strength. This type of yield strength data was obtained in the beta, gamma and delta phases.

Modulus of elasticity data in the beta, gamma and delta phases was obtained on 0.505 -inch diameter tensile specimens with a Martins 
Extensometer ${ }^{[3]}$, Figure 8. Elongation in the specimen is transmitted through four parallel rods to two mirrors which rotate as the specimen elongates. The rods are linked to the specimen through taper pins at either end of the two-inch gage length. The pins are inserted in tapered holes drilled through the gage diameter. The amount of mirror rotation is followed optically with a cathetometer and scale. A simple calibration using either a specimen of known elastic modulus or the geometry of the system relates mirror rotation to strain in the specimen.

Elongation, based on a one-inch gage length, and reduction in area in the beta, gamma and delta phases were obtained using the conventional techniques of punch marks and diameter at fracture measurements, respectively. Testing speed, the rate of platen motion, was controlled by a Baldwin Platen Motion Pacer.

$\underline{\text { Results and Discussion }}$

\section{Effect of Test Temperature}

In general, as test temperature is increased through the alpha to delta phases, both strength and modulus of elasticity values decrease, Figures 9 and 10, Tables II and III. Note that the low temperature gamma region has somewhat higher strength and modulus values than the high temperature beta region. Since elongation in the alpha phase is less than 1 per cent, it is not possible to obtain elongation data by measuring between punch marks on the one-inch gage length after fracture. However, by drawing a line parallel to the elastic portion of the stress-strain curve, from the fracture point to its intersection with the strain axis, it is possible to obtain elongation data, Figure 11. Note that there is a 600 per cent increase in elongation from 0.065 per cent at $30 \mathrm{C}$ to 0.46 per cent at $70 \mathrm{C}$. This may indicate that a change in the type of deformation mechanism is taking place, possibly caused by recrystallization. A typical brittle fracture was obtained at all alpha phase test temperatures.

In the beta phase, elongation and reduction in area are very high, Figure 12. The average elongation ranges from 295 to 570 per cent, while 
the reduction in area is nominally 100 per cent. The decrease in beta phase elongation from the 570.4 and 503.2 per cent values at 160 and $180 \mathrm{C}$ to the 325.9 per cent result at $190 \mathrm{C}$ is attributed to the occurrence of beta to gamma transformation during testing and will be discussed later in the paper with the $200 \mathrm{C}$ test results.

Both elongation and reduction in area are much lower in the gamma phase and little change occurs with increasing temperature. The average elongation ranges from 50.0 to 57.2 per cent while the reduction in area increases slightly from 75.0 to 82.8 per cent. The 67.3 per cent average elongation in the delta phase at $325 \mathrm{C}$ is significantly greater than the 50.1 per cent average gamma phase elongation at $300 \mathrm{C}$. The average reduction in area in the delta phase, 98.0 per cent, is 19 per cent greater than the average gamma phase value at $300 \mathrm{C}, 82.8$ per cent.

The type of deformation and fracture exhibited in the beta, gamma and delta phases is illustrated in Figures 13, 14 and 15.

Metallographic samples were taken at the point of fracture from beta, gamma and delta phase tested specimens. A typical microstructure for the $160 \mathrm{C}$ test temperature is illustrated in Figures 16 and 17 . Note the large number of elongated microcracks, also the elongated $\mathrm{Pu}-\mathrm{Pu}{ }_{6} \mathrm{Fe}$ eutectic and unidentified spherical inclusions. The accompanying grain structure is non-uniform with columnar grains in some areas and no alignment of grains in the tension direction, Figure 18. The axes of the columnar grains are perpendicular to the loading direction and they appear to be nucleated at the elongated inclusions and/or microcracks. Since nucleation at these imperfections would occur earlier than in the base metal, columnar grain growth would take place during the beta to alphatransformation. Any grain alignment in the tension direction which existed in the beta phase would probably be essentially erased by the beta to alpha transformation.

Three types of fractures were observed after gamma phase testing at $265 \mathrm{C}$, Figures 19, 20 and 21. The reason for the difference between the types in Figures 19 and 20 may be the size of microcracks originally present. The average size of mic rocracks in Figure 20 appear to be somewhat larger than those in Figure 19. 
The effect of the presence of microcracks on the elongation and reduction in area in the gamma phase is illustrated in Figures 14, 19, 20 and 21. Microcracks were present before testing in the specimens illustrated in Figures 19 and 20, while the specimen in Figure 21 had an extensive network of $\mathrm{Pu}-\mathrm{Pu}_{6} \mathrm{Fe}$ eutectic and no microcracks. The upper specimen in Figure 14 had extensive $\mathrm{Pu}-\mathrm{Pu}_{6} \mathrm{Fe}$ eutectic and no microcracks, while the lower specimen had extensive microcracking. Thus, when microcracks are absent from the microstructure, greater elongation and reduction in area can be expected. In addition, the gamma phase strength data indicate that slightly higher strengths are obtained with specimens containing no microcracks.

The alpha phase grain structure observed after testing in the gamma phase at $265 \mathrm{C}$ is uniform and has about the same grain size as observed in as-cast plutonium, Figure 22 .

A typical fracture in the delta phase at $325 \mathrm{C}$ is illustrated in Figure 23. Note the elongated microcracks along loading axis. The alpha phase grain structure after delta phase testing is uniform with about the same grain size as cast plutonium.

Note that in the foregoing discussion no mention has been made of the $200 \mathrm{C}$ test temperature results, Table III. The reason for this is because of the rather unique properties obtained at this temperature. A typical stress-platen displacement curve for the $200 \mathrm{C}$ test temperature, Curve (A), is illustrated in Figure 24 along with a typical curve for the beta, gamma and delta phases, Curve(B). For the $200 \mathrm{C}$ curve, the stress initially increases to a maximum and then decreases slightly prior to increasing to a stress higher than the initial maximum. This phenomenon was not observed at any of the other test temperatures which have stressplaten displacement curves similar to Curve (B). An explanation for this can be offered if it is noted that the 2700 psi stress value corresponding to the first maximum in the $200 \mathrm{C}$ curve falls on an extrapolation of the beta phase ultimate strength curve, Figure 9, while the 3800 psi stress at the second maximum falls between extrapolations of the beta and gamma phase ultimate strength curves at $200 \mathrm{C}$. This observation suggests the possibility of partial beta to gamma transformation occurring which would 
result in the somewhat higher ultimate strength observed in the second maximum in the curve, since the low temperature gamma phase is stronger than the high temperature beta phase.

This argument is substantiated by recent British data ${ }^{[4]}$ which established the thermo-dynamic equilibrium temperature for the beta to gamma transformation as $184 \mathrm{C}$. Thus, considering the six to seven-hour duration of tensile tests at the $200 \mathrm{C}$ temperature and also at $190 \mathrm{C}$, it is not surprising that partial transformation of beta to gamma plutonium occurred during testing. Since elongation in the gamma phase is much lower than in the beta phase the decrease in elongation observed at the 190 and $200 \mathrm{C}$ temperatures is consistent with what would be expected.

\section{Effect of Testing Speed}

In the alpha phase, the effect of testing speed was studied at 30 and $110 \mathrm{C}$. At both temperatures the ultimate strength increases to a maximum at the 0.250 inch/minute testing speed and then decreases, Figure 25 and Table IV. The initial increase in strength as testing speed is increased can be attributed to strain hardening. The decrease at the higher testing speeds is probably the result of an increase in the notch sensitivity of plutonium which is characteristic of many metals at high testing speeds. Because of an extensometer limitation it was not possible to determine yield strengths over the full range of testing speeds.

Both ultimate and yield strength increase rapidly with testing speed for all test temperatures in the beta phase, Figure 26 and Table V. For the 130 and $160 \mathrm{C}$ test temperatures, elongation decreases rapidly as testing speed increases. However, for the $190 \mathrm{C}$ temperature, the elongation is lower at the $0.015,0.060$, and $0.250 \mathrm{in}$./ min testing speeds than would be expected. This is caused by partial gamma transformation as explained in the preceeding section. At the $1.0 \mathrm{in} . / \mathrm{min}$ testing speed the total testing time is too short to allow enough beta to gamma transformation to occur to influence the test results. Reduction in area at the 130 and $160 \mathrm{C}$ temperatures decreases with increasing testing speed while at $190 \mathrm{C}$, elongation remains constant at approximately 100 per cent. The type of deformation and fracture exhibited at the different testing speeds at $160 \mathrm{C}$ is illustrated in Figure 28. 
In the gamma phase at $265 \mathrm{C}$, both ultimate and yield strengths increase by 100 per cent when testing speed is increased from 0.002 to $1.0 \mathrm{in} . / \mathrm{min}$. Elongation decreases by 40 per cent while reduction in area decreases by 25 per cent, Figures 26, 27 and Table V. The effect of testing speed on the deformation and fracture obtained in the gamma phase is illustrated in Figure 29.

Since gamma phase properties are not affected by testing speed as much as beta phase properties, the gamma phase would probably be most amenable to warm forming operations. However, it must be kept in mind that the degree of microcracking originally present in the as-cast microstructure may greatly influence the integrity of formed parts.

\section{COMPRESSION AND FORMABILITY STUDIES}

Experimental Material and Testing Techniques

Approximately $2 / 3$ of the compression specimens used were machined from as-cast and cold-treated cylinders. The remaining specimens were machined from the strain free grip ends of previously tested 0.500-inch diameter tensile specimens. The average and range of chemical impurities, density, and grain size in the plutonium used are presented in Table VI.

A 440, 000 pound Baldwin-Lima-Hamilton Universal Testing Machine equipped with a glove box mounted between the platen and the adjustable crosshead was used for the compression testing.

Prior to the study of the compressive properties of plutonium, it was necessary to establish the proper specimen height-diameter ratio. It is stated in the literature ${ }^{[5]}$ that the optimum height-diameter ratio for compression specimens should fall in the range of 1.5 to 10。0. Furthermore, a height-diameter ratio of 2.0 is most commonly employed. With this in mind, 0.500-inch diameter specimens with height-diameter ratios of 2.2 and 3.3 were prepared. During compression testing these specimens buckled at a stress of approximately $110,000 \mathrm{psi}$, Figure 30, which indicated that the height-diameter ratios were too high. Note that peripheral cracks were developed in the region of greatest bending.

To overcome buckling, specimens with height-diameter ratios of $1.0,1.25$, 1.5 and 1.75 were tested. The specimens with height-diameter ratios of 1.0 and 1. 25 shattered violently and flew apart at ultimate compressive strengths ranging 
from 162, 000 to 178, 000 psi, Figure 31. The specimens with an height-diameter ratio of 1.5 failed by shearing at an approximate $45^{\circ}$ angle, at ultimate strengths of 175, 200 and 178, 600 psi, Figure 32a. The 1. 75 height-diameter ratio specimens failed by shearing at strengths of 164,400 and $167,800 \mathrm{psi}$, however, they were observed to buckle slightly prior to failure. Since the 1.5 height-diameter ratio specimens, 0.500-inch diameter by 0.750-inch length, produced the desired $45^{\circ}$ shear failure without buckling, this height-diameter ratio was selected as the standard for compressive strength determinations in the alpha, beta, gamma and delta phases. The relatively short length of this specimen eliminates most extensometer systems from use. Thus, the Platen Deflectometer, described earlier in this paper, was used to obtain load-platen displacement curves. Yield strengths for the alpha, beta, gamma and delta phase regions were obtained from these curves in the way described earlier.

To obtain 0.01 per cent yield strength and modulus of elasticity data at $30 \mathrm{C}$, a linear differential transformer type extensometer was used on specimens 0.500 inch in diameter by 2.75 inches long.

Both the elevated temperature and below room temperature testing were conducted in an open container which allowed both upper and lower compressive bearing surfaces to be heated or cooled to the desired test temperature. Heating and cooling mediums, as well as temperature control were the same as in the tensile work.

Results and Discussion

1. Compression Properties at $30 \mathrm{C}$

A total of 27 specimens with 1.5 height-diameter ratios were tested at $30 \mathrm{C}$ to establish the ultimate compressive strength. Yield strengths were determined for approximately half of the specimens tested(see Table VII). Unfortunately the chemical analysis data obtained on the specimens were not accurate enough to use in a correlation of compres sive strengths with impurity constituents. However, on each test specimen, accurate density data were obtained which reflect the quality of the plutonium. Accordingly, the ultimate strength data were separated into two groups, one for specimens with densities less than $19.50 \mathrm{~g} / \mathrm{cc}$ and the other for densities equal to or greater than $19.50 \mathrm{~g} / \mathrm{cc}$, Table VII. The average ultimate compressive strength for the high density group is only 6, 500 psi greater than the low density group. Thus the density variations in the alpha phase at $30 \mathrm{C}$ had an almost 
negligible effect on ultimate compressive strength. Sufficient data were not available to make the same comparison on a yield strength basis. Note that for most of the metal groups, the ultimate compressive strength values within any particular metal group agree very closely。

Modulus of elasticity and 0.01 per cent yield strength data at $30 \mathrm{C}$ were obtained on five specimens with height to diameter ratios of 5.5 , Table VIII.

In comparison with the 59,100 psi ultimate strength in tension [5] the ultimate compressive strength, 175, 000 psi, is 200 per cent higher. The average compressive 0.01 per cent yield strength, $38,200 \mathrm{psi}_{2}$ is 19 per cent higher than the tensile 0.01 per cent yield strength, 32, 100 psi. The average values for the modulus of elasticity in both compression and tension are identical, at $14.3 \times 10^{6} \mathrm{psi}$.

Prior to failure in specimens with height-diameter ratios of 1.5 or less, extensive barreling is produced, Figure 32a. In particular, a specimen with a height-diameter ratio of 1.0 increased 8.2 per cent in diameter and decreased 11.5 per cent in length after loading to 164,000 psi and unloading for measurement and visual observation. No visible surface cracks were apparent and the specimen ultimately failed at 178,000 psi。

As indicated above, in addition to barreling, appreciable axial plastic deformation was produced in the specimens prior to failure. The total plastic deformation in length ranged from 18.6 to 26. 4 , with an average of 22.8 per cent.

\section{Effect of Temperature}

As illustrated in Figure 33 and Table IX, the effect of temperature on the compression properties of plutonium at a testing speed of $0.015 \mathrm{inch} /$ minute is quite marked. In the brittle alpha phase, both the ultimate and yield strengths decrease approximately 60 per cent over the temperature range -30 to $110 \mathrm{C}$.

Ductility in the alpha phase is low compared to the beta, gamma and delta phases; a typical brittle, shear type fracture with some 
barreling was obtained at all alpha phase test temperatures, Figure $32 \mathrm{a}$ and 32b. As reported in Table IX the total plastic decrease in length prior to fracture increased from 4.5 per cent at $-30 \mathrm{C}$ to 26.5 per cent at $70 \mathrm{C}$, a decrease to 18.3 per cent was observed at the $110 \mathrm{C}$ test temperature.

During this study it was determined that increases in the density of compression specimens could be obtained by compression at 100 and $110 \mathrm{C}$. A specimen compressed to $83,000 \mathrm{psi}$ at $100 \mathrm{C}$ increased in den= sity, measured at $30 \mathrm{C}$, from 19.41 to $19.55 \mathrm{~g} / \mathrm{cc}$, a 0.73 per cent increase. Another specimen compressed to 63,500 psi at $110 \mathrm{C}$ exhibited 0.46 per cent density increase from 19.55 to $19.64 \mathrm{~g} / \mathrm{cc}$. No indication of fracture or impending failure could be observed during visual examination of the specimens.

While testing specimen $\mathrm{D}-5$ at $70 \mathrm{C}$ and an initial testing speed of $0.015 \mathrm{inch} / \mathrm{minute}$, no indication of brittle failure was observed on the load-platen displacement curve. The test was continued at the original testing speed for approximately 10 minutes past the point where failure should have occurred. At this time it was decided to load the specimen to 100,000 pounds at a testing speed of roughly $1 / 2$ inch/minute. After this loading the specimen had increased 300 per cent in area and decreased 75.8 per cent in height, Figure 34. Note the radial cracking at the periphery, and large radial crack extending almost to the center of the disk. To gain further information on this result a similar test was conducted with specimen E-1. This time an indication of brittle failure was obtained at 15,200 pound load or 118,400 psi. The testing speed was then increased to $1 / 2 \mathrm{inch} / \mathrm{minute}$ and loading was continued to 100,000 pounds. The flattened specimen E-1 is similar in appearance and dimensions to specimen $\mathrm{D}-5$, Figure 34 。

Figures 35, 36, 37, 38 and 39 illustrate the results of a metallographic examination of a sample from flattened specimen $\mathrm{D}-5$. The extensive peripheral cracking present is illustrated in Figures 35 and 36. Toward the center of the disk, however, little cracking was apparent, Figure 37. Figures 38 and 39 illustrate the variation in grain structure 
across the 0.18 inch thickness of the disk. Note the elongation of grains in the direction of flow.

The above experiment indicates that it is possible to appreciably compress plutonium at fairly high alpha temperatures without excessive fragmentation, especially toward the interior of the specimen. Thus it may be possible to accomplish limited dimensional sizing operations without fracture in the alpha phase.

Since a high degree of plasticity is present in the beta, gamma and delta phases ultimate strength data could not be obtained. Yield strength values in the beta and gamma phases decrease with increasing temperature. Referring to Figure 33, the beta phase yield strength is decreased 70 per cent as the temperature increases from $130 \mathrm{C}$ to $190 \mathrm{C}$, while in the gamma phase the yield strength decreases 30 per cent over the 230 to $300 \mathrm{C}$ temperature range. The yield strength in the delta phase at $330 \mathrm{C}$ was the lowest of all temperatures studied.

For the beta, gamma and delta phases an indication of the effect of metal quality, i.e., impurity content and density, can be obtained from Figure 40 and Tables IX and X. In general, the higher quality metal, indicated by a higher density and a lower impurity content, has slightly lower yield strengths over the range of testing temperatures studied. No explanation can be offered for the apparent exception to this observation at $300 \mathrm{C}$.

\section{Formability Studies}

In the beta, gamma and delta phases a measure of plasticity or formability was obtained by loading the test specimens to 100,000 pounds at approximately $1 / 2 \mathrm{inch} /$ minute after the yield strength had been obtained at the normal speed of $0.015 \mathrm{inch} / \mathrm{minute}$. Decrease in length and increase in area data were determined as measures of formability, Figures 41, 42 and Tables IX and X. It can be seen that formability increases rapidly as the test temperature is increased through the beta. gamma and delta phases, the delta phase being the most formable. 
To determine the effect of loading to 100,000 pounds on microstructure, a series of metallographic samples were selected from the flattened compression specimens. In the beta phase, a number of cracks had formed on the surfaces where the compressive load was being applied, Figure 43. All inclusions were strung out in the direction of flow, perpendicular to the compression direction, Figures 44 and 45. The effect of the 100,000 pound beta compression on resultant alpha grain structure is illustrated in Figures 46 and 47. In Figure 46 the non-uniform nature of the grain structure is apparent, the average grain size is $0.012 \mathrm{~mm}$. An area containing columnar grains is illustrated in Figure 47. The axes of the columnar grains are parallel to the compression direction and perpendicular to the direction of metal flow during compression. A possible explanation for the columnar grain formation was presented in the tensile portion of this paper.

Compression to 100,000 pounds in the gamma phase also produced surface cracks similar to those produced in beta phase compression. In addition, interior cracks were produced which were aligned in the direction of flow during compression, Figure 48. Similar to the influence of beta forming on alpha grain structure, some areas of the gamma compressed specimens had a columnar grain structure like that illustrated in Figure 47. In addition, a columnar grain structure is present in some areas at the compression surface of the flattened specimen, Figure 49. Grain sizes ranged from 0.033 to $0.070 \mathrm{~mm}$ over the flattened section.

In the delta phase, at $330 \mathrm{C}$, compression to 100,000 pounds resulted in a number of large cracks aligned in the direction of flow, Figure 50. The alpha grain structure resulting from delta compression is uniform and has an average grain size of $0.0089 \mathrm{~mm}$ with no preferential grain alignment, Figure 51 .

In summary of the above metallographic data:

a. beta forming results in a few cracks at the compression surfaces; the grain structure is non-uniform with columnar areas.

b. gamma forming results in interior cracking in addition to 
cracks at compression surfaces; again the grain structure is non uniform, with columnar grains at the compression sur faces and in scattered areas over the flattened section.

c. delta forming results in severe interior cracking; the grain structure is uniform and very fine.

It must be remembered that some of the effects observed above are pos * sibly the result of cooling through the appropriate transformations after forming.

\section{Effect of Testing Speed}

For the alpha phase, Figures 52, 53 and Table XI illustrate that testing speed has the same general effect on the ultimate and yield strength in compression as was observed in tension. As the testing speed is increased from $0.002 \mathrm{inch} / \mathrm{minute}$ to $1.00 \mathrm{inch} / \mathrm{minute}$ the strength values increase to a maximum and then decrease. As discussed in the section on tensile properties, this is probably the result of a competition of strain hardening and notch sensitivity factors.

In the beta phase, the yield strength increases almost linearly with increasing testing speed, Figure 53. Over the range of testing speeds studied the increase in yield strength is 350 per cent. For the gamma phase, a 70 per cent increase in yield strength from 2,620 to 4,500 psi is observed. Comparison with tensile data, indicates that for the beta and gamma phases the effect of testing speed on yield strength results is about the same for both tension and compression testing.

A further indication of the effect of metal quality on yield strength can be determined from data obtained at various testing speeds in the beta. phase for low and high quality metal, Figure 54 and Table XII. At testing speeds ranging from 0.002 to 1.0 inch/minute, the yield strength for high quality plutonium is 20 to 30 per cent lower than that for low quality plutonium.

The effect of testing speed and test temperature on total plastic deformation of alpha phase plutonium prior to fracture is illustrated in Figures 55, 56 and Table XIII. For all testing speeds, as test 
temperatures increase the amount of plastic defarmation increases to a maximum and then decreases, Figure 55. This maximum occurs at $70 \mathrm{C}$ for all testing speeds except 0.002 inch/minute where the maximum occurs at $30 \mathrm{C}$.

At -30 and $30 \mathrm{C}$, Figure 56, the effect of increasing testing speed is to decrease the total plastic deformation, which is generally the case for most metals. However, at the 70 and $100 \mathrm{C}$ test temperatures, the total plastic deformation increases up to the $0.060 \mathrm{inch} / \mathrm{minute}$ testing speed and then decreases with increasing testing speed. The initial increase is probably the result of recovery which would have less effect as testing speed increases.

The effect of testing speed on the deformation characteristics of the specimens tested at 70 and $110 \mathrm{C}$ is illustrated in Figures 57 and 58. Note that the 0.060 and $0,250 \mathrm{inch} / \mathrm{minute}$ speeds produce similar failures, i.e. barreling followed by a shear fracture. For the 1.0 inch/minute testing speed, the typical shear failure is obtained, however the barreling has been replaced by a localized bulge. This occurs for both 70 and $110 \mathrm{C}$ temperatures at the 1.0 inch/minute testing speed, Figure 58, and is not observed at lower temperatures at this speed. This phenomenon is not unusual since it is known that as the rate of plastic deformation increases deformation in the specimen becomes more localized. Thus bulging is produced at the high testing speeds during compression testing. Bulging is not observed at the lower test temperatures and high test speed because fracture occurs before extensive localized plastic deformation becomes apparent.

\section{CREEP TESTING}

\section{Experimental Material and Testing Techniques}

Densities and total impurity contents for the creep specimens tested are presented in Table XIV。 The density of casting heat $18-10-12$, $19.43 \mathrm{~g} / \mathrm{cc}$, is at the low end of the density range of specimens discussed earlier in the paper, however, the total impurity contents are about average. 


\section{$\underline{\text { Results and Discussion }}$}

Impact energy values ranging from 1.3 to 4.8 foot-pounds, with an average of 2.6 foot-pounds were obtained, Table XV. A typical brittle fracture resulted in each case. Seven of the specimens tested failed at both ends of the gage length, Figure 61, while one specimen failed only at one end of the gage length. The cause for failure at the ends of the gage length can probably be attributed to non-axiality of loading, since inspection of the radii at either end of the gage length showed that no uneven junctures were present.

\section{TORSION TESTING}

The experimental material for the torsion specimens was also comparable to that used in the tensile property study. Five tubular torsion specimens, with 0.250-inch inside diameter, 0.375-inch outside diameter and 2.50-inch gage length were fabricated. Testing was done at $30 \mathrm{C}$ in a plastic encased fixture, Figure 62, on a non-glove-boxed Tinius Olsen Torsion Testing Machine. Four of the five specimens fractured brittlely at ultimate shear strengths of $46,400,54,700,53,700$ and 57, 800 psi, Figure 63; the remaining specimen broke at a defect. Although accurate angle of twist data could not be obtained during testing, it was indicated that the stress-strain curve in torsion was quite similar to that for tension. 


\section{BETA, GAMMA AND DELTA PHASE EXTRUSION}

\section{Experimental Material and Procedure}

Billets 18-12-3C, 18-12-4A and 19-1-4 were cast in vacuo into $\mathrm{MgO}$ coated graphite molds. Pouring temperature was $900 \mathrm{C}$ and the mold was heated to $300 \mathrm{C}$ prior to pouring. The billets were machined to size in preparation for extrusion. Billets $19-6-3$ and $19-6-4$ were poured at $740 \mathrm{C}$ into a copper mold which had been heated to $550 \mathrm{C}$. These billets were cast to size and not machined prior to extrusion. Table XVI contains the chemical impurity and density data.

The extrusions were performed on a Baldwin Universal Testing Machine equipped with a glove box and a fixture which permitted extrusions at forces up to 50 tons. Two different types of extrusion dies were used, a shear die and a streamline flow die, Figure 64. All billets were extruded at a ram speed of 1.5 inches per minute at a 9 to 1 extrusion ratio. The billets were heated to the extrusion temperature in a peanut oil bath. No lubricant was used during extrusion and the atmosphere in the glove box was air.

\section{Results and Discussion}

The extrusion pressures and constants obtained for the beta, gamma and delta phases, Table XVII, reflect the elevated temperature tensile strength data previously obtained. The tensile strength was found to decrease in each higher temperature phase, which is also the case for the extrusion pressures and constants. The force versus platen displacement curves obtained during extrusion are comparable to those obtained for other metals.

During cooling of the extruded rods to room temperature, it was determined that decreases in diameter of $3,6,4.5$ and 7.8 per cent had occurred for extrusion in the beta, gamma and delta phases respectively. The over-all surface quality of the extruded rods was good, Figure 65. Note that bonding did not occur at the dead metal-flowing metal interface during the gamma extrusions with the shear die. 
Metallographic specimens were taken at several positions along the length of extruded rods 18-12-4A, 18-12-3C and 19-1-4. Extrusion produced much the same effect on the microstructure as observed on the elongated tensile specimens. Microcracks, $\mathrm{Pu}-\mathrm{Pu} \mathrm{u}_{6} \mathrm{Fe}$ eutectic and $\mathrm{PuN}$ inclusions were all elongated in the extrusion direction.

Extruded rods 18-12-4A and 19-1-4 contained an unusually large number of PuN inclusions which is attributed to inadequate slagging action during casting. It is felt that if sufficient time is allowed between pouring and solidification, the PuN inclusions will float to the top of the meit where they can be adequately cropped after solidification. The top of cast billet 18-12-4A exhibited the interesting PuN configurations illustrated in Figure 66. A PuN cluster elongated in the extrusion direction is illustrated in Figure 67.

While examining a metallographic section taken along the extrusion direction of rod 18-12-4A it was determined that not all the microcracks were strung out in the extrusion direction. A number of microcracks were randomly oriented in the microstructure, Figure 68. This observation indicates that microcracking occurs during the beta to alpha transformation.

A wide variety of grain structure and grain size were present along the length of the beta extruded rod. Structures ranged from columnar near the rod periphery, Figure 69, to banded, alternate layers of fine and coarse grains throughout the cross section of the rod, Figures 70 and 71. In addition, a columnar alignment of grains similar to that observed in specimens tensile tested in the beta phase was observed to radiate from microcracks, Figure 72. There was no apparent preferential alignment or elongation of grains in the extrusion direction. Grain sizes throughout the rod ranged from 0.0062 to $0.025 \mathrm{~mm}$. For comparison, the original as-cast structure, grain size $0.023 \mathrm{~mm}$, is illustrated in Figure 73 .

In the gamma extruded rods, variations were also present in the grain structure although not as marked as in the beta extruded rod. Columnar grains arranged in a swirly pattern were common throughout the cross section, Figure 74, as were randomly oriented grains similar 
to those in Figure 73. As in the beta extruded rod, the alpha grains were not elongated in the extrusion direction, Figure 75. As indicated earlier. the over-all surface finish of the extruded rods was good, however during the metallographic examination a few blisters were observed on rods 18-12-4A and 18-12-3C; a typical blister is illustrated in Figure 76 .

Tension, compression and hardness data were obtained on the rods extruded from billets $18-12-3 \mathrm{C}, 18-12-4 \mathrm{~A}$ and $19-1-4$. Average values for these properties are compared to asmcast data in Table XVIII. Except for the ultimate strength of the beta extruded rod, the general effect of extrusion was to increase both ultimate and yield strengths by roughly 10 per cent. The modulus of elasticity appears to be increased slightly, possibly because of orientation effects. The low ultimate strength in the beta extruded rod can be attributed to the relatively poor quality of the initial billet which became apparent during the metallographic examination.

The ultimate strength in compression may have been slightly lowered by extrusion. The poor quality of billet 18-12-4A was reflected in the compression properties of the beta extruded rod. Only one of the four compression specimens from this rod did not fail at a defect. Poor quality cast billets result in the presence of deleterious stringers of inclusions in the extruded rod which act as stress raisers during compression causing premature failure.

Density and hardness data from the extruded rods are comparable to as - cast plutonium. None of the properties studied seemed to vary appreciably along the length of the extruded rods.

\section{ACKNOWLEDGEMENT}

The many and varied operations involved in preparing specimens for the studies described in this paper were ably conducted by J。 C. Duncan, C. C. Bentley, I. M. Glover, J。 P. Keiser and W. D. Leahy。 Their competent assistance throughout the course of this work was greatly appreciated. 


\section{BIBLIOGRAPHY}

1. Coffinberry, A. S. and M. B. Waldron

The Physical Metallurgy of Plutonium

Progress in Nuclear Energy, 1956, 1, Series V, p. 399.

2. Gardner, H. R., C. H. Bloomster and J. M. Jefferes

The Tensile Properties of Pure Plutonium and Some Aluminum-

Plutonium Alloys

Second Int'l Conference on Peaceful Uses of Atomic Energy, 15/P/1081.

3. Sinnott, M. J., W. R. Kiessel and J. C. Tobin

Final Report on Development of Apparatus and Methods for

Measurement of Creep to Temperatures of $3500 \mathrm{~F}$

Part I, Project M781, University of Michigan, August 15, 1950.

4. Hill, J. B.

U. K. Newsletter No. 19

Metallurgy Division, A.E.R.E., 1960.

5. Davis, H. E., G. E. Troxell and C. T. Wiskocil

The Testing and Inspection of Engineering Materials

McGraw-Hill Book Co. 1941, 95-96.

6. Gardner, H. R. and J. M. Jefferes

The Tensile Properties of Pure Plutonium

HW-57130, August 6, 1958. 


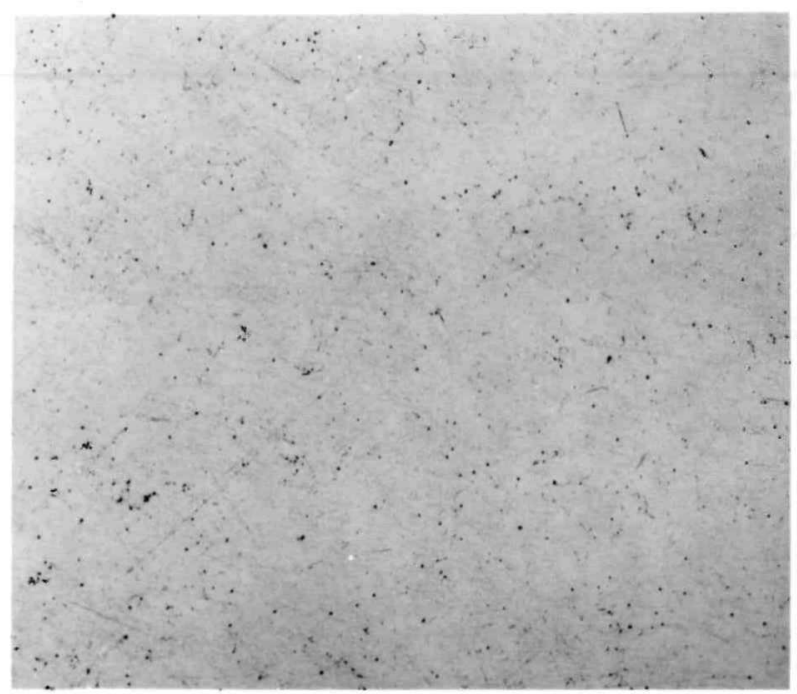

FIGURE 1

Typical Area, Casting Heat 19-6-4, Density $19.56 \mathrm{~g} / \mathrm{cc}$. Note Microcracking, $50 \mathrm{X}$.

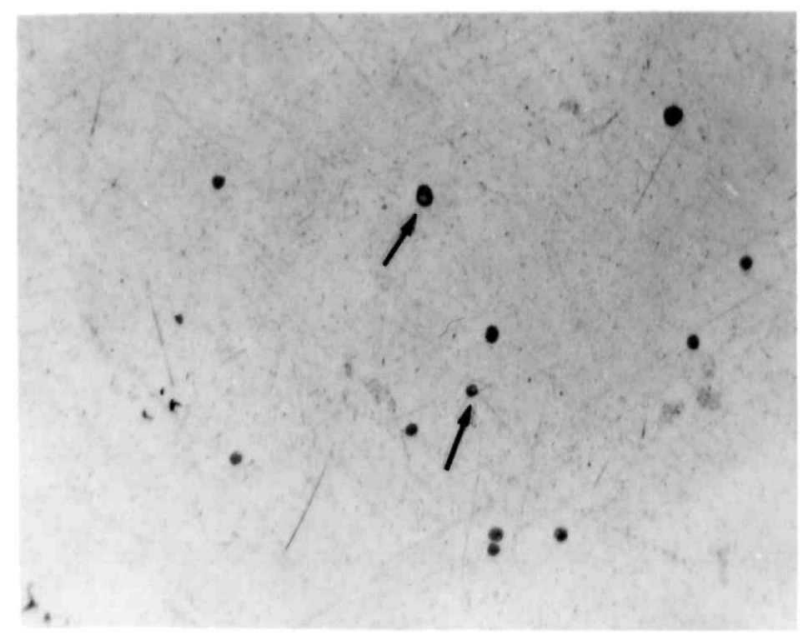

FIGURE 3

Same Sample as in Figure 1, Photographed at $250 \mathrm{X}$ to Show Spherical Unidentified Inclusions. Note that Some Appear to have a "Donut" Type Configuration, Arrow, $250 \mathrm{X}$.

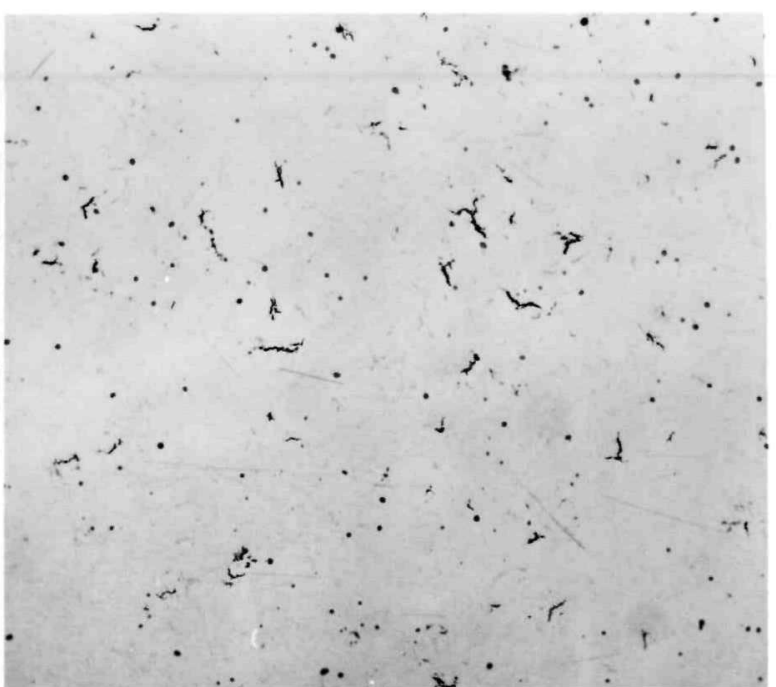

FIGURE 2

Typical Area, Casting Heat 18-16L, Density $19.47 \mathrm{~g} / \mathrm{cc}$. Note Larger Size Microcracks Than in Figure 1, 50X.

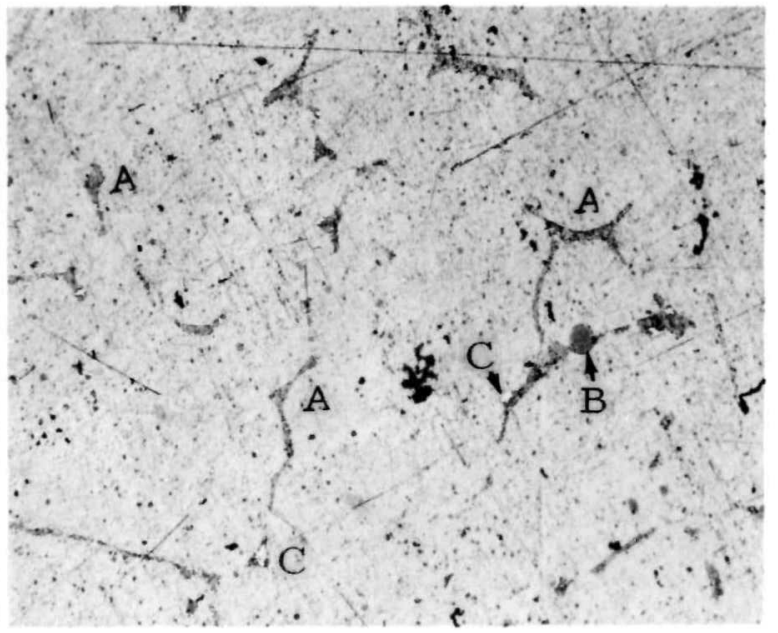

FIGURE 4

Typical Area for 19-2-1 and 19-2-2 Casting Heats, Average Density $19.43 \mathrm{~g} / \mathrm{cc}, 1250 \mathrm{ppm}$ Average $\mathrm{Fe}$ Content, Table V. $\mathrm{Pu}_{6} \mathrm{Fe}$ Eutectic (A), Unidentified Spherical Inclusions (B), and Unidentified White Particulate Inclusions Visible in Field (C). Note Absence of Microcracking, $250 X$. 


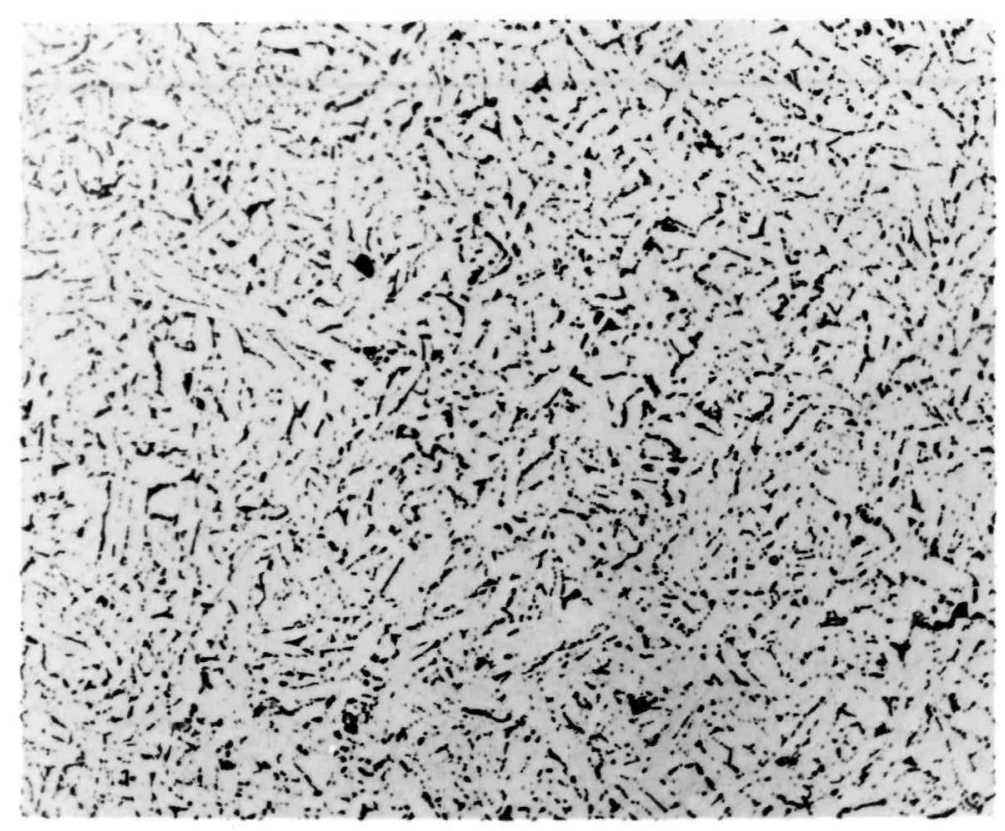

\section{FIGURE 5}

Typical Area for Casting Heat 19-11-2E, $\mathrm{Pu}_{6} \mathrm{Fe}$ Eutectic in Plutonium Matrix, Density $19.47 \mathrm{~g} / \mathrm{cc}, 1175 \mathrm{ppm}$ Fe. Grain Size of Eutectic Network $0.033 \mathrm{~mm}, 10$ Second Etch, 100X.

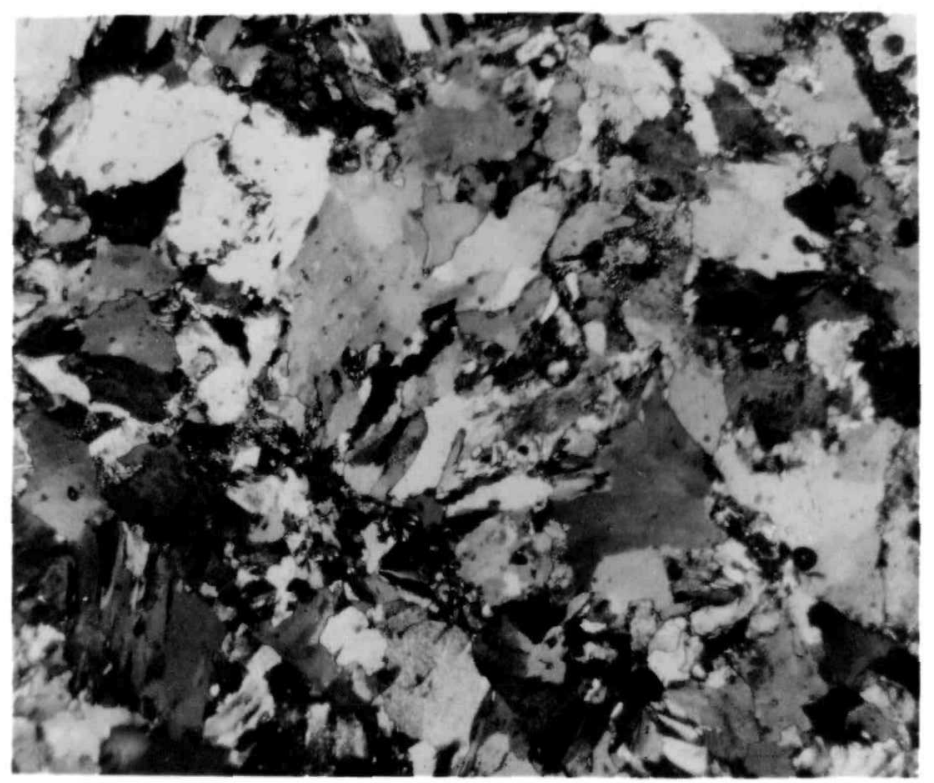

FIGURE 6

Specimen 19-7-2, Typical of Grain Structure in All As Cast Plutonium. Grain Size $0.047 \mathrm{~mm}, 250 \mathrm{X}$. 


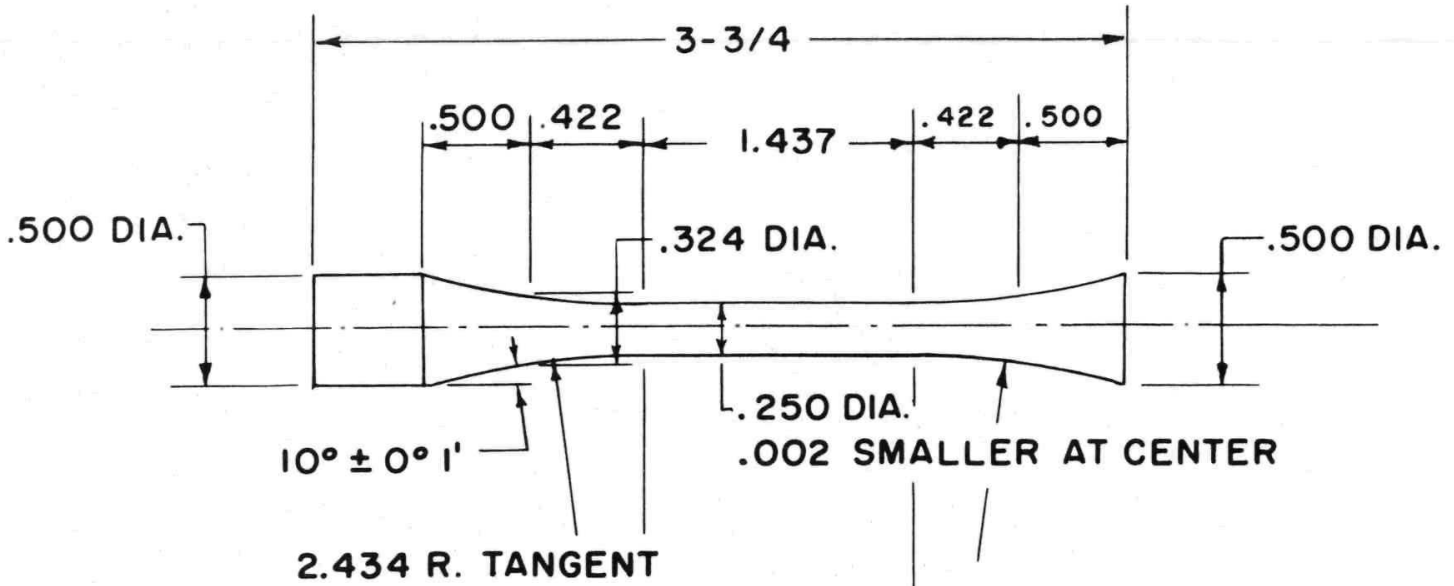
TO BOTH SURFACES

2.434 R. TANGENT TO BOTH SURFACES

FIGURE 7

Design for 0.250 inch Diameter Tensile Specimens

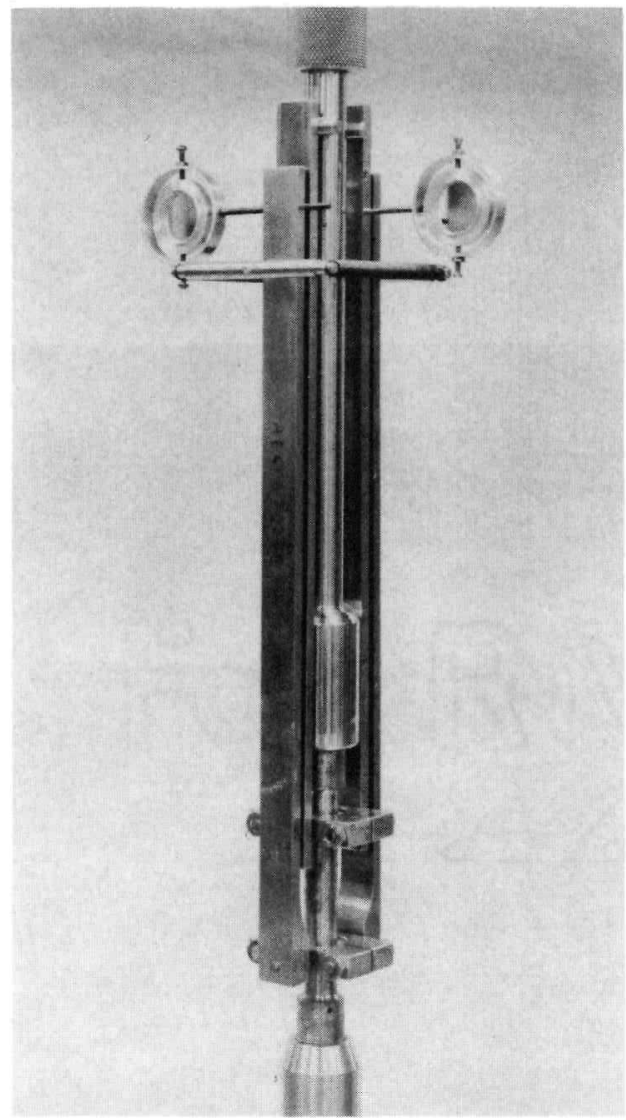

\section{FIGURE 8}

Martins Extensometer on 0.505 Inch Diameter Tensile Specimen, $1 / 4 \mathrm{X}$. 


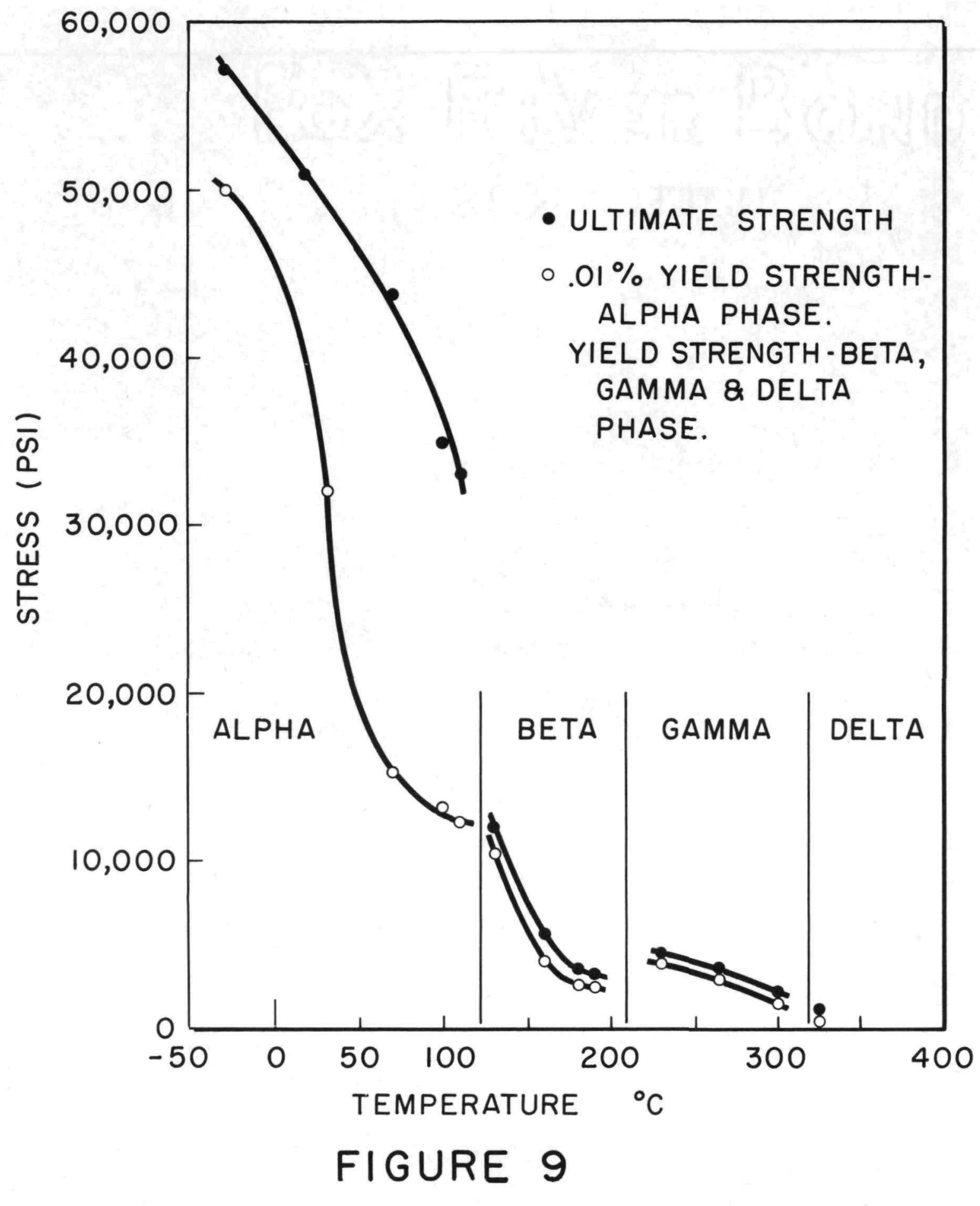

EFFECT OF TEMPERATURE ON TENSILE STRENGTH 


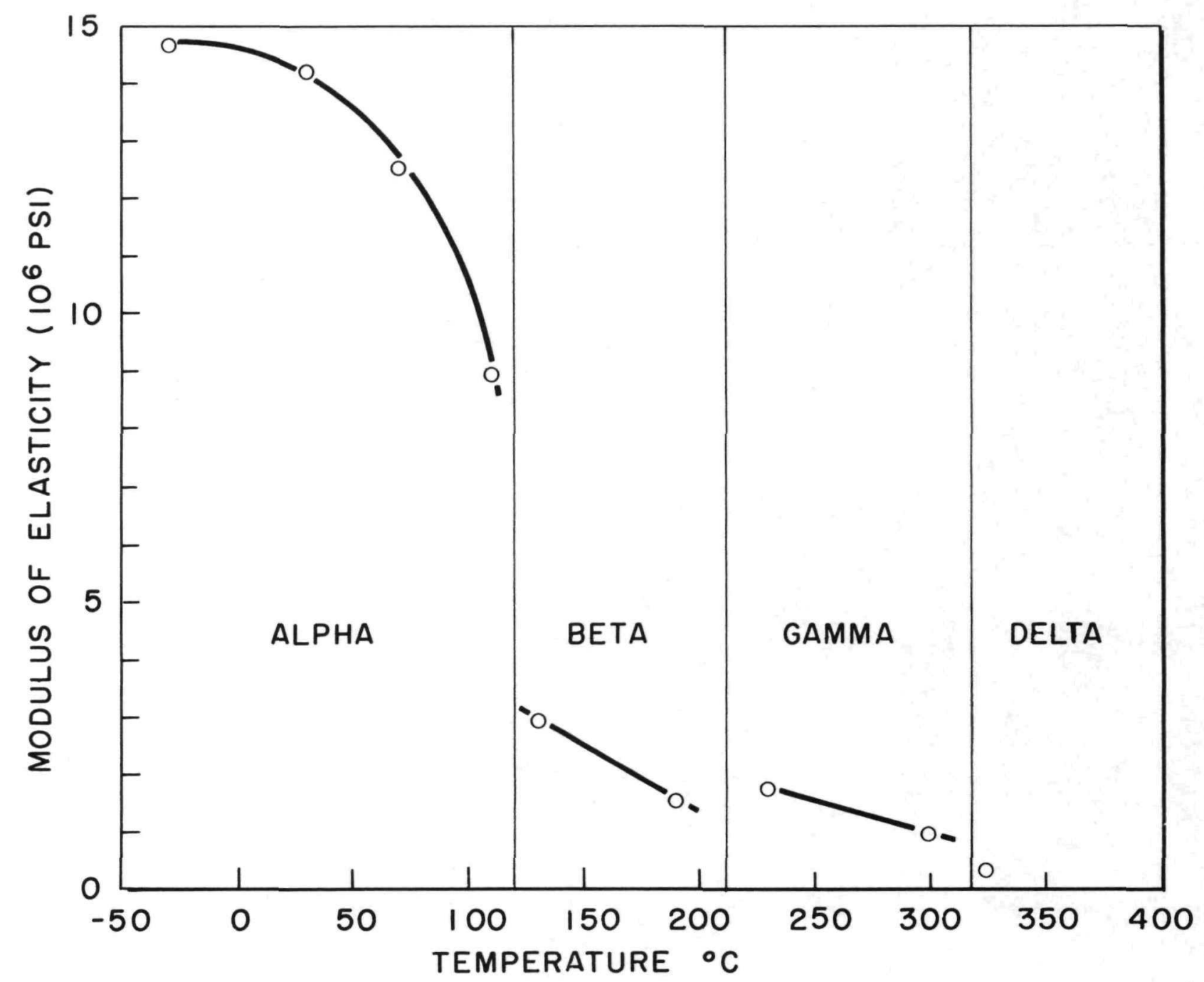

FIGURE 10 


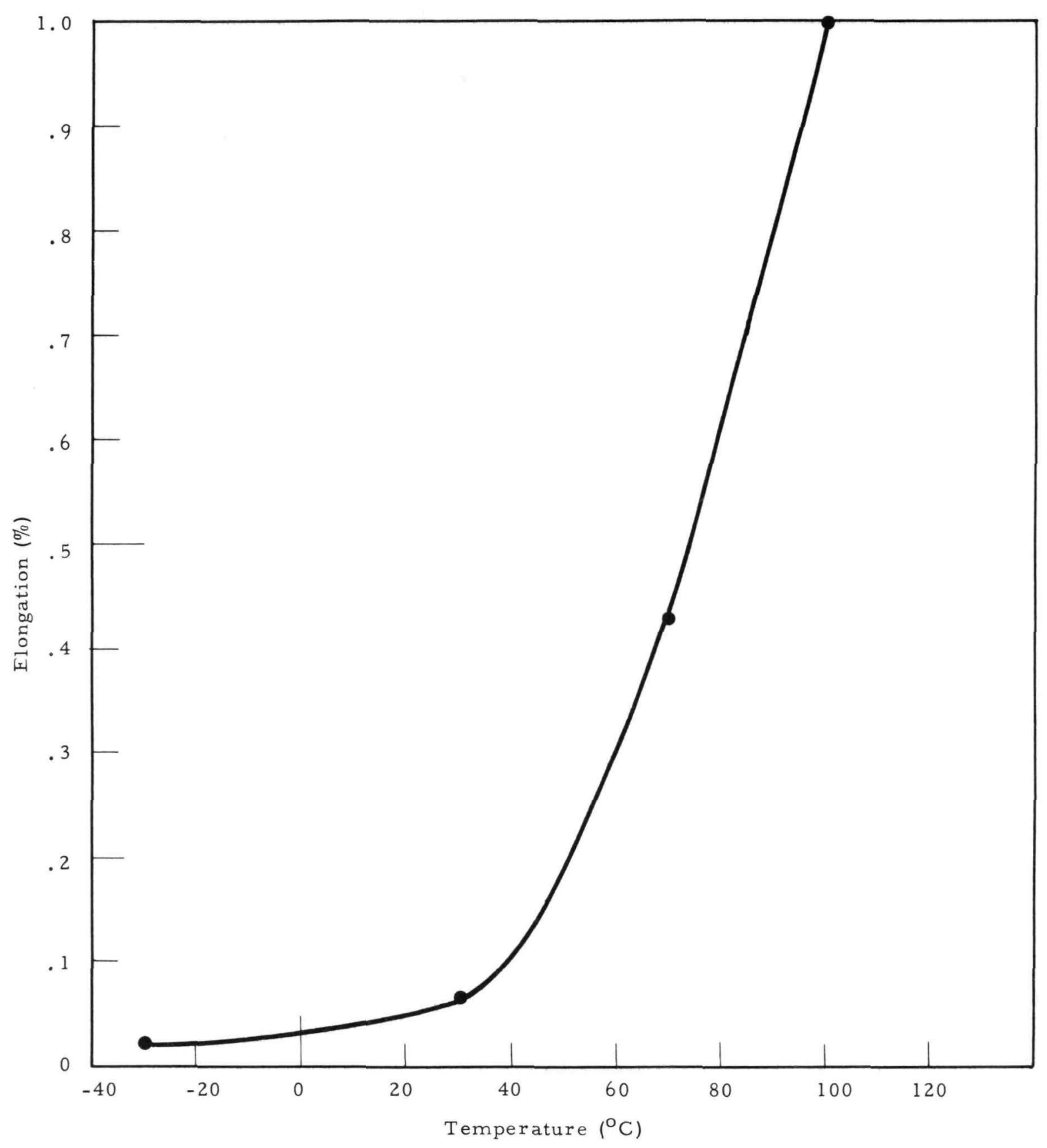

FIGURE 11

Effect of Test Temperature on Alpha Phase Elongation 


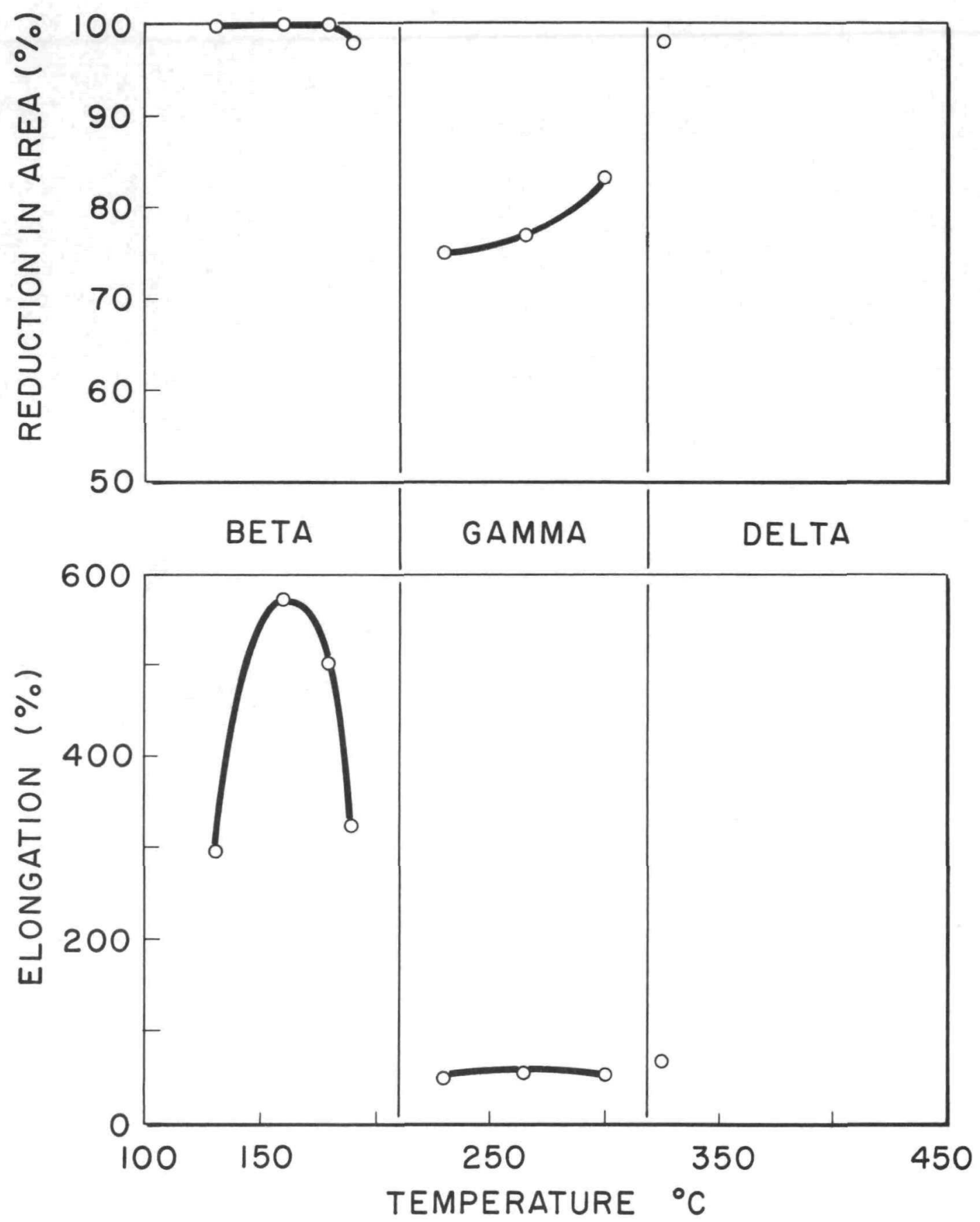

FIGURE 12

EFFECT OF TEMPERATURE ON DUCTILITY 


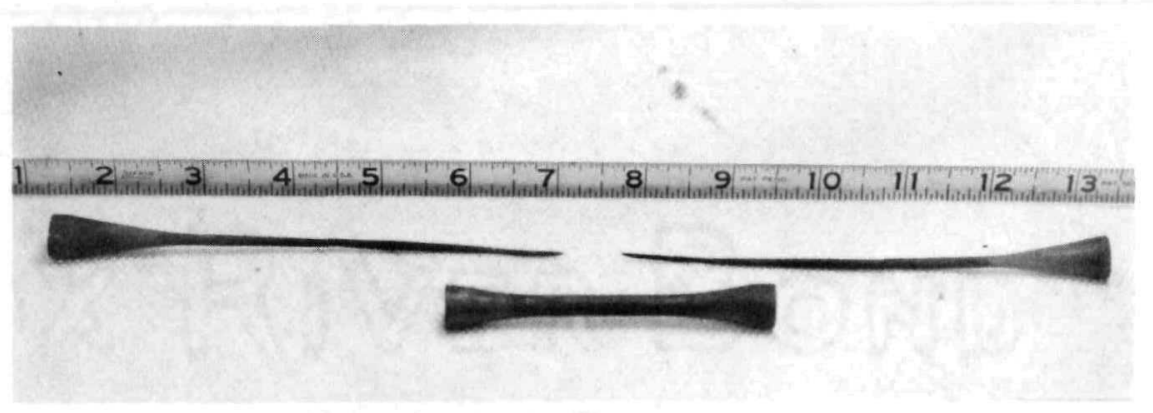

FIGURE 13

Beta Phase $-160^{\circ} \mathrm{C}, 0.015$ Inch/Minute.

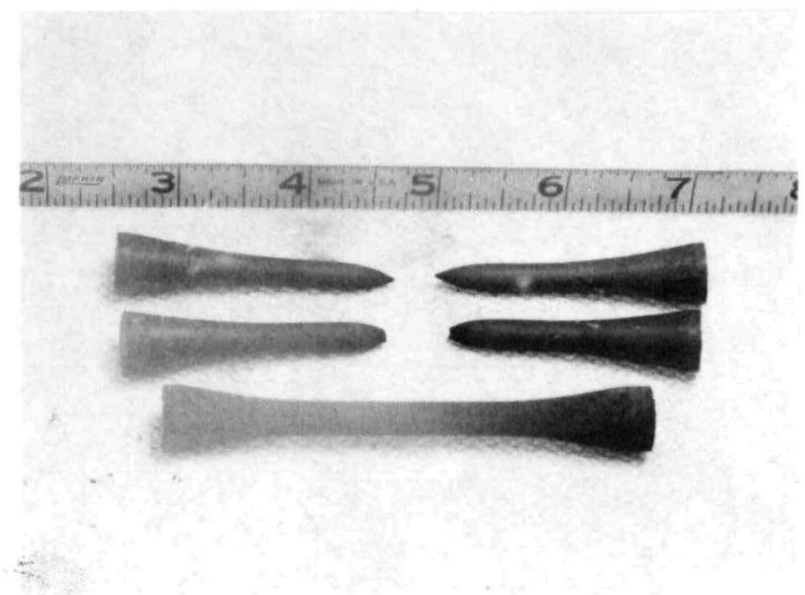

\section{FIGURE 14}

Gamma Phase $-265^{\circ} \mathrm{C}, 0.015$ Inch/Minute. Upper Specimen Contained $\mathrm{Pu}_{6} \mathrm{Fe}$ Eutectic, No Microcracks. Lower Specimen Contained Microcracks, No Pu6 Fe Eutectic.

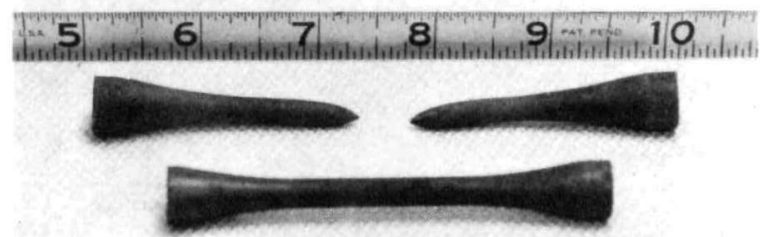

FIGURE 15

Delta Phase $-325^{\circ} \mathrm{C}, 0.015$ Inch/Minute. 


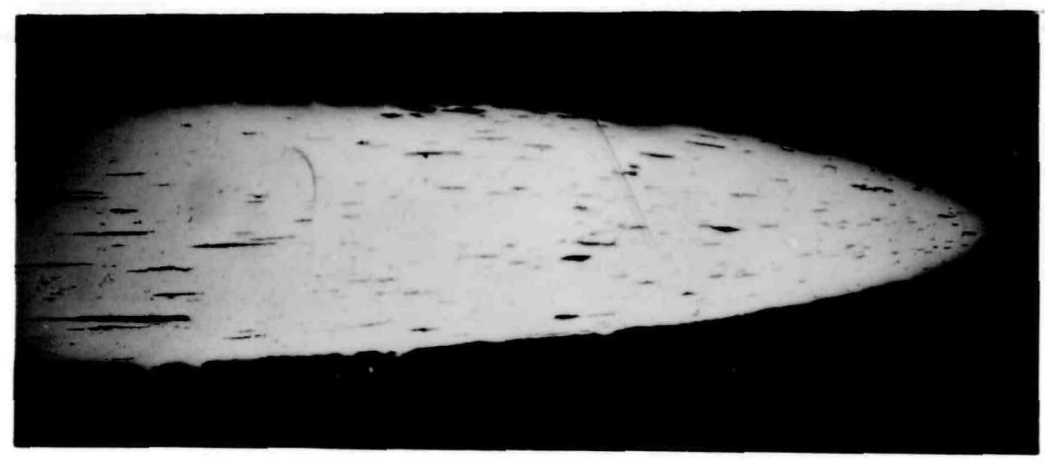

FIGURE 16

Typical Beta Phase Tensile Fracture, 1600C, Specimen 19-9-7C. Note Cracks Elongated in Direction of Loading, $20 \mathrm{X}$.

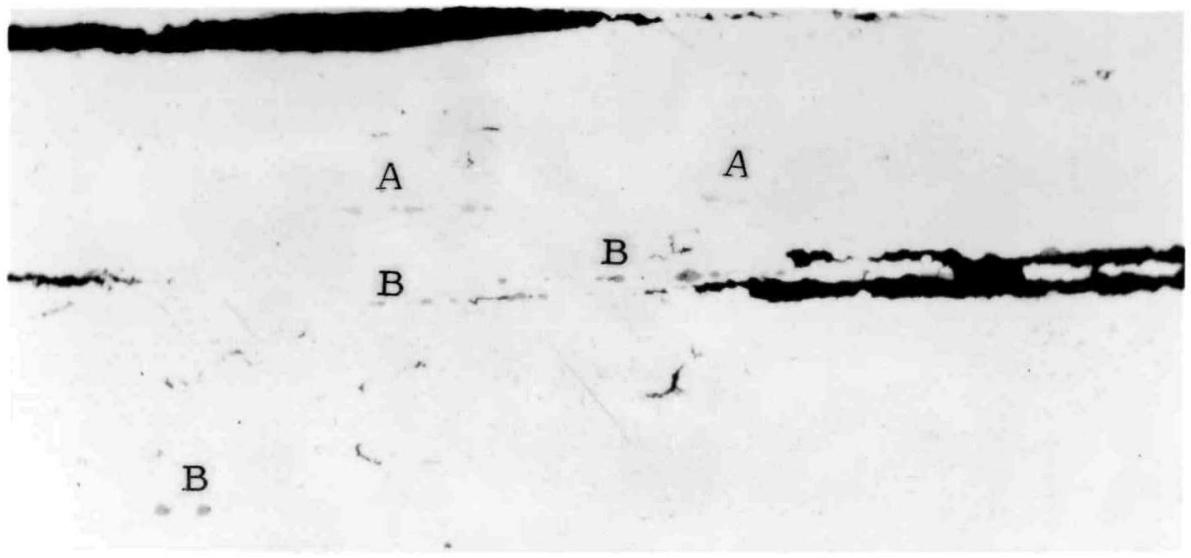

FIGURE 17

Area from Above Sample Illustrating, Elongated Cracks, $\mathrm{Pu}_{6}$ Fe Eutectic (A) and Unidentified Spherical Inclusions (B), $150 \mathrm{X}$.

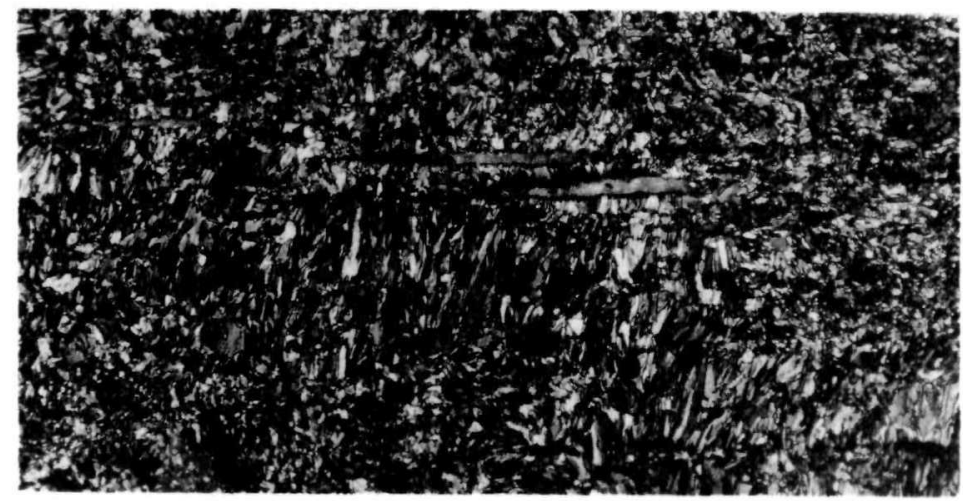

FIGURE 18

Grain Structure of Beta Phase Tested Specimen 19-9-7C, Note Columnar Grains Apparently Nucleated by Cracks or Inclusions. Average Grain Size $0.0089 \mathrm{~mm}$, As Cast Grain Size $0.060 \mathrm{~mm}, 100 \mathrm{X}$. 


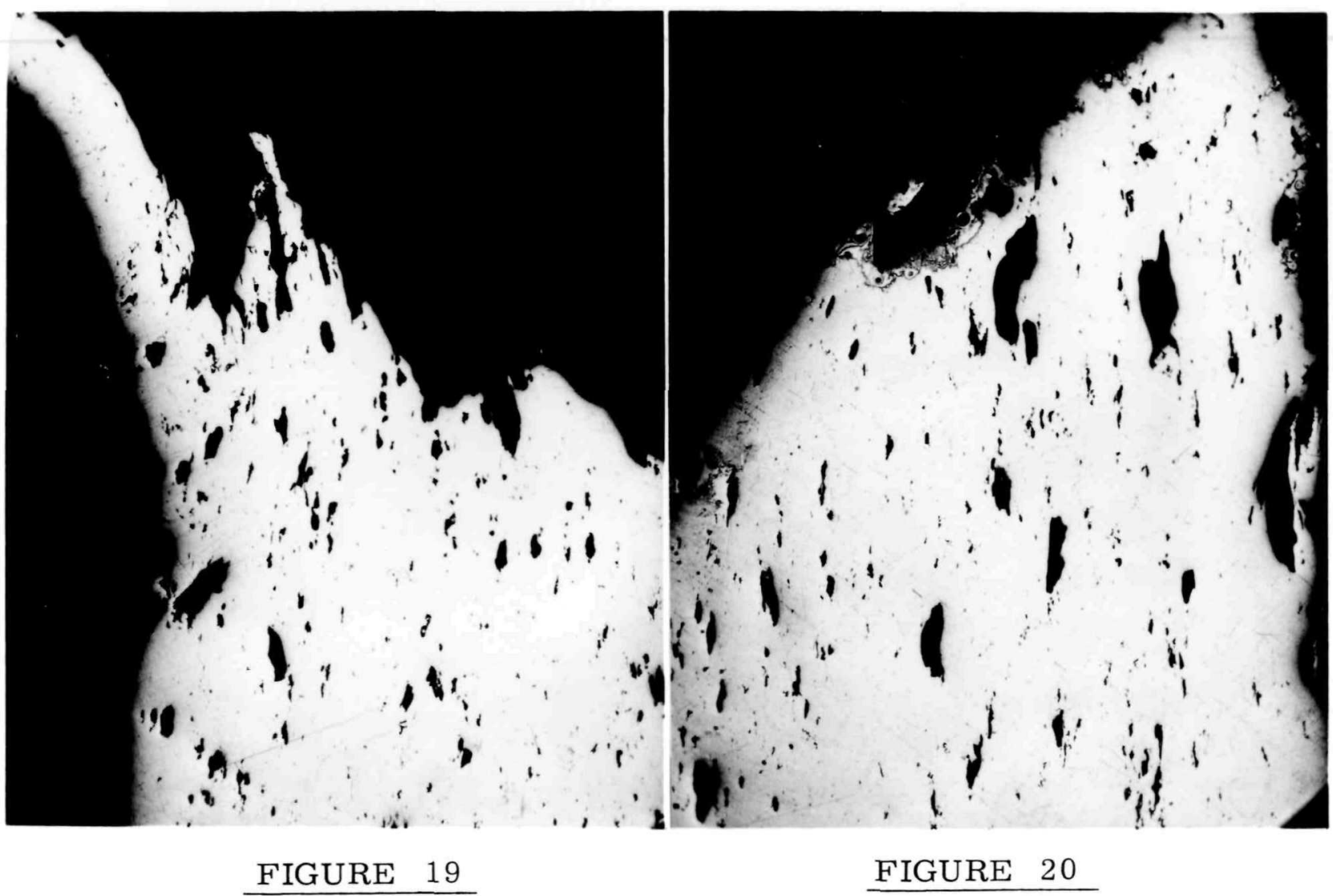

Specimen $19-5-6 \mathrm{H}, 44 \mathrm{X}$.

Specimen 19-9-8H, 44X.

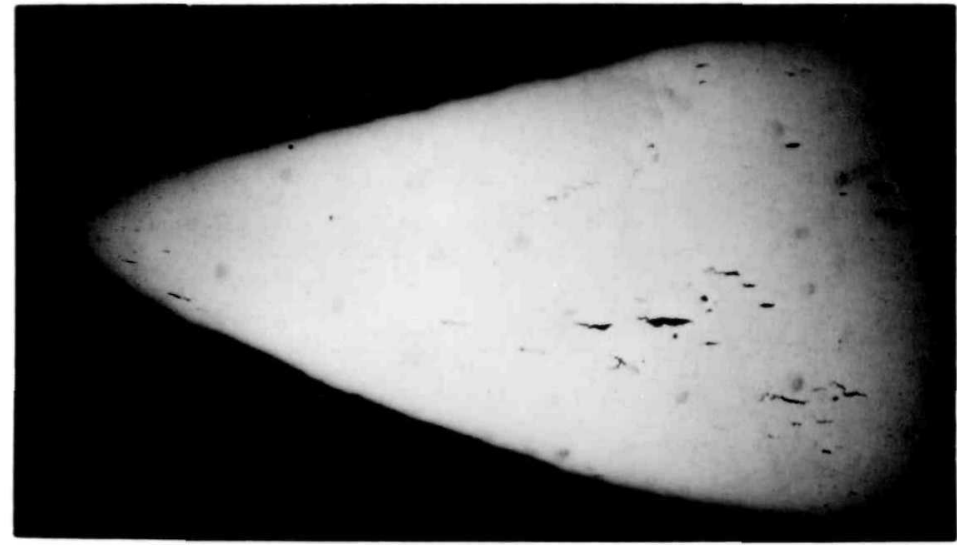

FIGURE 21

Specimen 19-11-3J, 20X.

The Above Figures Illustrate the Types of Fracture that Occurred During Gamma Phase Tensile Testing at $265^{\circ} \mathrm{C}$. The Reason for the Different Types is Believed to be a Function of the Degree of Microcracking Originally Present in the As Cast Structure. 


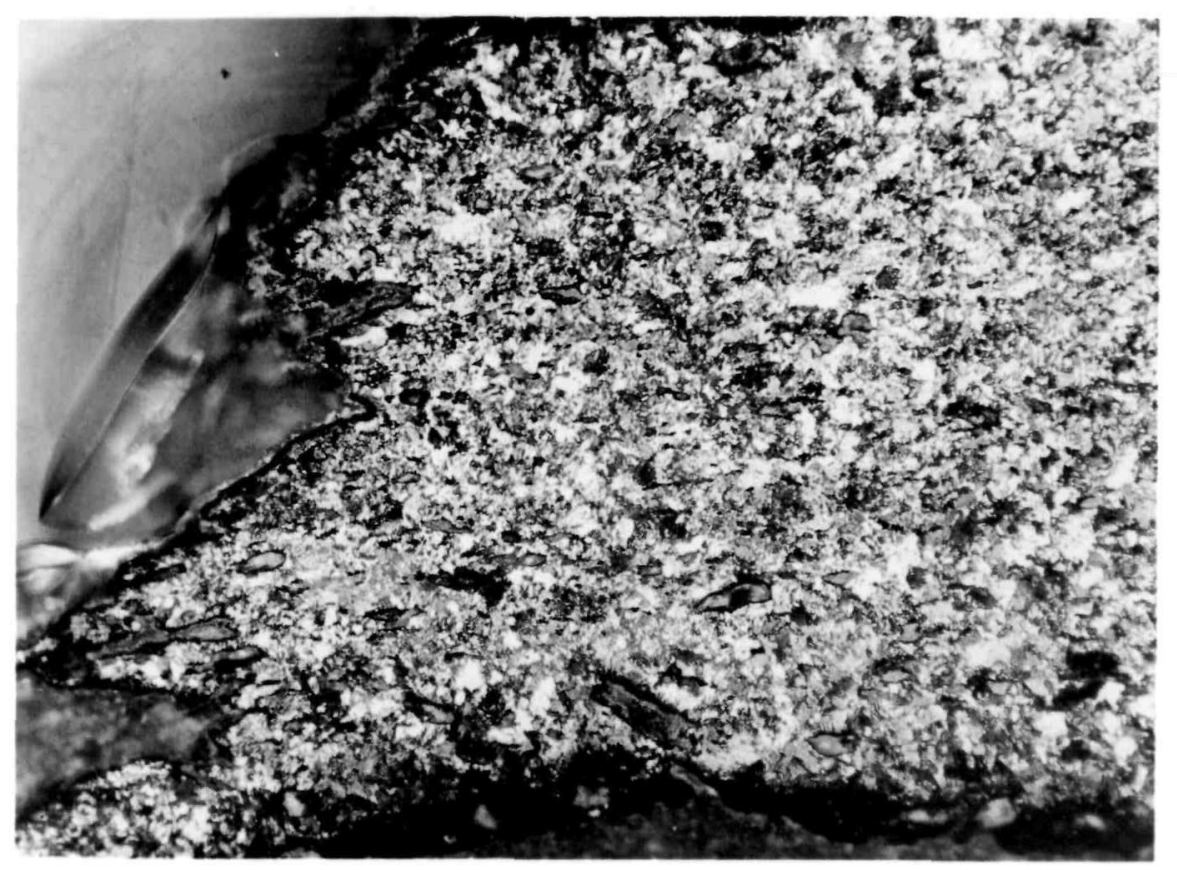

FIGURE 22

Same Area as in Figure 19 Illustrating Uniform Random Grain Structure. Grain Size $0.040 \mathrm{~mm}$, which is Essentially the Same as the As Cast Grain Size, 50X.

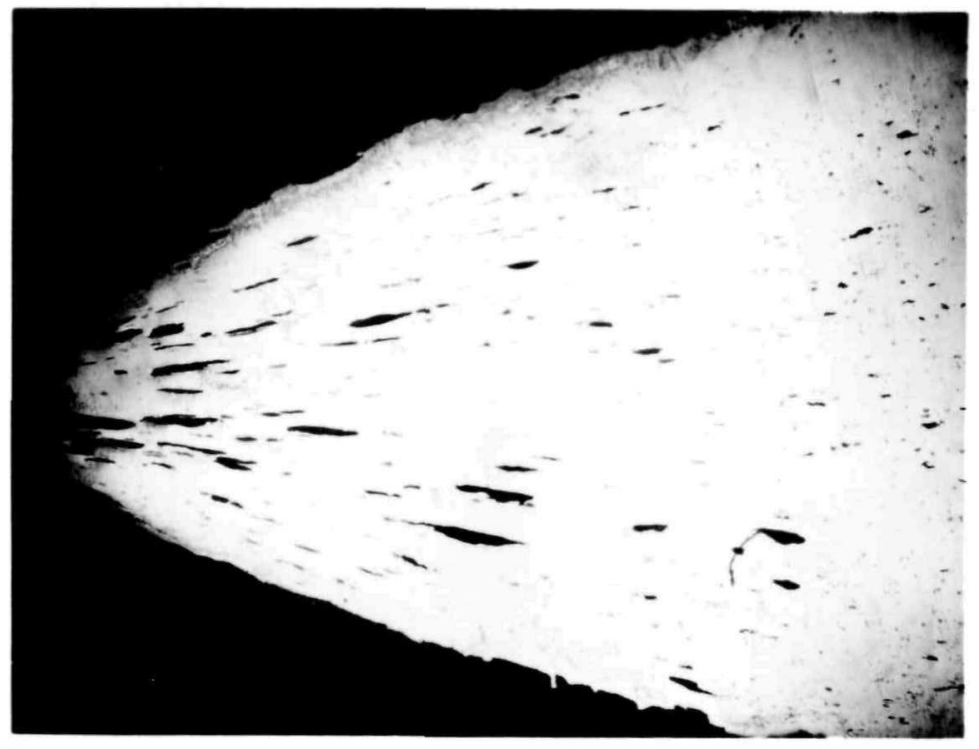

FIGURE 23

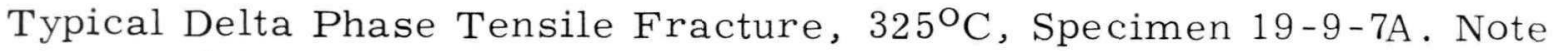
Elongated Cracks Along Loading Axis, $20 \mathrm{X}$. 


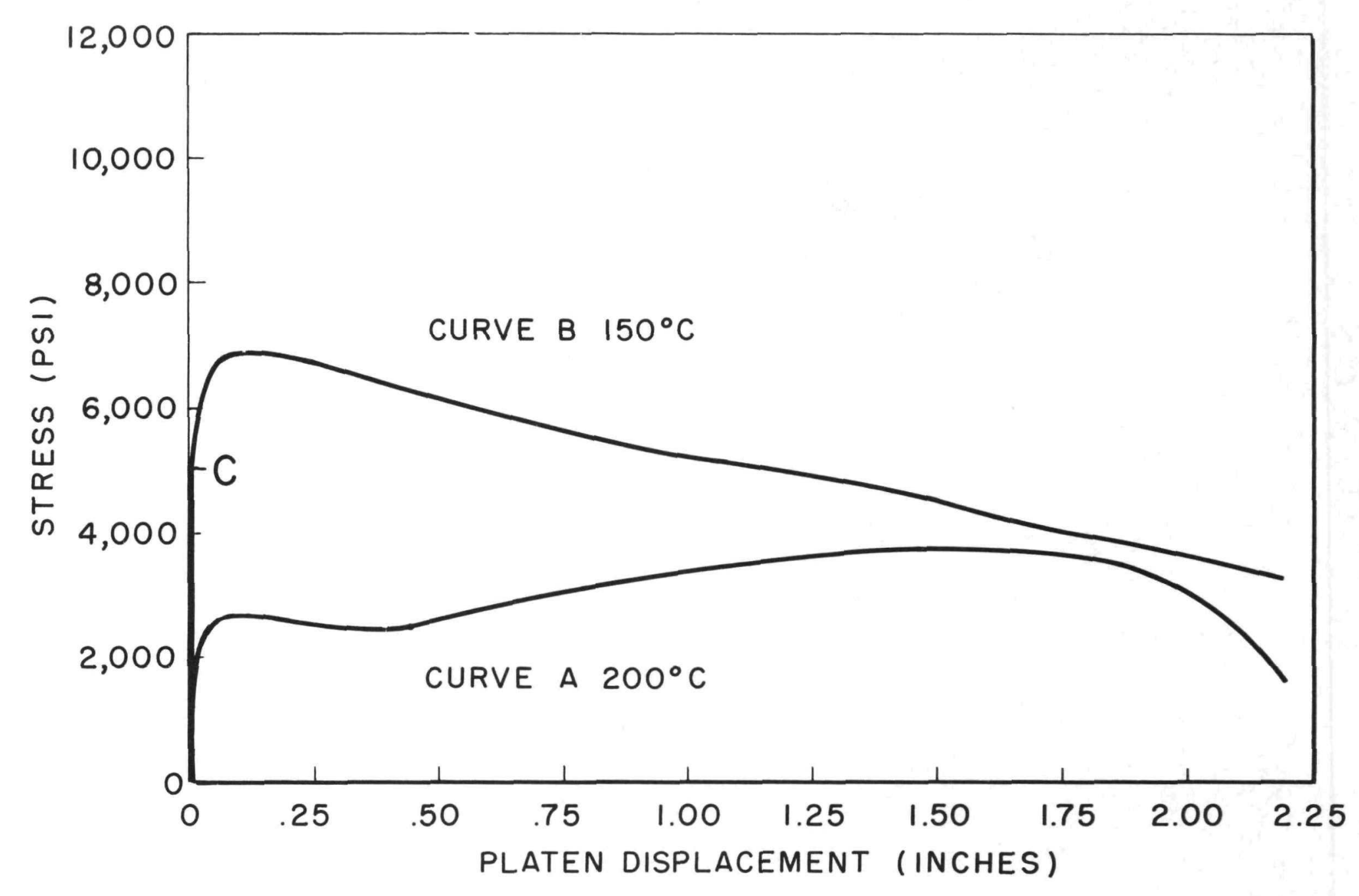

w.

FIGURE 24

STRESS - PLATEN DISPLACEMENT CURVES 


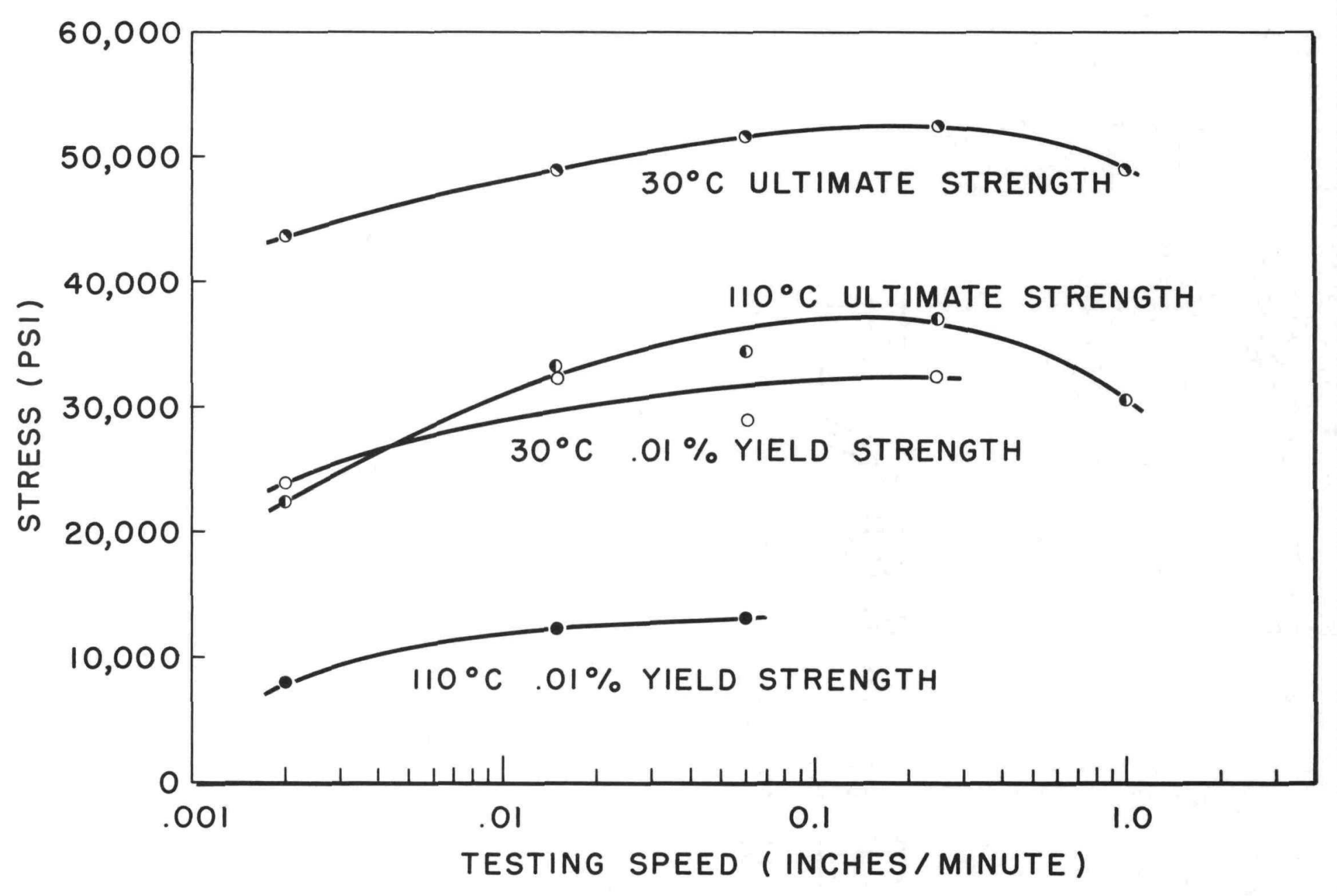

FIGURE 25

EFFECT OF TESTING SPEED ON ALPHA PHASE TENSILE STRENGTH 


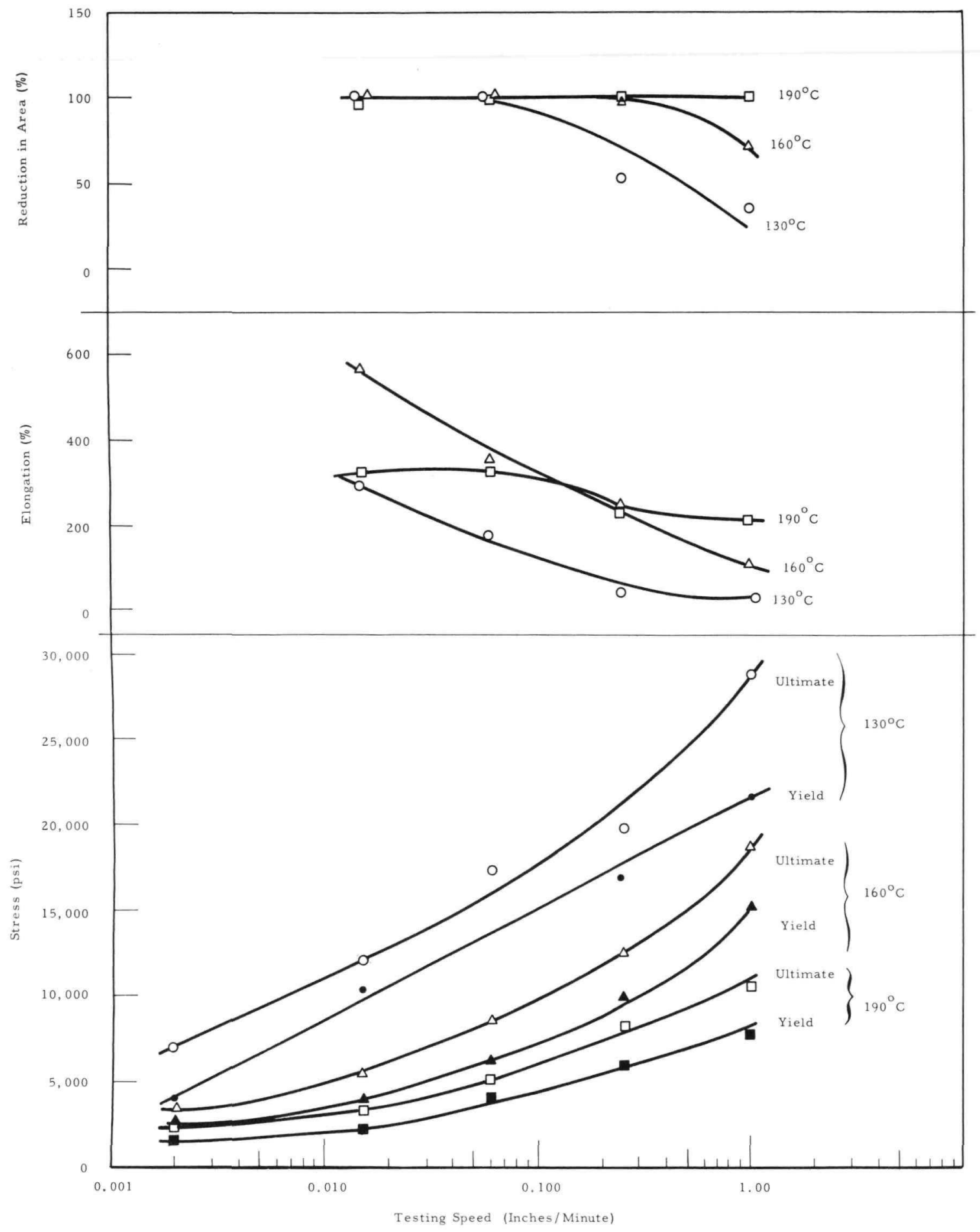

FIGURE 26

Effect of Testing Speed on Beta Phase Properties at 130, 160 and $190 \mathrm{C}$ 


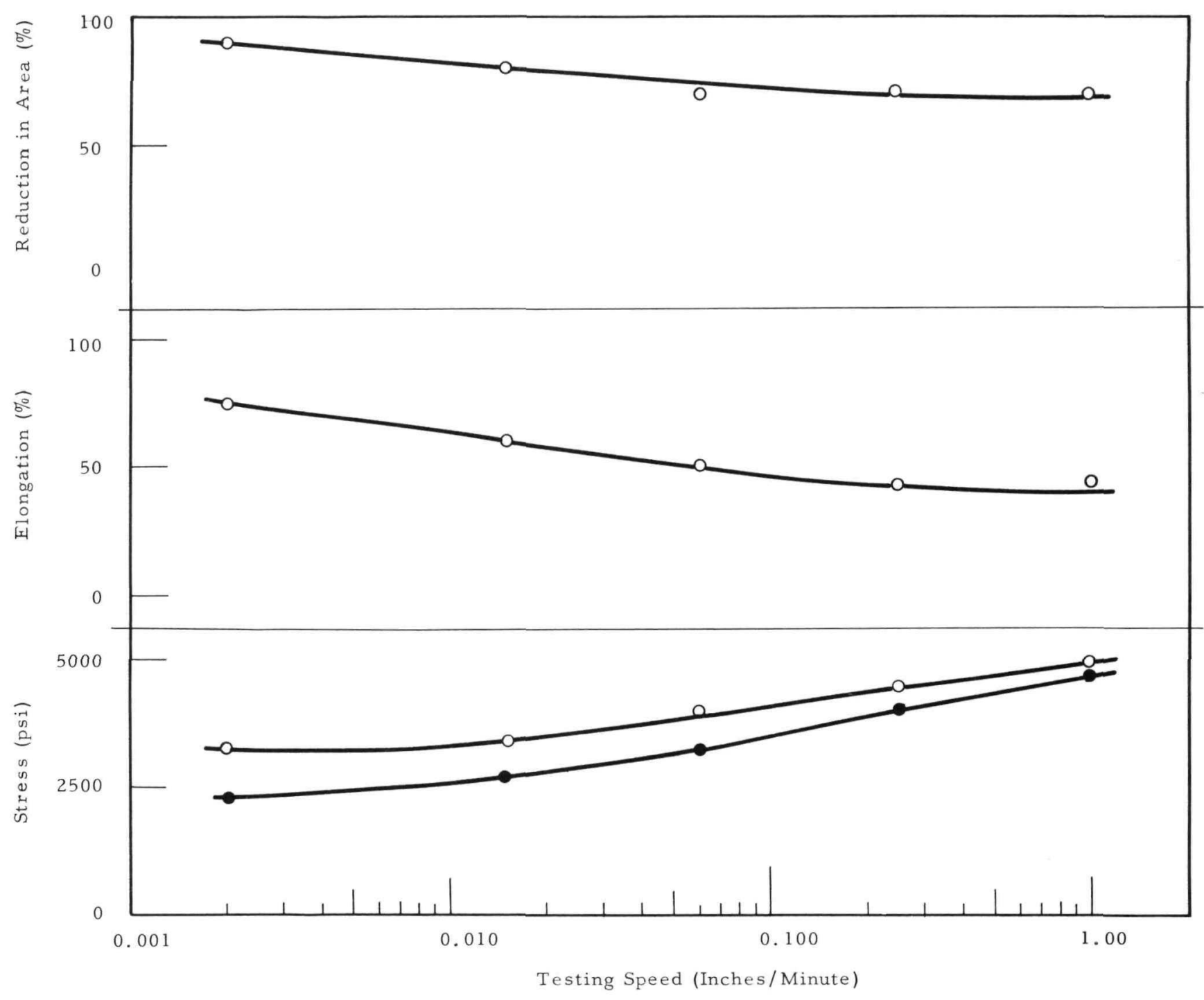

FIGURE 27

Effect of Testing Speed on Gamma Phase Properties at $265 \mathrm{C}$ 


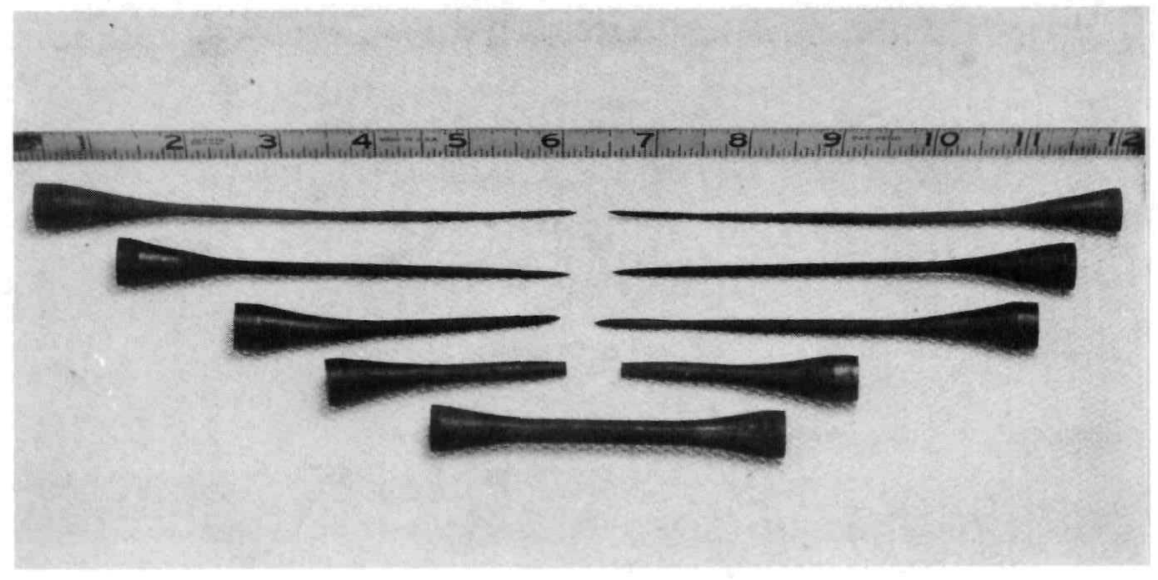

0.015 In. / Min.

0.060

0.250

1.0

As Machined

\section{FIGURE 28}

Beta Phase $-160^{\circ} \mathrm{C}$

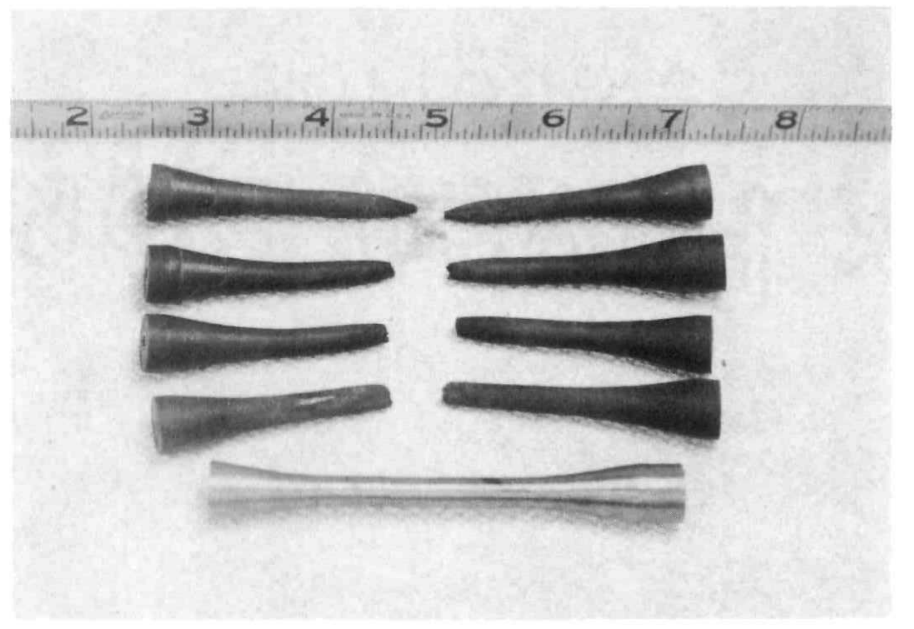

$0.002 \mathrm{In} / \mathrm{Min}$.

0.060

0.250

1.0

As Machined

\section{FIGURE 29 \\ Gamma Phase $-265^{\circ} \mathrm{C}$}

Type of Deformation and Fracture at Indicated Temperatures and Test Speeds . 


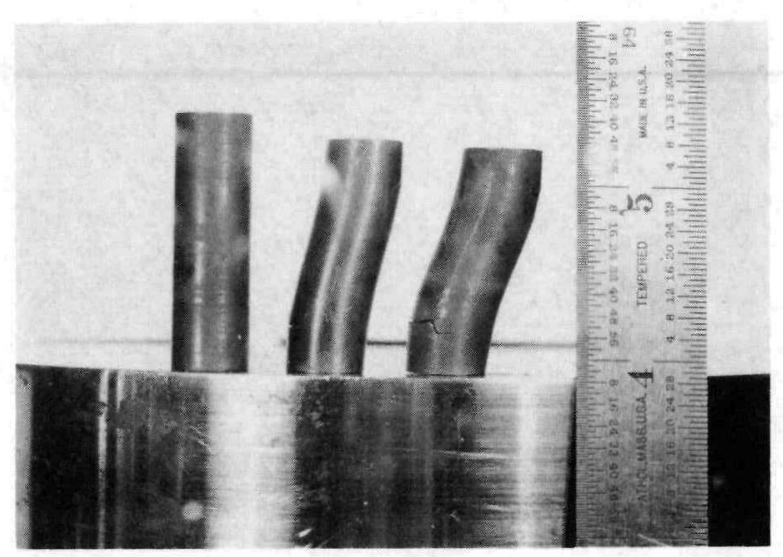

FIGURE 30

Compression Specimens with Height to Diameter Ratios of 3.3, Before and After Testing. Note Buckling and Peripheral Cracks which Occurred at a Stress of 110,000 psi.

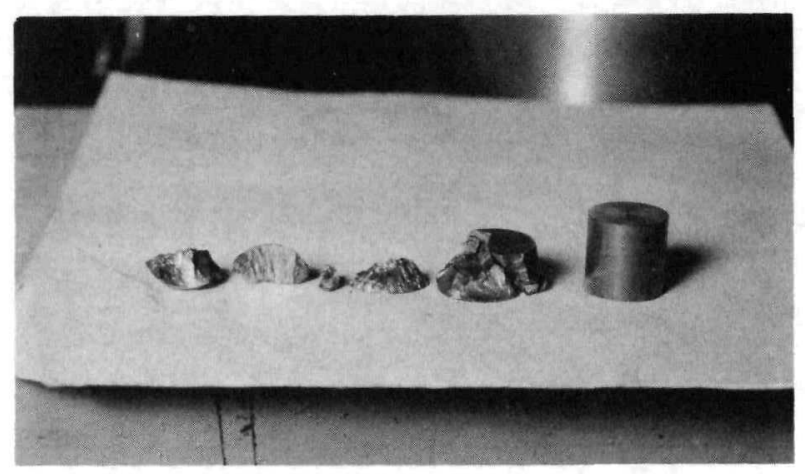

FIGURE 31

Fragmentation Accompanying Failure of 1.0 and $1.25 \mathrm{~h} / \mathrm{d}$ Ratio Specimens.

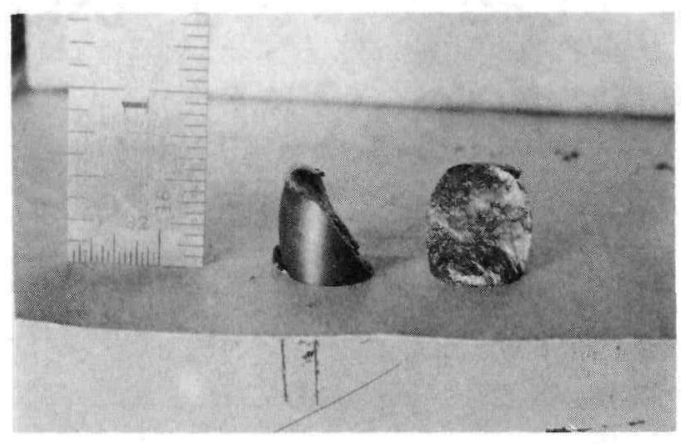

FIGURE $32 \mathrm{a}$

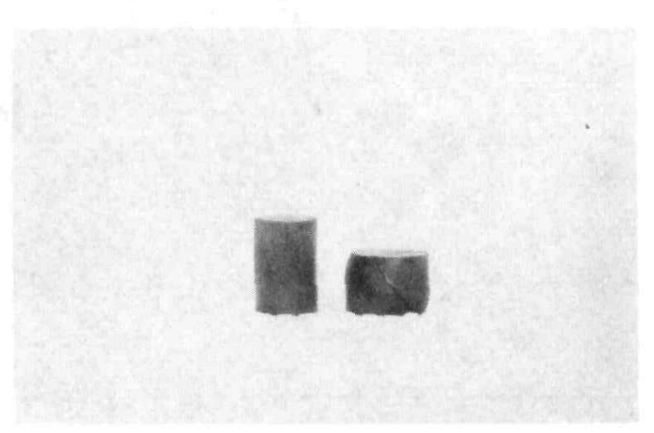

FIGURE $32 b$

Illustration of 450 Shear Failure and Barreling Produced in $1.5 \mathrm{~h} / \mathrm{d}$ Ratio Specimens at Test Temperatures of $30^{\circ} \mathrm{C}$ (Left) and $110^{\circ} \mathrm{C}$ (Right). 


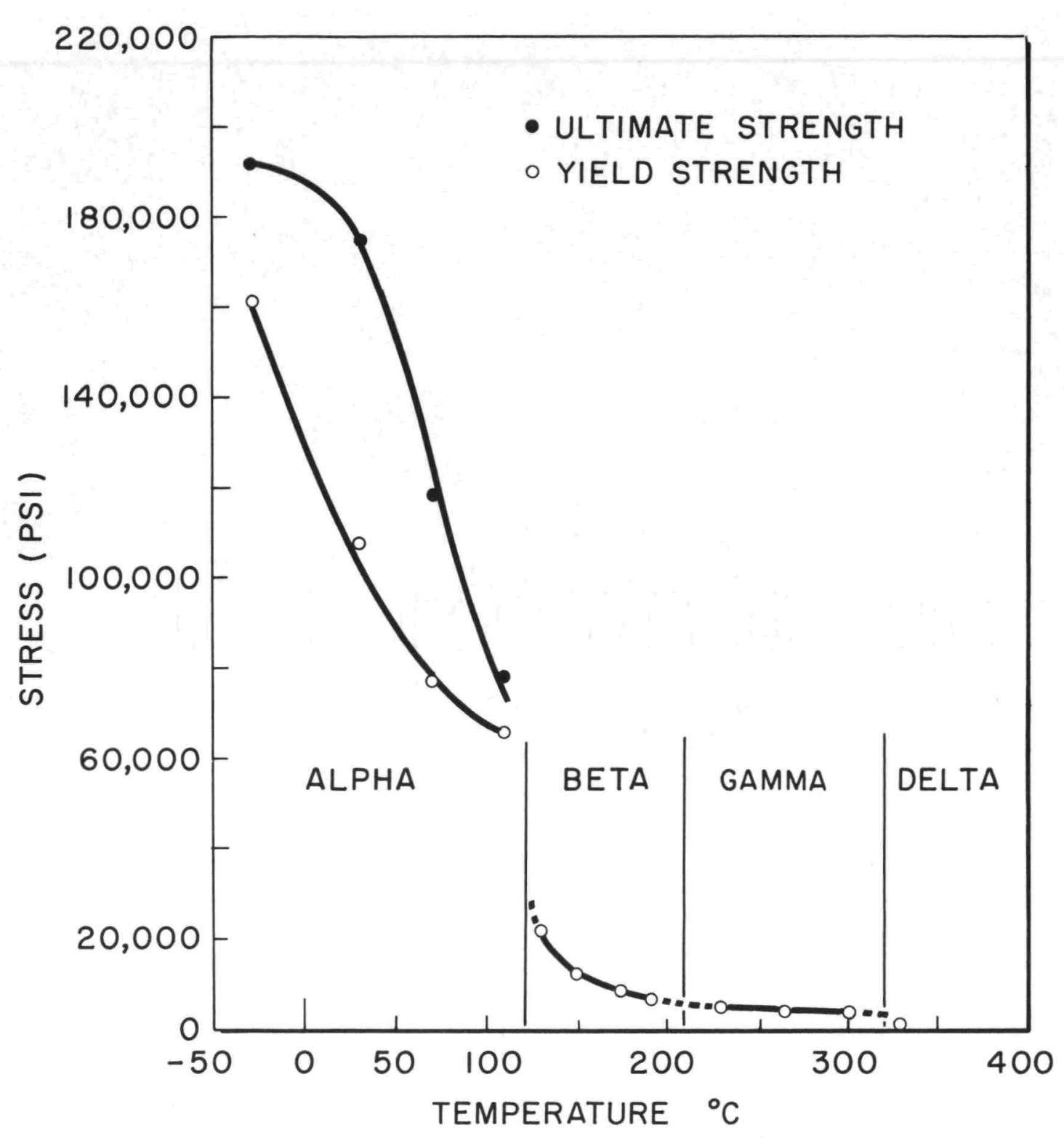

FIGURE 33

EFFECT OF TEMPERATURE ON AVERAGE COMPRESSIVE STRENGTH FOR HIGH DENSITY PLUTONIUM 


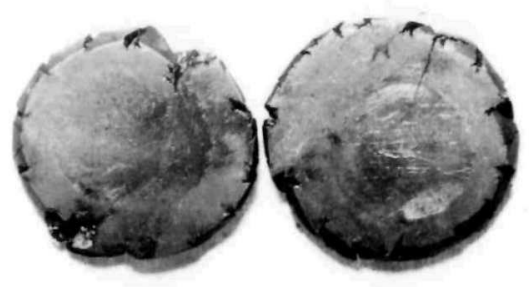

E-1

D -5

FIGURE 34

Specimens Loaded to $100,000 \mathrm{lbs}$. at $70^{\circ} \mathrm{C}, 1 \mathrm{X}$.

\section{Compression Direction $\longrightarrow$}

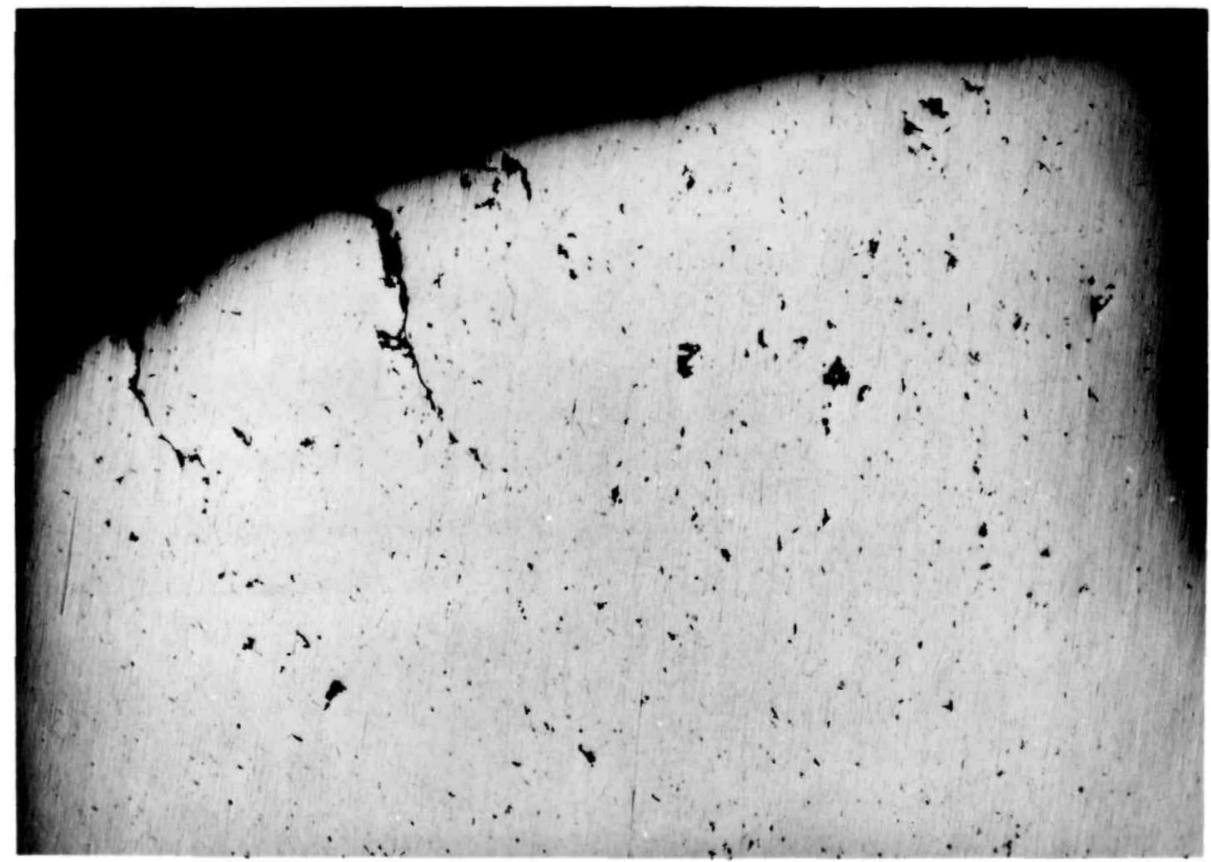

\section{FIGURE 35}

Peripheral Cracking in Specimen D-5 After Loading to 100,000 lbs., $50 X$. 


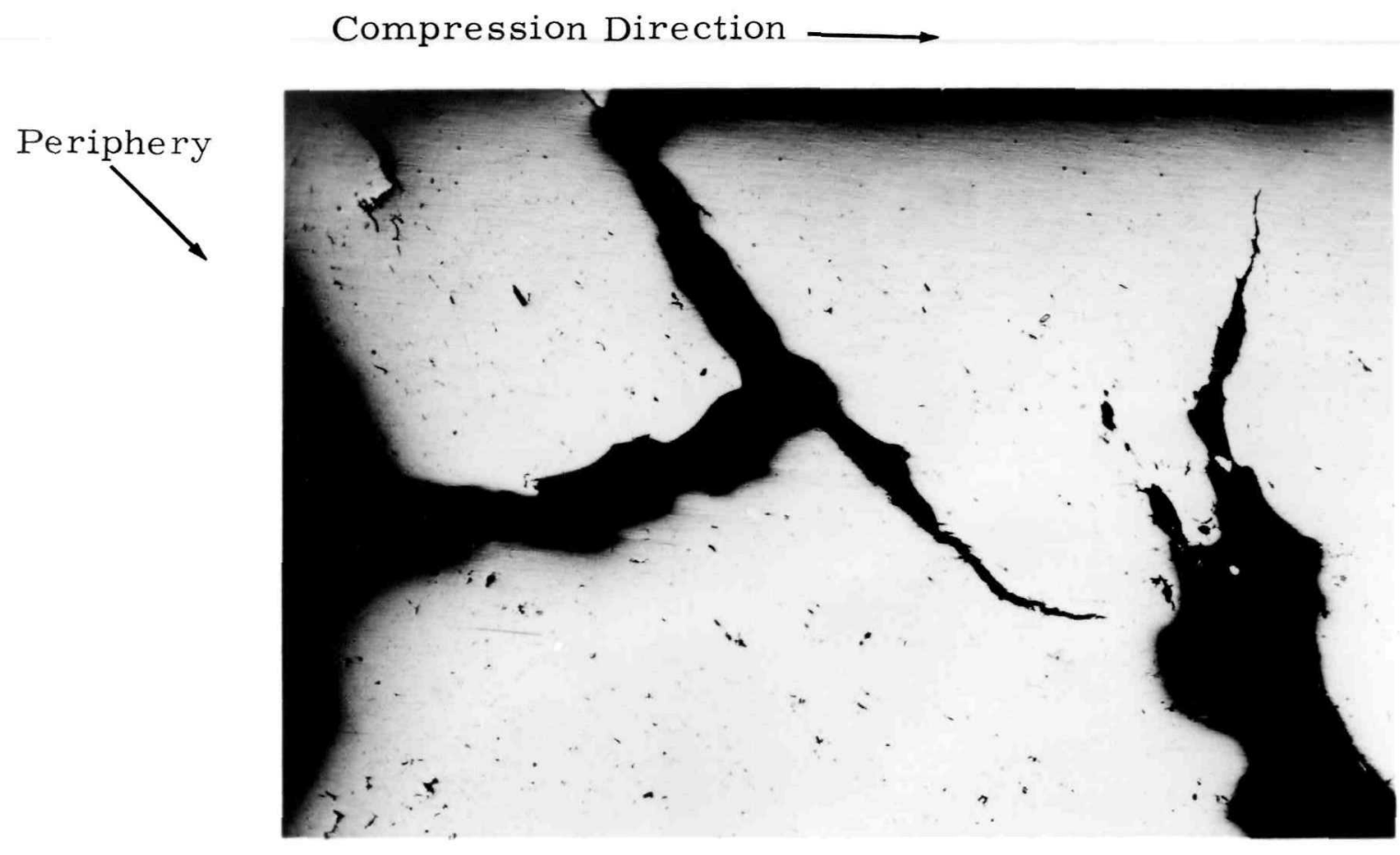

FIGURE 36

Cracking in Specimen D-5 After Loading to 100, $000 \mathrm{lbs}$, 50X.

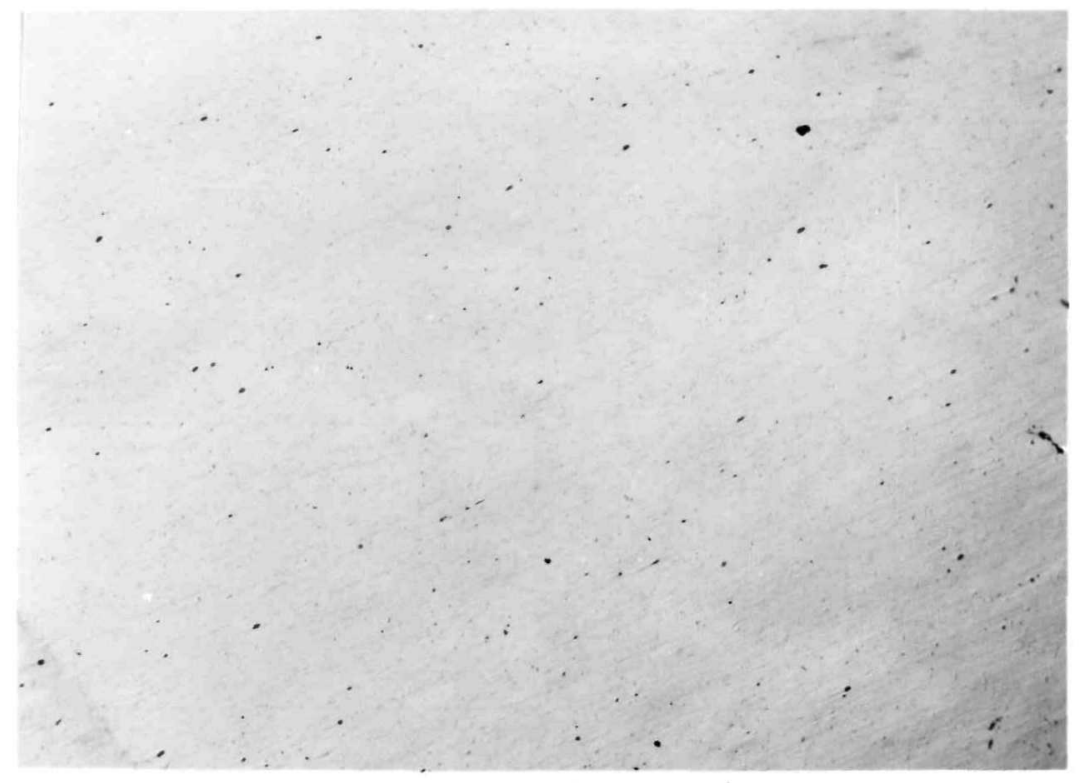

\section{FIGURE 37}

Typical of Crack Free Area Toward Center of Specimen D-5 After Loading to $100,000 \mathrm{lbs}$, 50X. 
Compression Direction

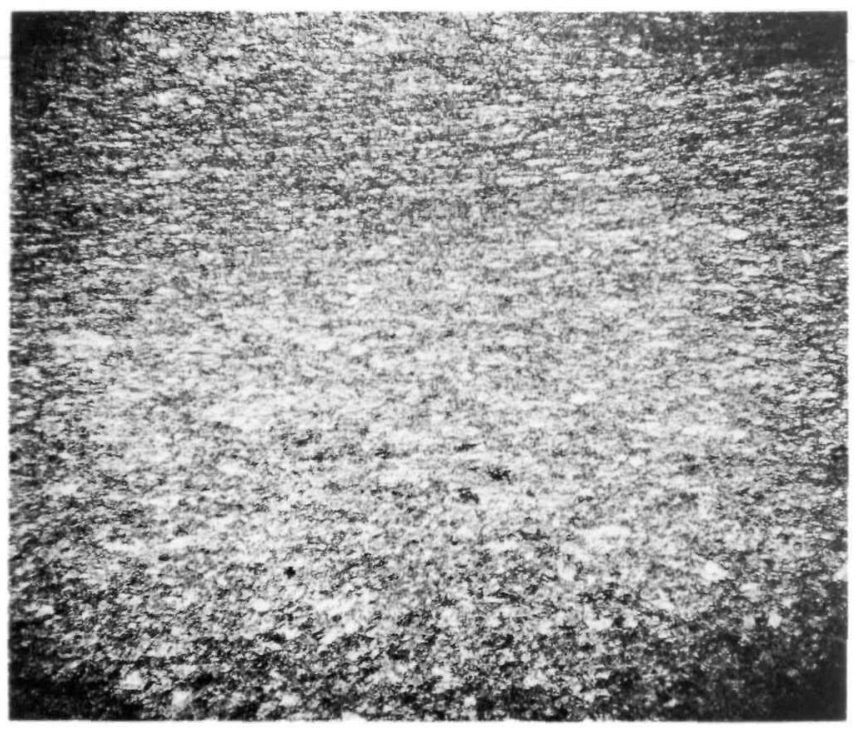

FIGURE 38

Variation in Grain Structure Across Thickness of Flattened Disc. Note Grain Elongation in Direction of Flow, $20 \mathrm{X}$.

Compression Direction

FIGURE 39

Same Area as Figure 38, 50X.

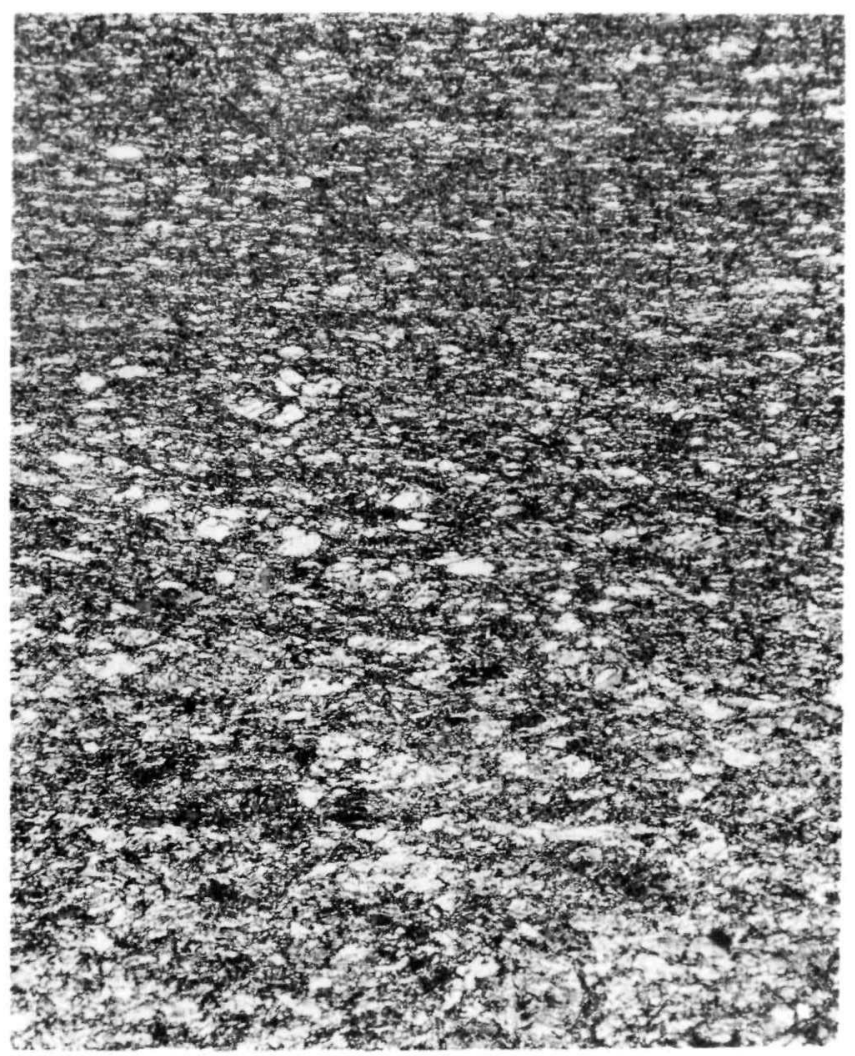




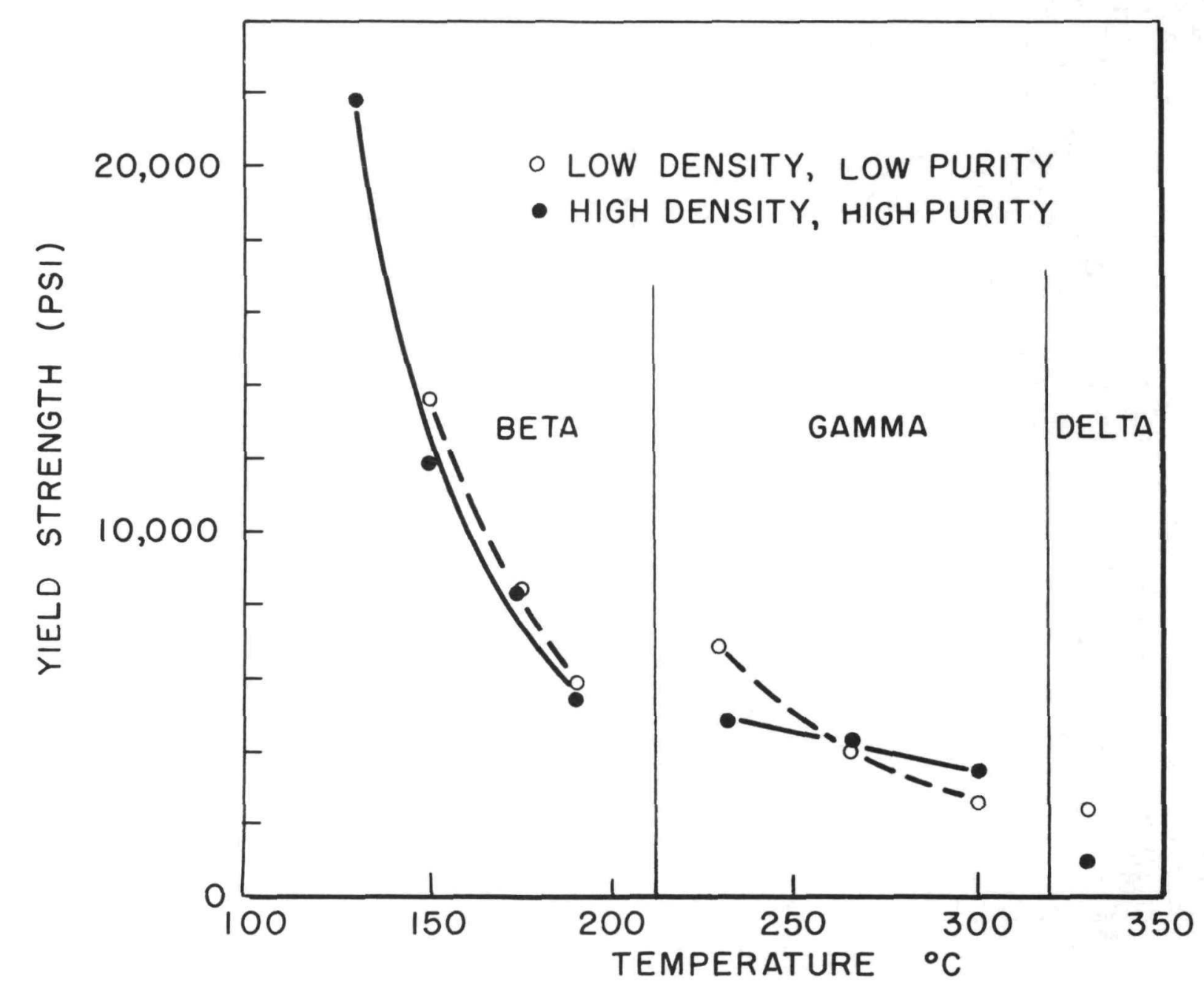

I

FIGURE 40

EFFECT OF METAL QUALITY ON YIELD STRENGTH IN THE BETA, GAMMA AND DELTA PHASES 


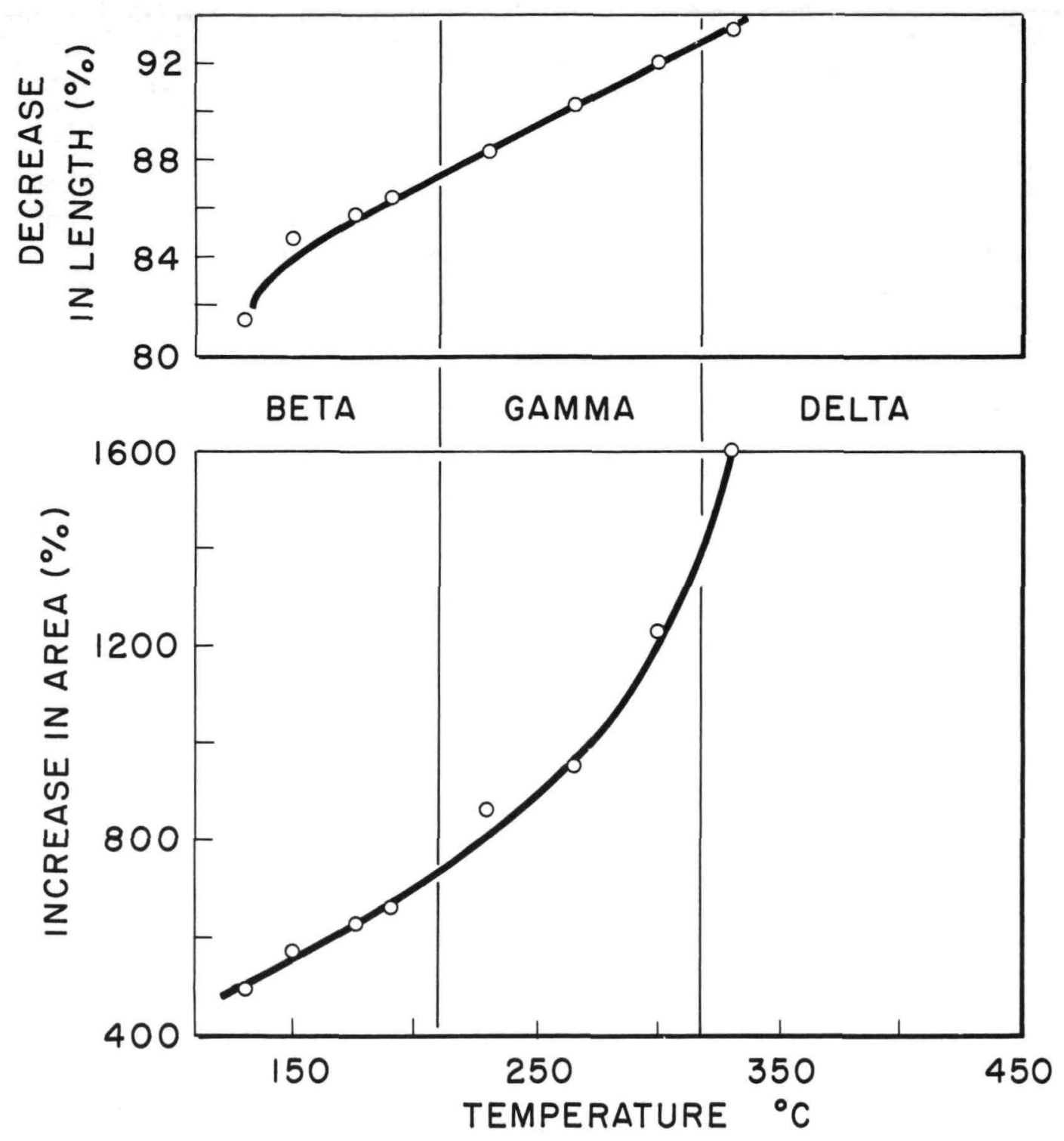

FIGURE 41

EFFECT OF TEMPERATURE ON FORMABILITY IN COMPRESSION

DETERMINED AFTER LOADING THE SPECIMEN TO 100,000 LBS. THE INITIAL SPECIMEN SIZE WAS 0.500 IN. DIA. X 0.750 IN. HEIGHT 


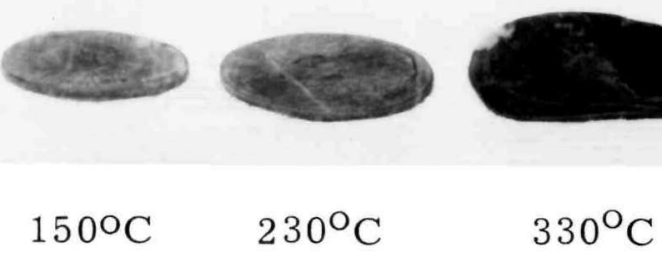

FIGURE 42

Relative Degree of Formability at 100,000 lbs. Load for the 150,230 and $330^{\circ} \mathrm{C}$ Test Temperature in the Beta, Gamma and Delta Phases, Respectively, $1 / 2 \mathrm{X}$.

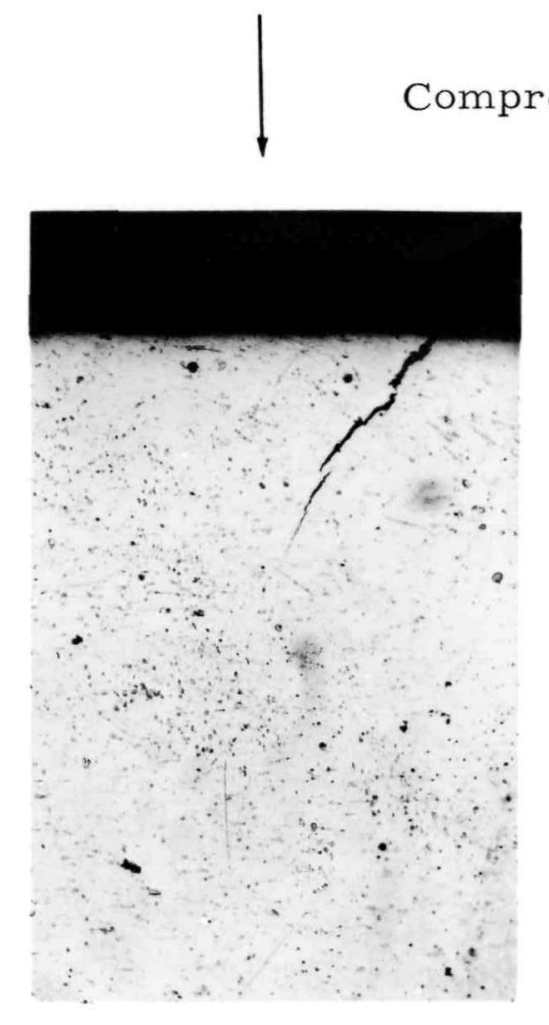

FIGURE 43

Crack Formed During Compression to $100,000 \mathrm{lbs}$. at $150^{\circ} \mathrm{C}$, $50 \mathrm{x}$.

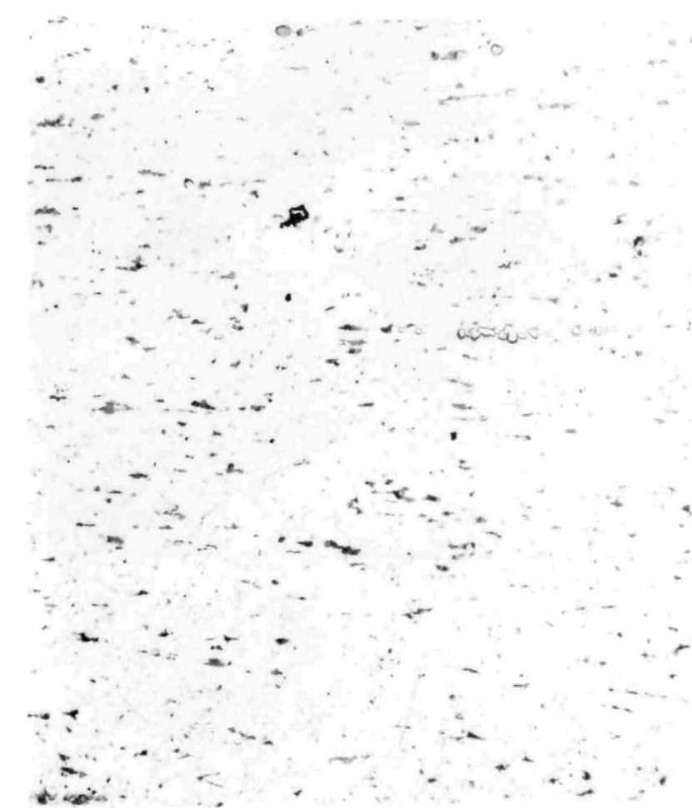

FIGURE 44

Elongation of Inclusions in Direction of Flow, During Compression to $100,000 \mathrm{lbs}$. at $150^{\circ} \mathrm{C}, 100 \mathrm{X}$. 


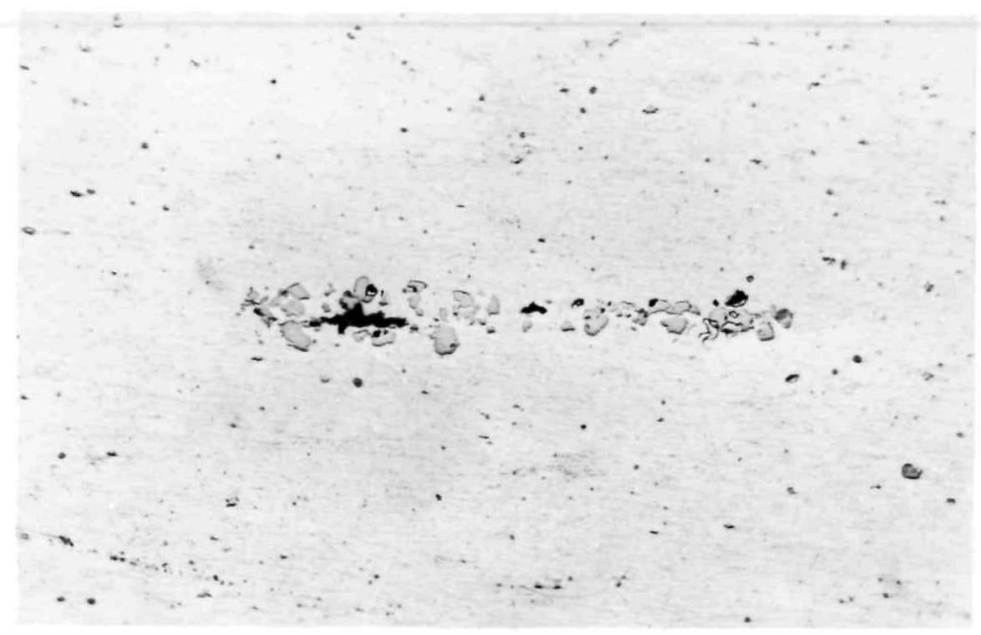

FIGURE 45

Elongation of Plutonium Nitride Cluster During Compression to 100, 000 lbs. at $150^{\circ} \mathrm{C}, 250 \mathrm{X}$.

$\downarrow$ Compression Direction $\downarrow$

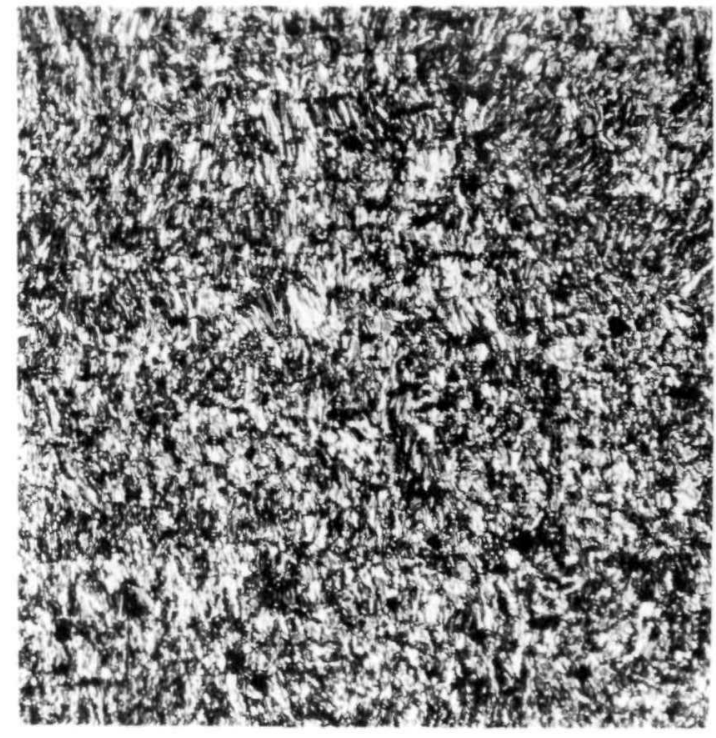

FIGURE 46

Non-uniform Grain Structure Present in Plutonium Compressed to $100,000 \mathrm{lbs}$. at $150^{\circ} \mathrm{C}$. Grain Size $-0.012 \mathrm{~mm}, 100 \mathrm{X}$.

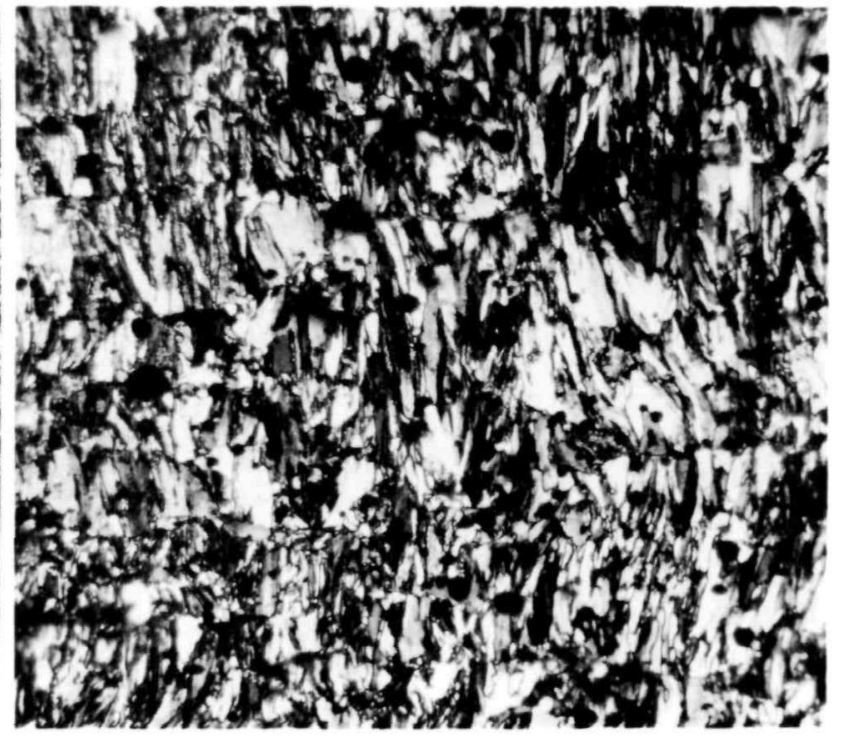

FIGURE 47

Columnar Grains Aligned in Compression Direction, for Specımen Compressed to $100,000 \mathrm{lbs}$. at $150^{\circ} \mathrm{C}, 250 \mathrm{X}$. 
Compression Direction $\downarrow$

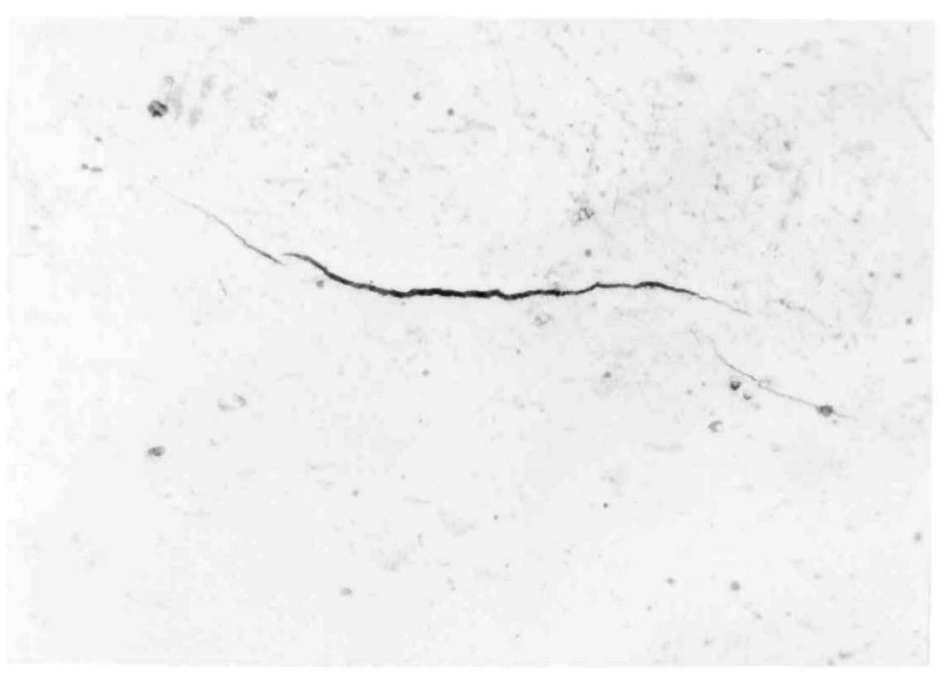

FIGURE 48

Interior Crack Developed During Compression to $100,000 \mathrm{lbs}$. at $230^{\circ} \mathrm{C}$, $250 \mathrm{x}$.

\section{Compression Direction}

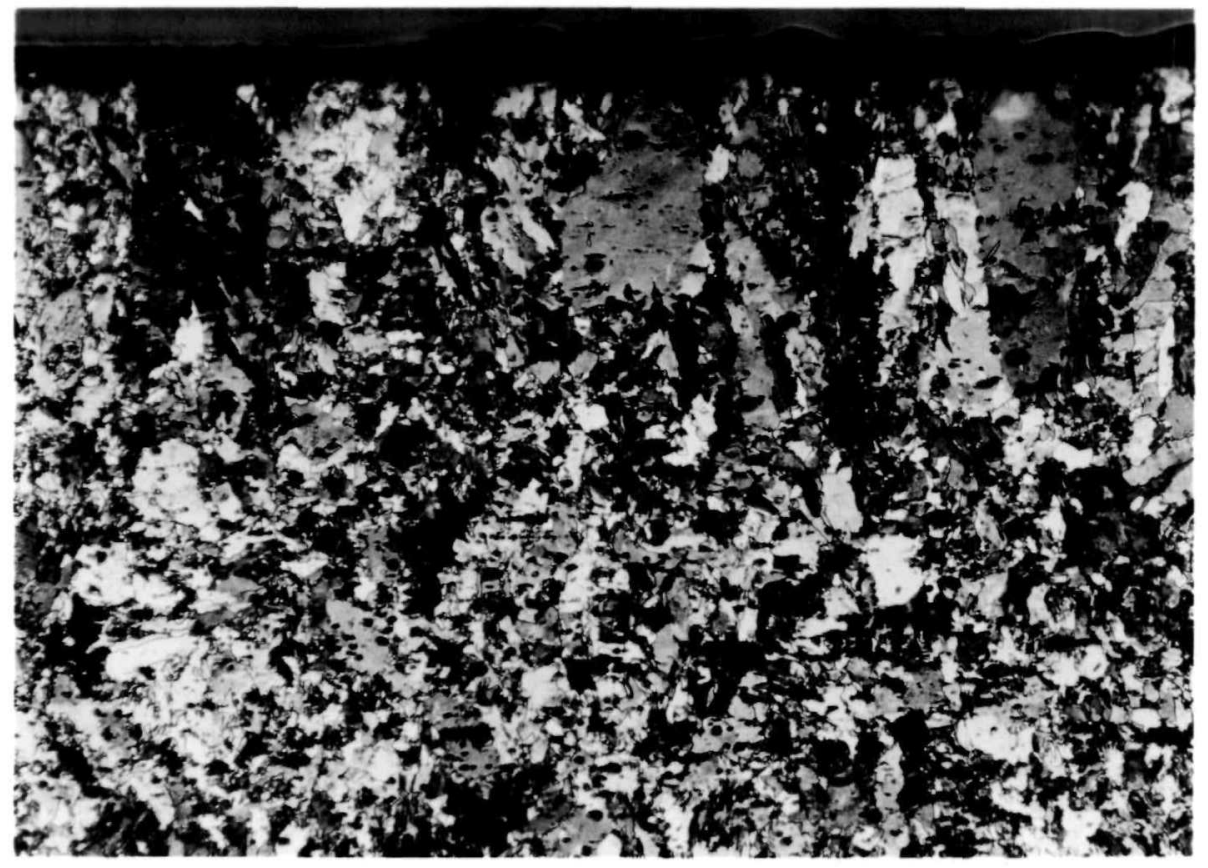

FIGURE 49

Columnar Grains at Compression Surface of Gamma Compressed Specimen, $300^{\circ} \mathrm{C}$. Grain Size of Non-columnar Region - $0.047 \mathrm{~mm}, 100 \mathrm{X}$. 
Compression Direction $\downarrow$

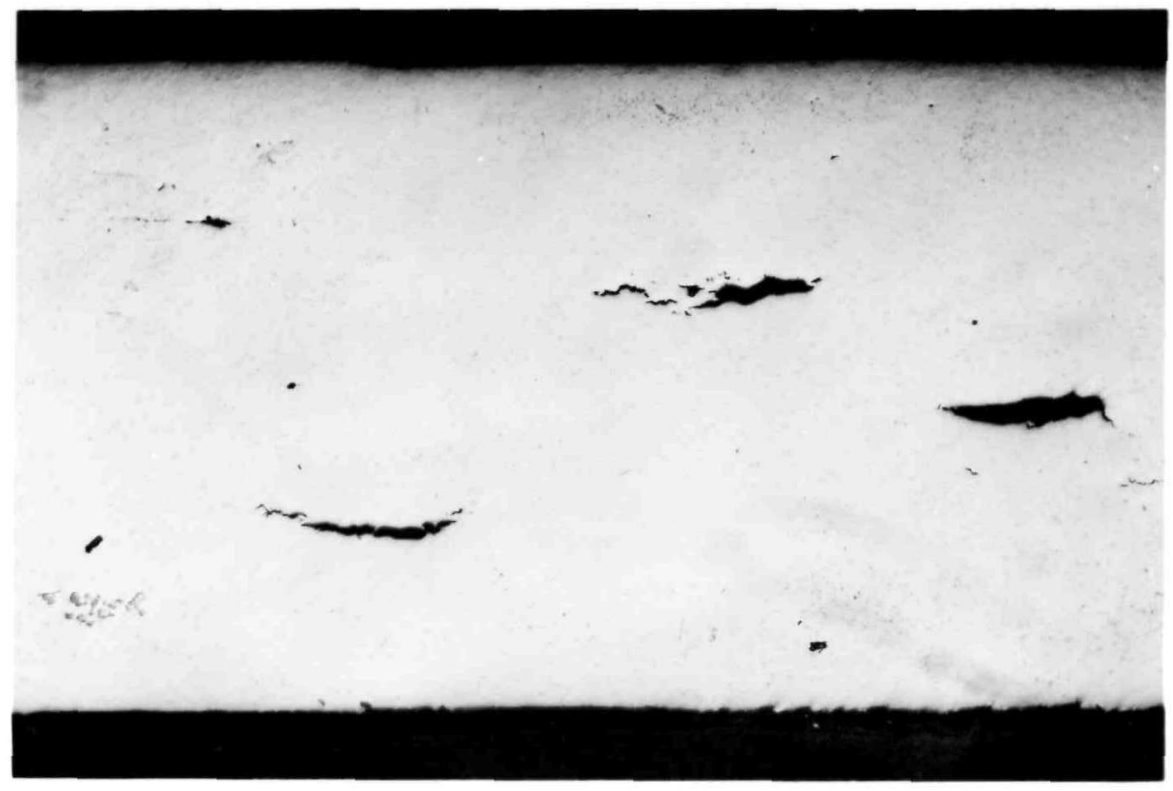

FIGURE 50

Cracks Resulting from Delta Phase Compression to 100,000 lbs at $330^{\circ} \mathrm{C}$, $50 \mathrm{X}$.

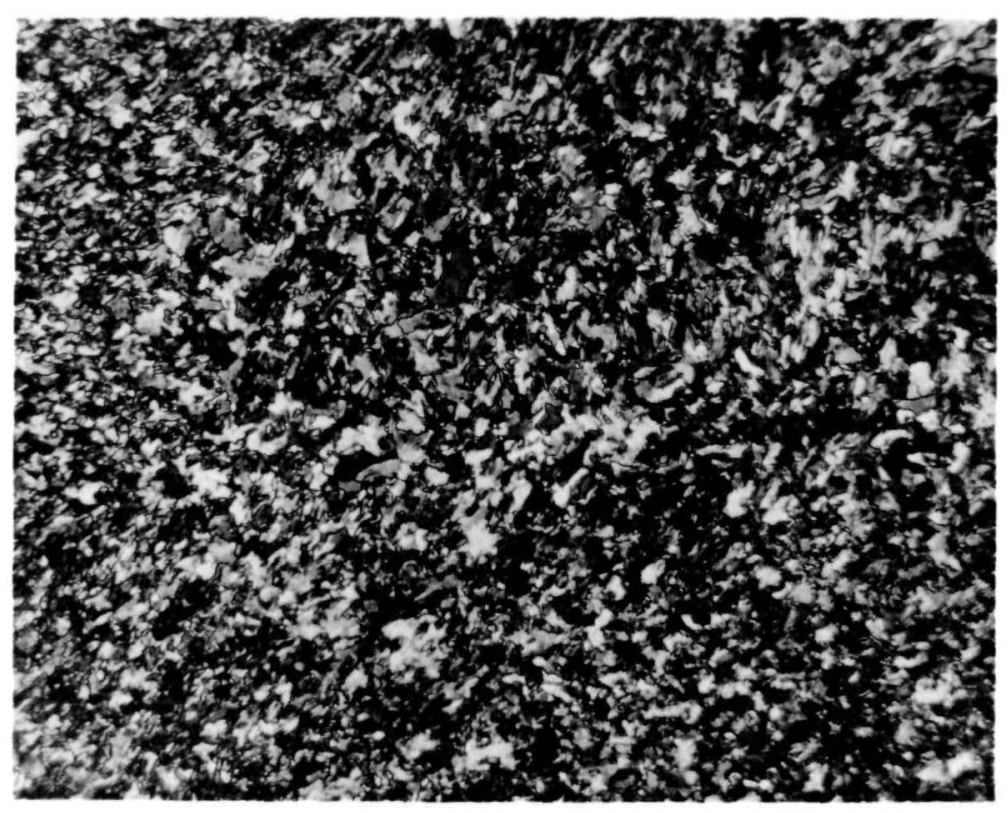

FIGURE 51

Typical Grain Structure of Delta Compressed Plutonium, $330^{\circ} \mathrm{C}$. Grain Size, $0.0089 \mathrm{~mm}, 250 \mathrm{X}$ 


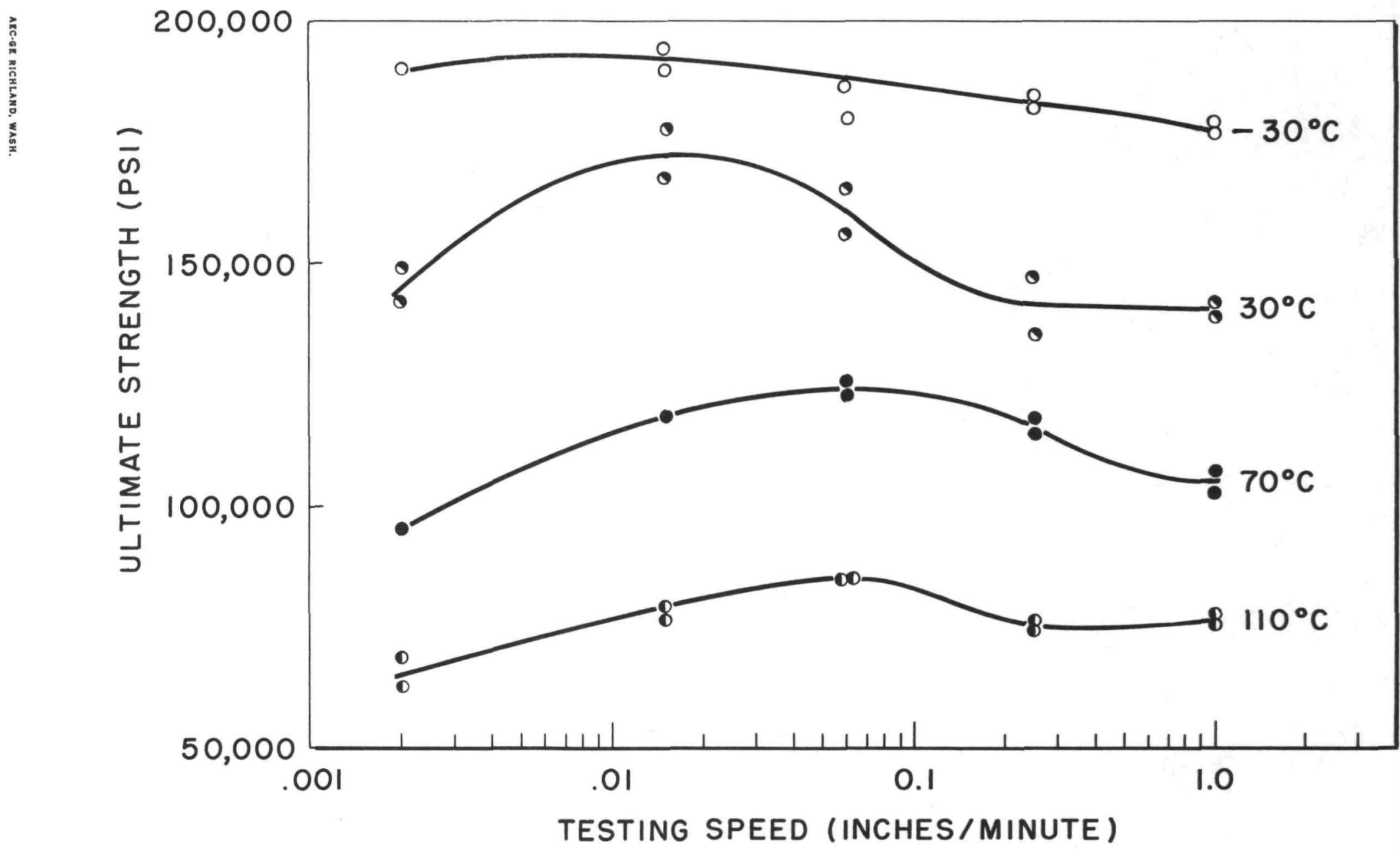

FIGURE 52

EFFECT OF TESTING SPEED ON ULTIMATE STRENGTH IN COMPRESSION 


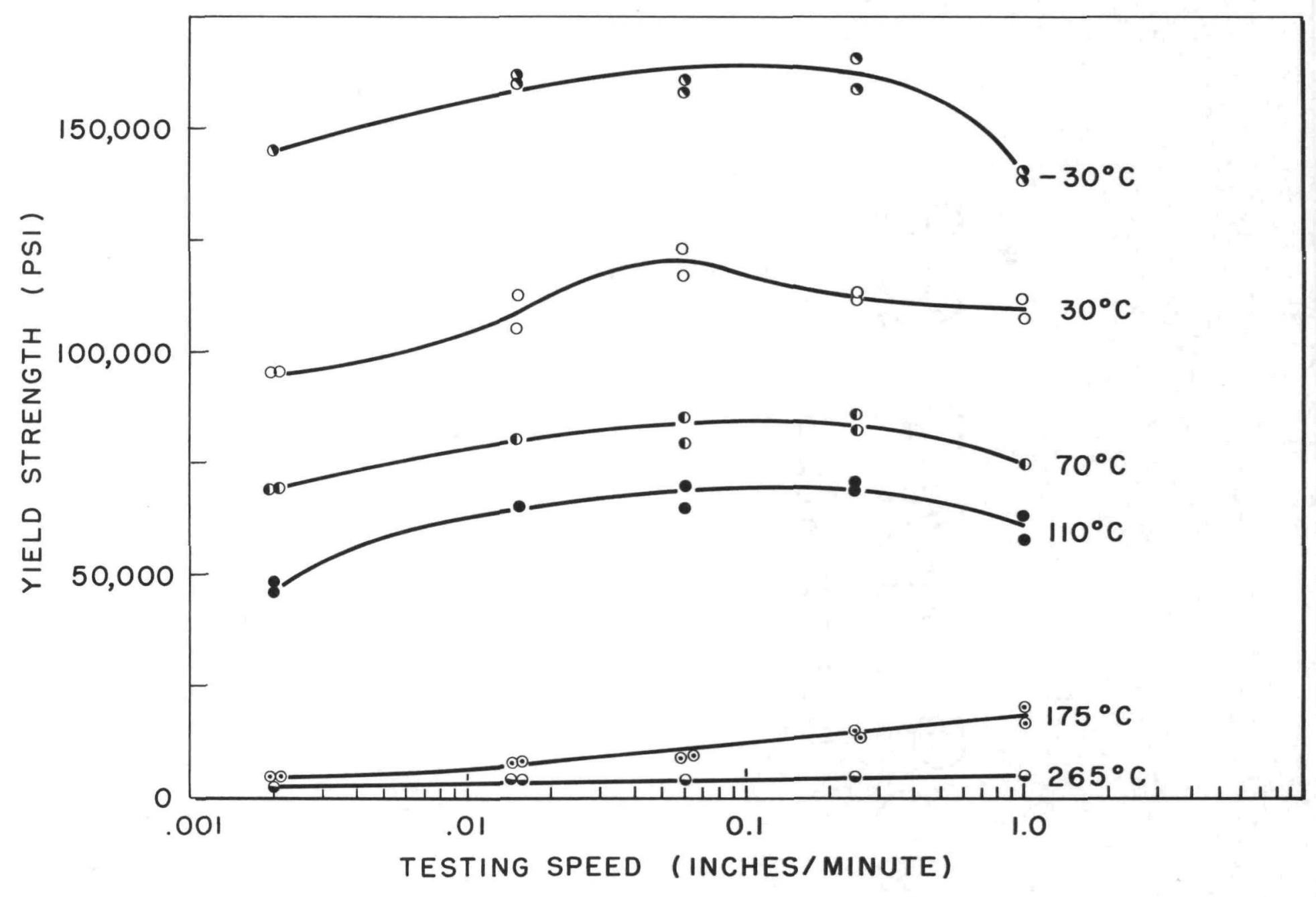

FIGURE 53

EFFECT OF TESTING SPEED ON YIELD STRENGTH IN COMPRESSION 


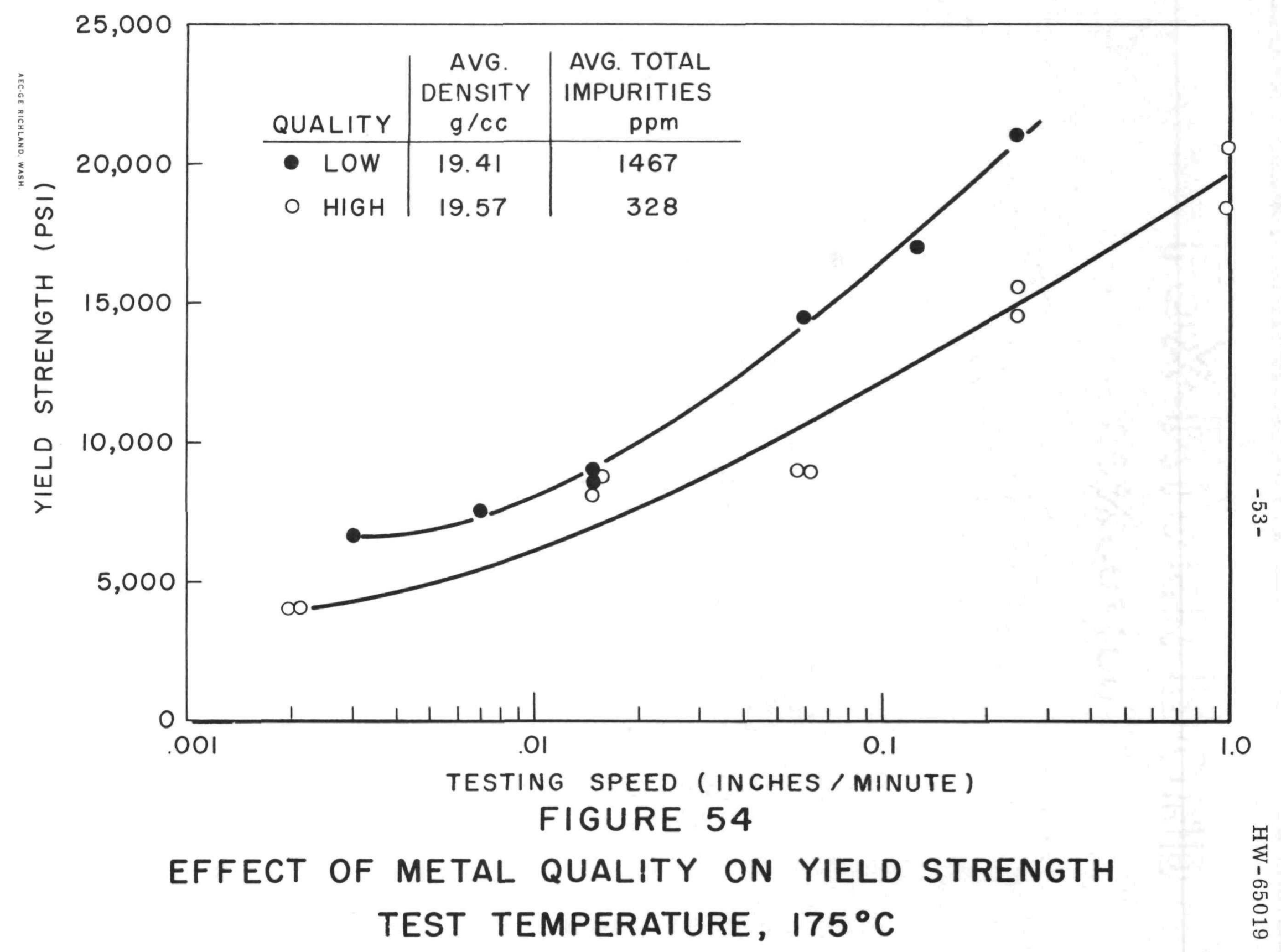




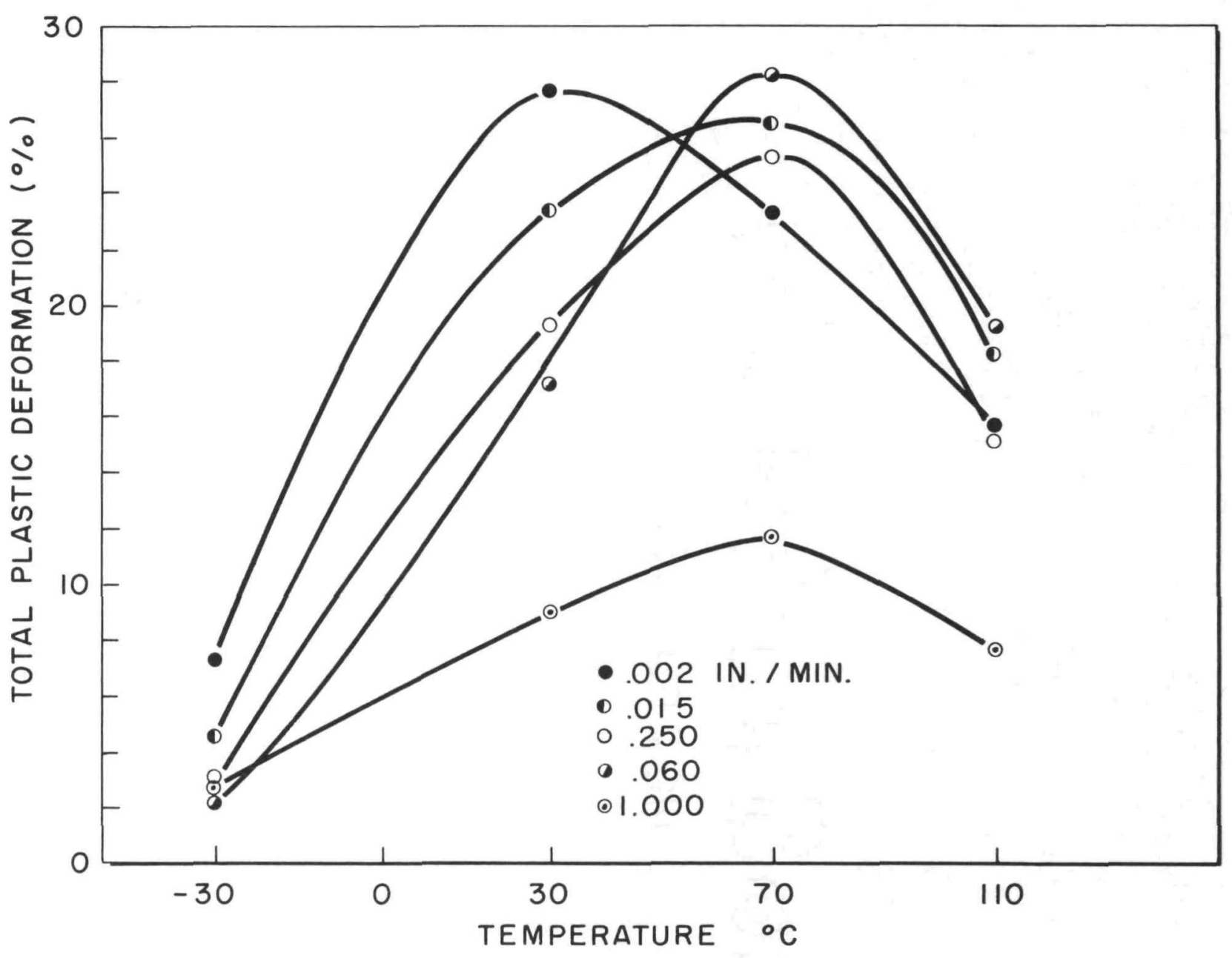

FIGURE 55

EFFECT OF TEMPERATURE ON TOTAL PLASTIC DEFORMATION PRIOR TO FRACTURE, WITH TESTING SPEED AS A PARAMETER 


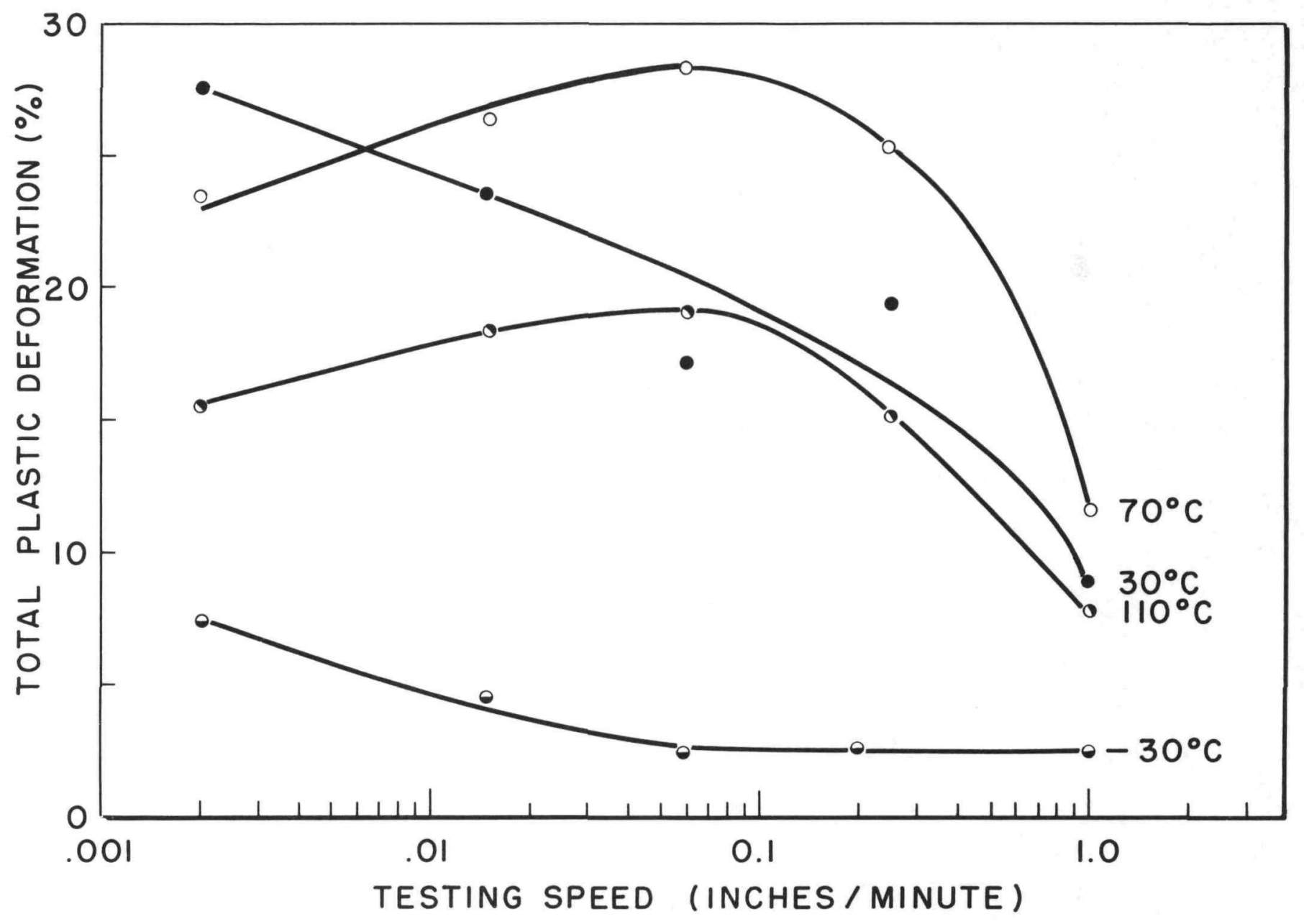

FIGURE 56

EFFECT OF TESTING SPEED ON TOTAL PLASTIC DEFORMATION PRIOR TO FRACTURE 


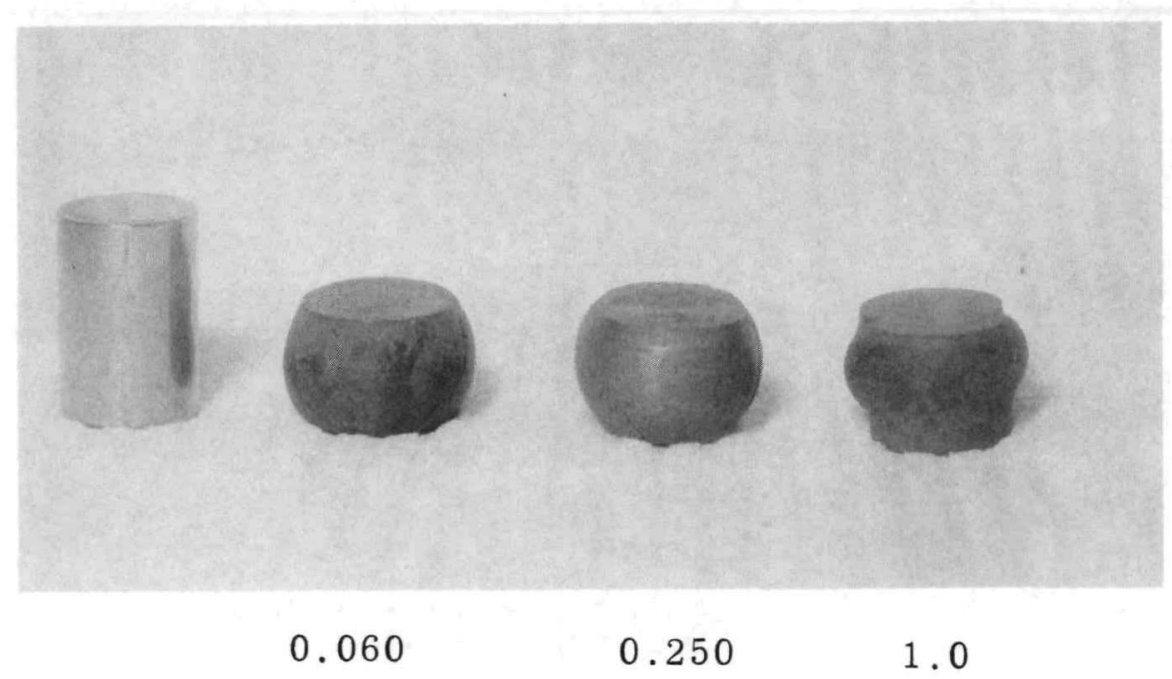

FIGURE 57

Effect of Testing Speed on Deformation Characteristics at $110^{\circ} \mathrm{C}$ for the $0.060,0.250$ and $1.0 \mathrm{Inch} /$ Minute Testing Speeds. Plane of Shear Fracture is $45^{\circ}$ Back from the Plane of the Photograph. $1 \mathrm{X}$.

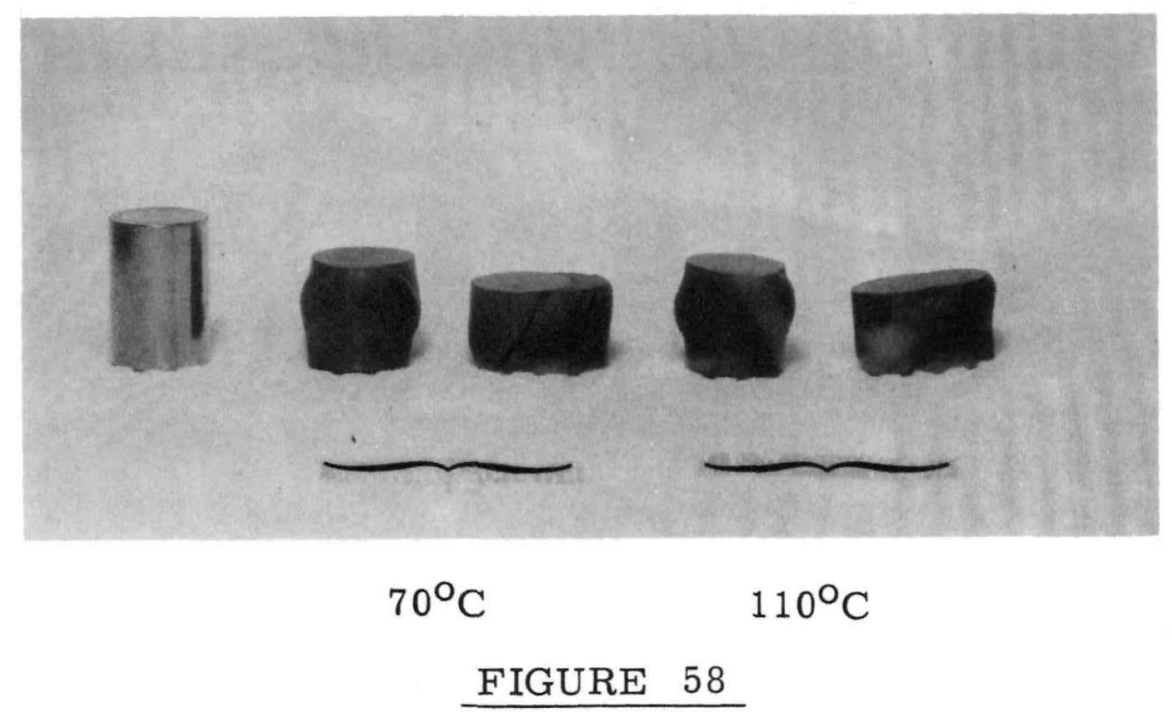

Specimens Tested at 70 and $110^{\circ} \mathrm{C}$ at a Testing Speed of 1.0 Inches/Minute. Bulging is Apparent in the Specimens at the Left for Each Testing Temperature, While the Shear Type Failure is Illustrated in the Right Hand Specimens which are at a $90^{\circ}$ Angle to those on the Left. $3 / 4 \mathrm{X}$. 


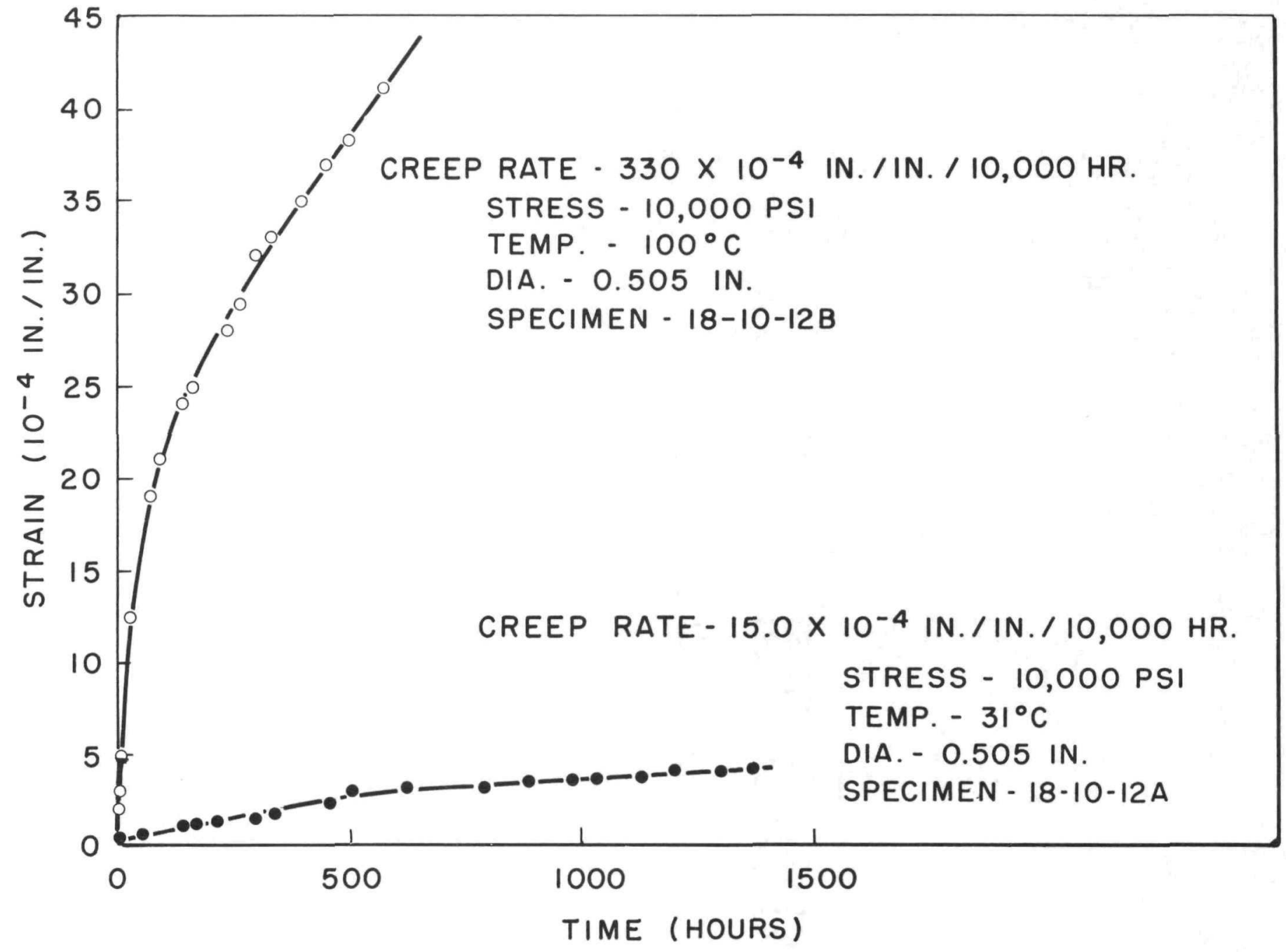

FIGURE 59

ALPHA PLUTONIUM CREEP CURVES 


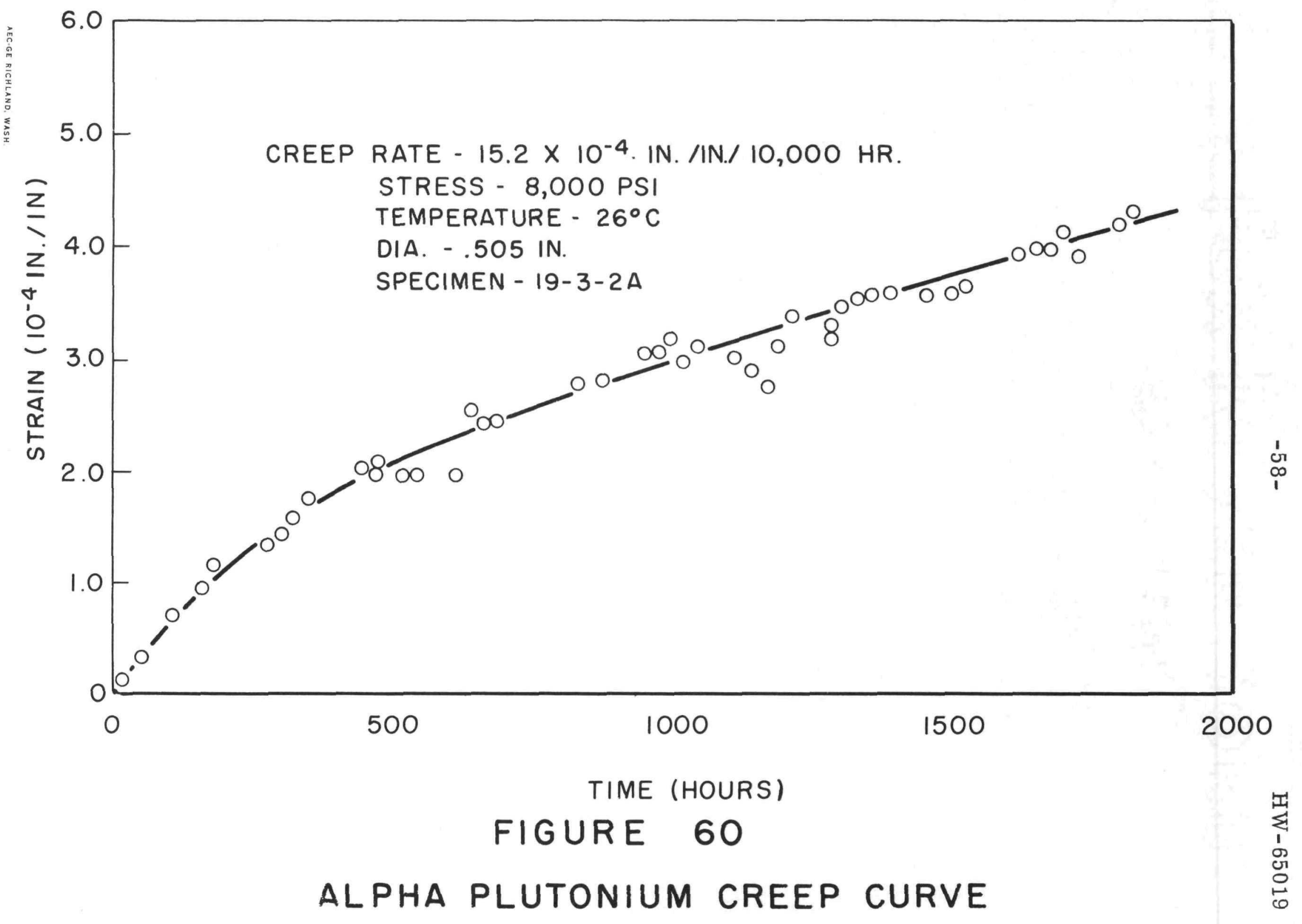




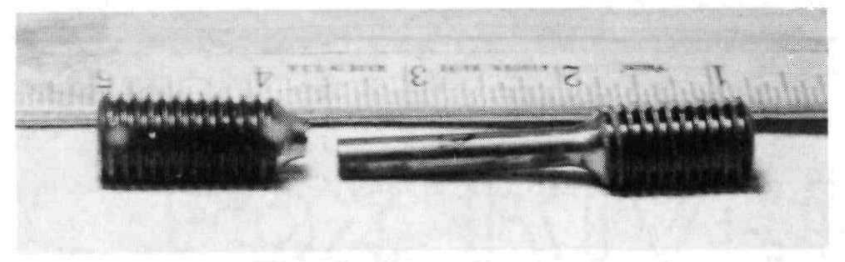

\section{FIGURE 61}

Typical Brittle Fracture Occurring in Tension Impact Specimens.

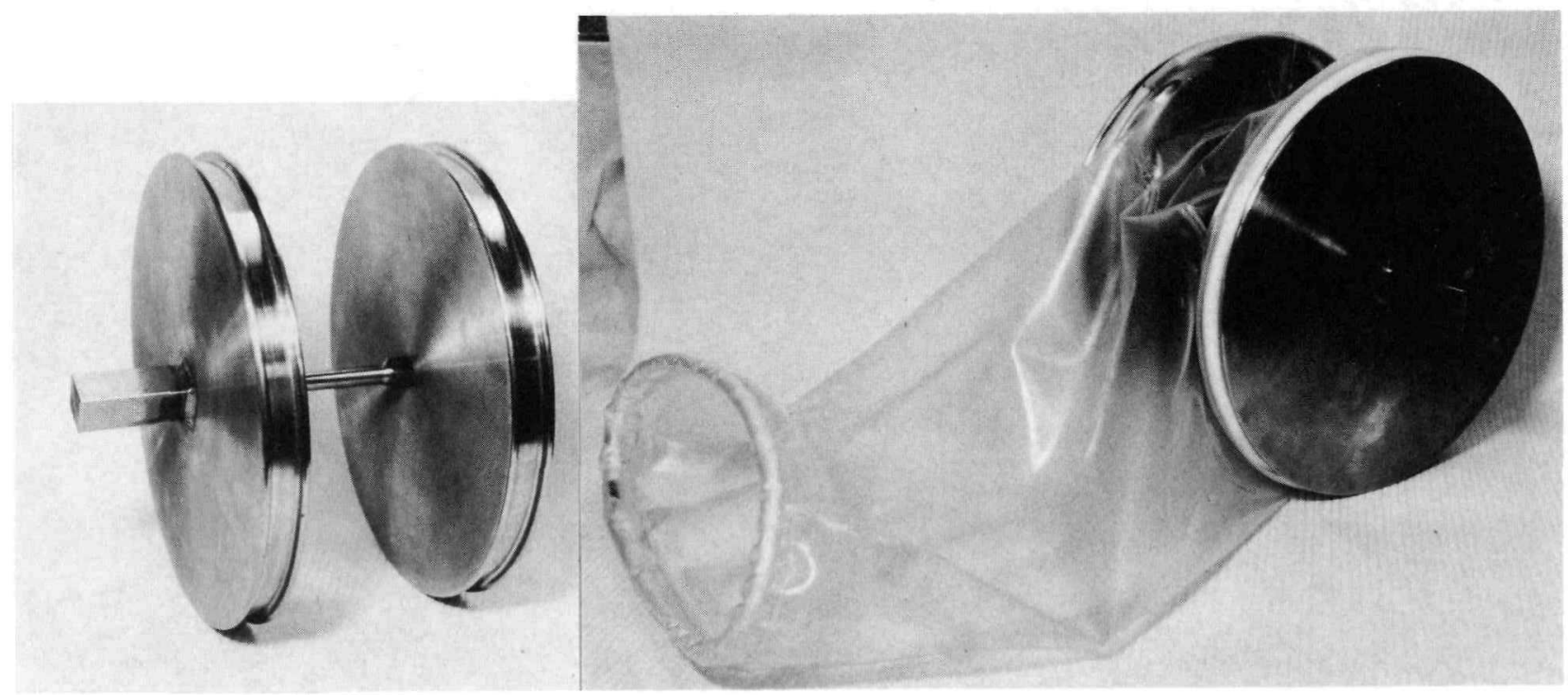

\section{FIGURE 62}

Fixture for Torsion Testing, at Left the Specimen Position is Illustrated, at Right the Fixture is Encased in the Plastic Container, 1/4X.

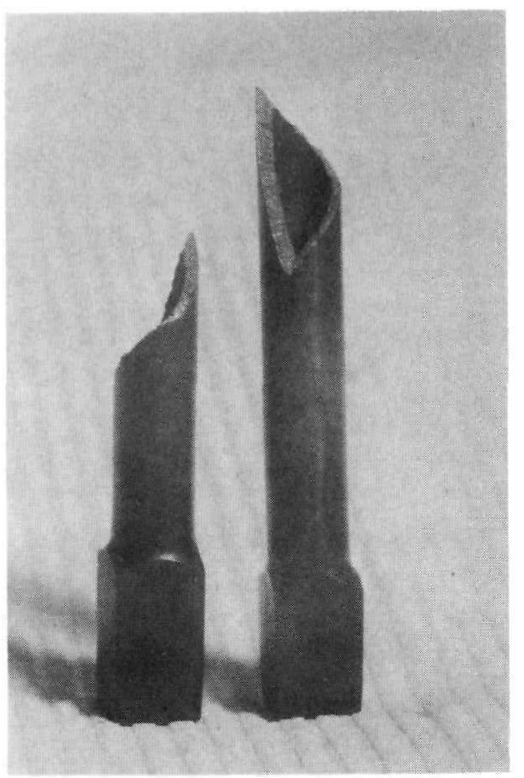

FIGURE 63

Brittle Fracture Occurring in Torsion Specimen, $1 \mathrm{X}$. 


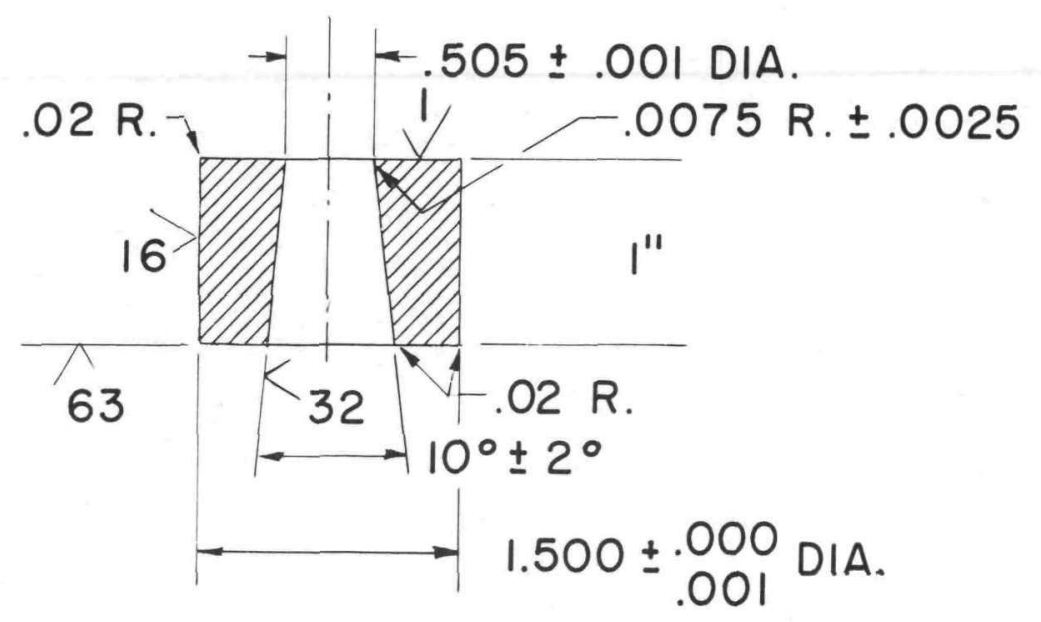

SHEAR EXTRUSION DIE

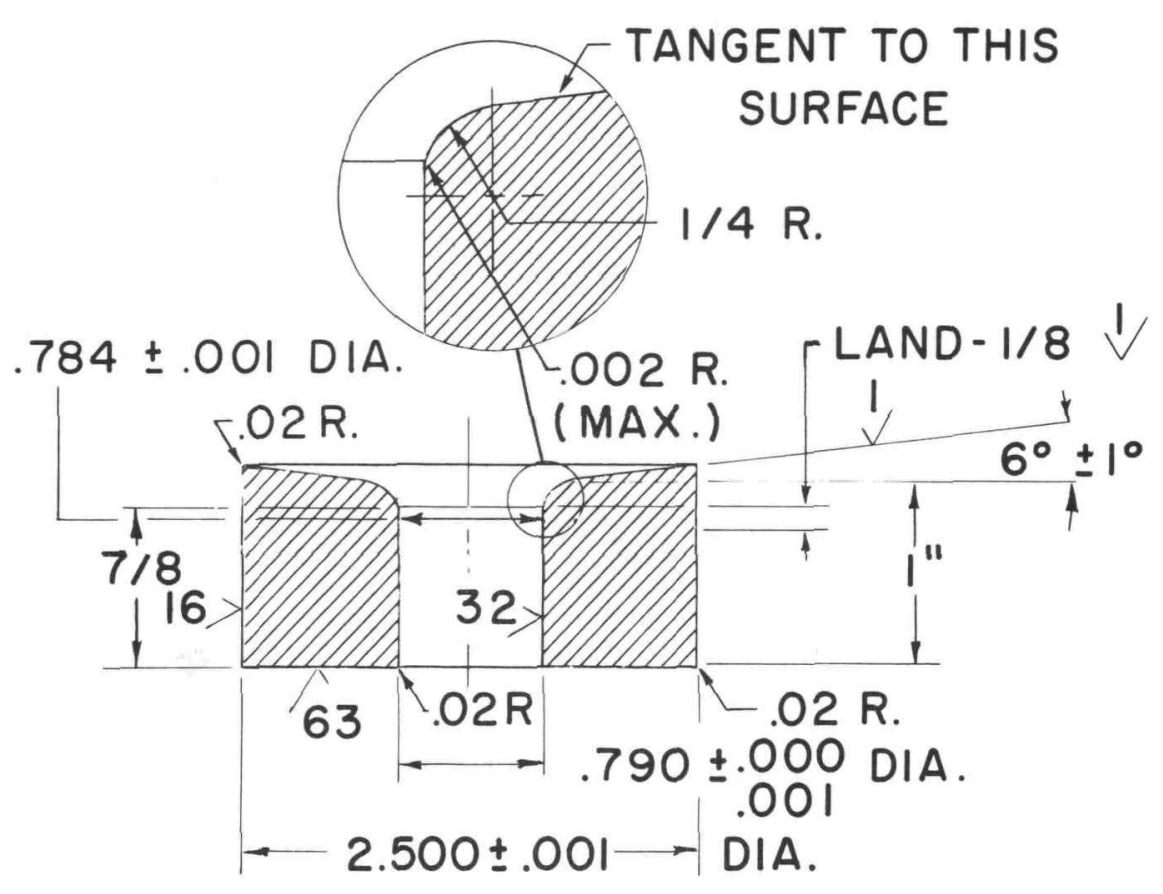

STREAMLINE EXTRUSION DIE

FIGURE 64

\section{DIES USED IN PLUTONIUM EXTRUSION}




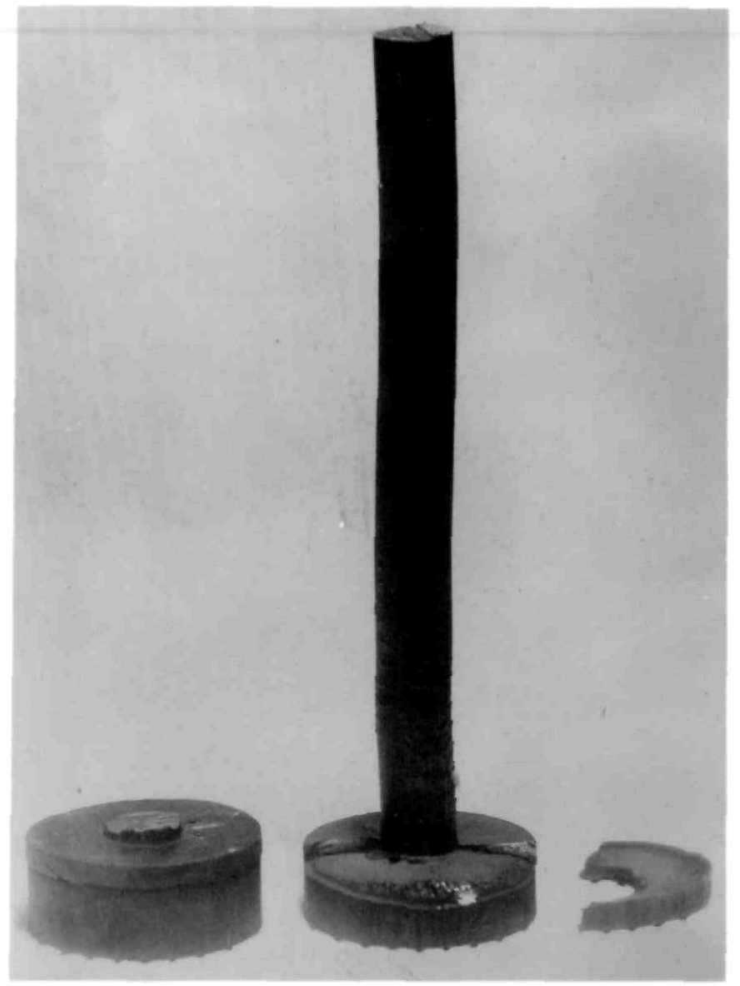

\section{FIGURE 65}

Gamma Extruded Rod 18-12-3C. Note that Bonding did not Occur Between the Dead Metal-Flowing Metal Interface, $1 / 2 \mathrm{X}$.
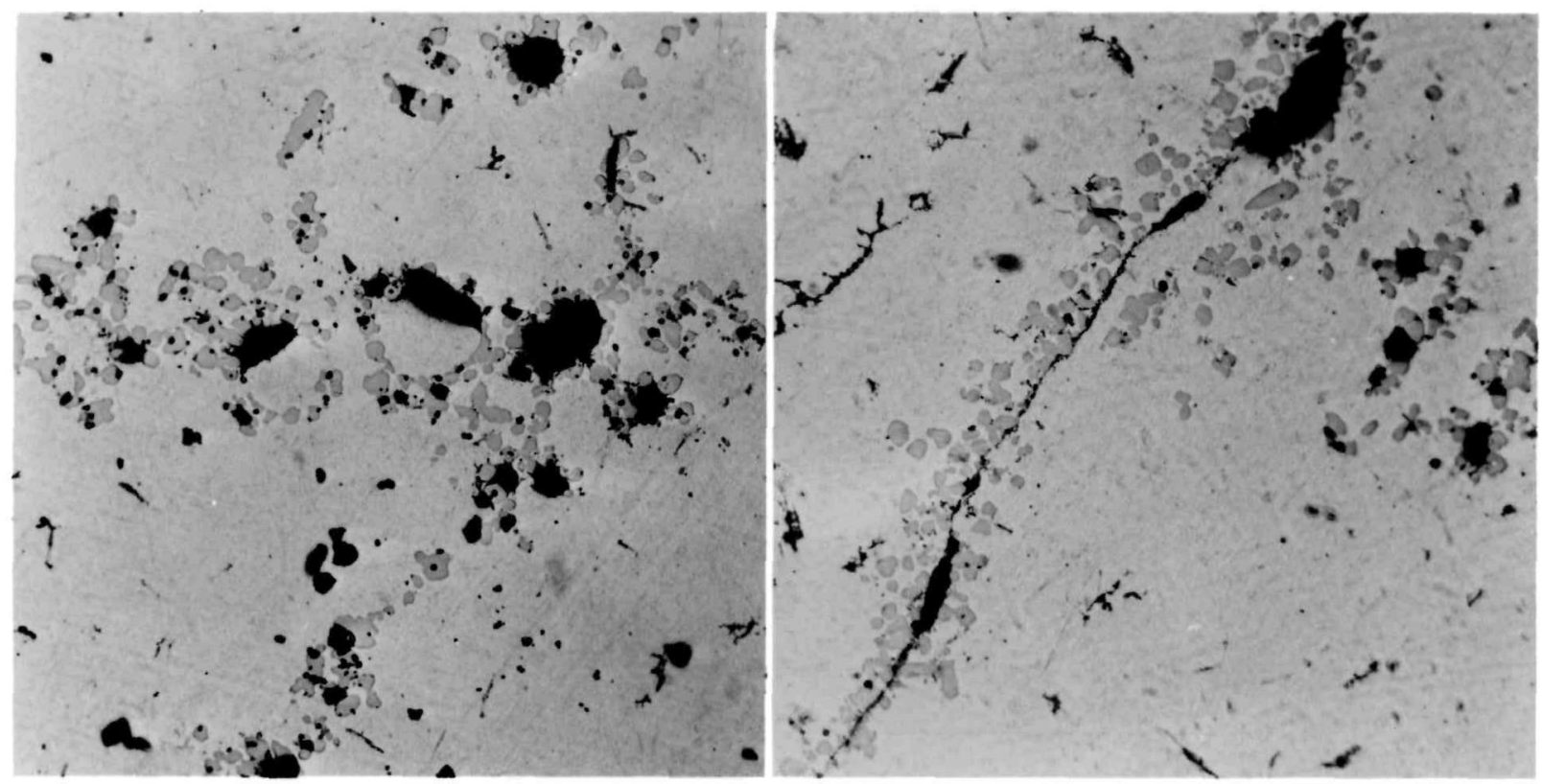

FIGURE 66

Different Configurations of PuN Inclusions at Top of Cast Billet 18-12-4A, $250 \mathrm{X}$. 


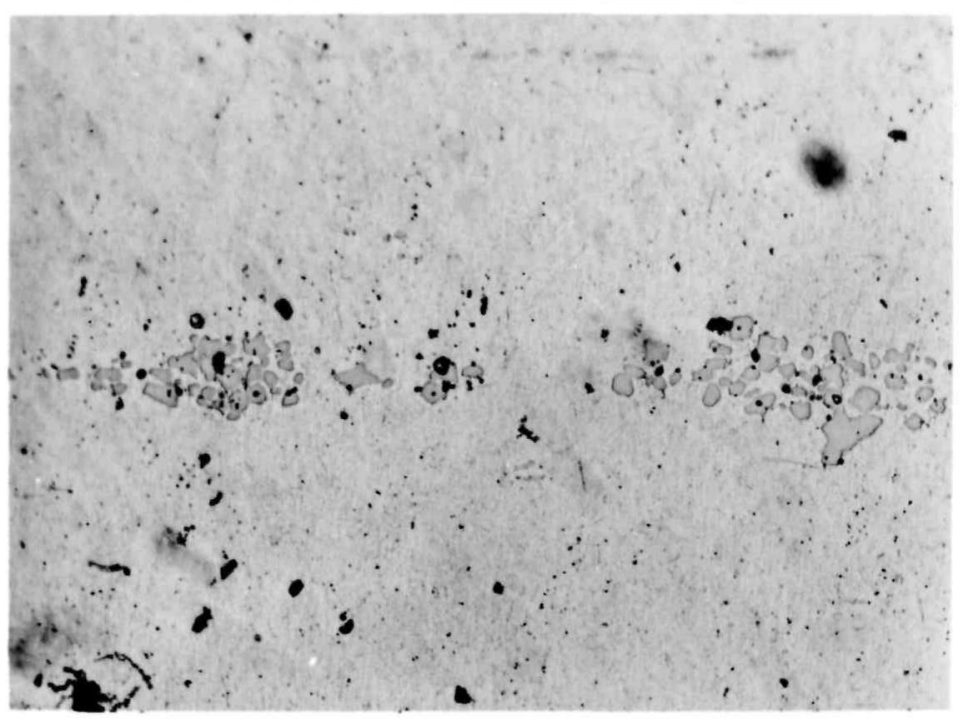

FIGURE 67

Plutonium Nitride Aligned in Extrusion Direction of Rod 18-12-4A, 250X. As Polished Surface, Bright Field, 250X.

Extrusion Direction

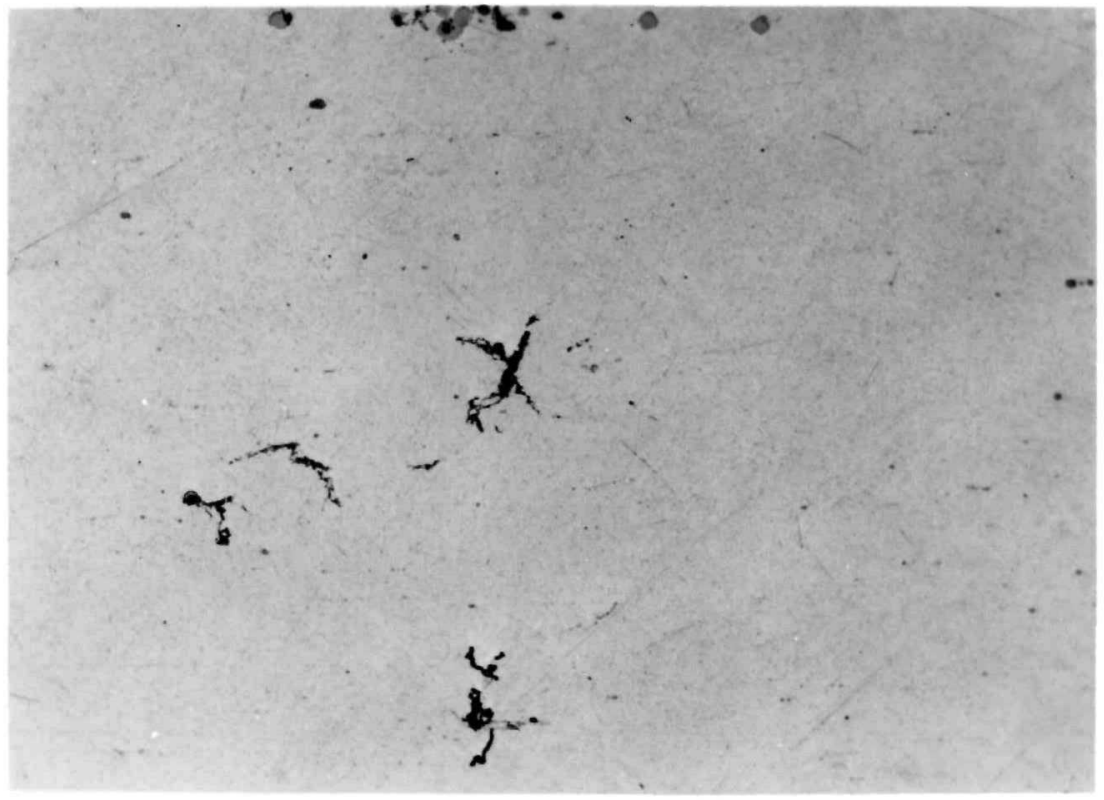

FIGURE 68

Randomly Oriented Microcracks in Extruded Rod 18-15-4A, 250X. 
Rod Periphery

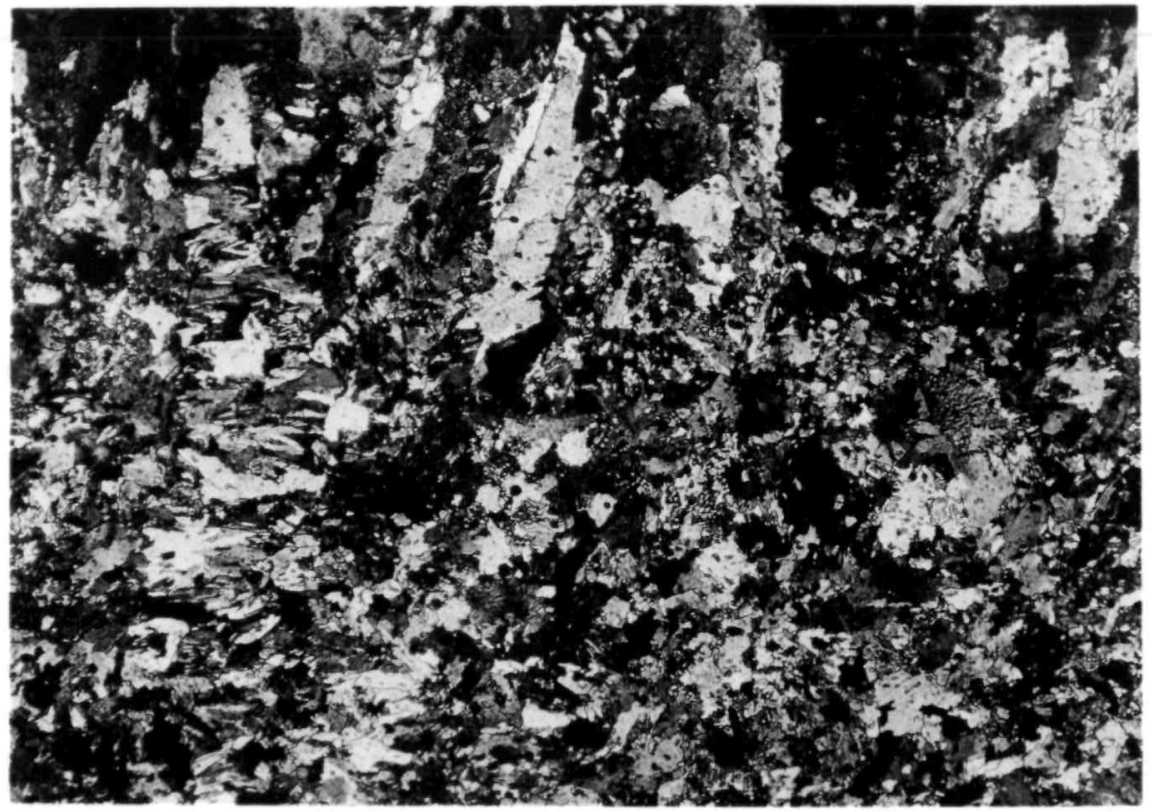

FIGURE 69

Columnar Grain Structure Existing at Periphery of Beta Extruded Rod. Transverse to Extrusion Direction, 100X.
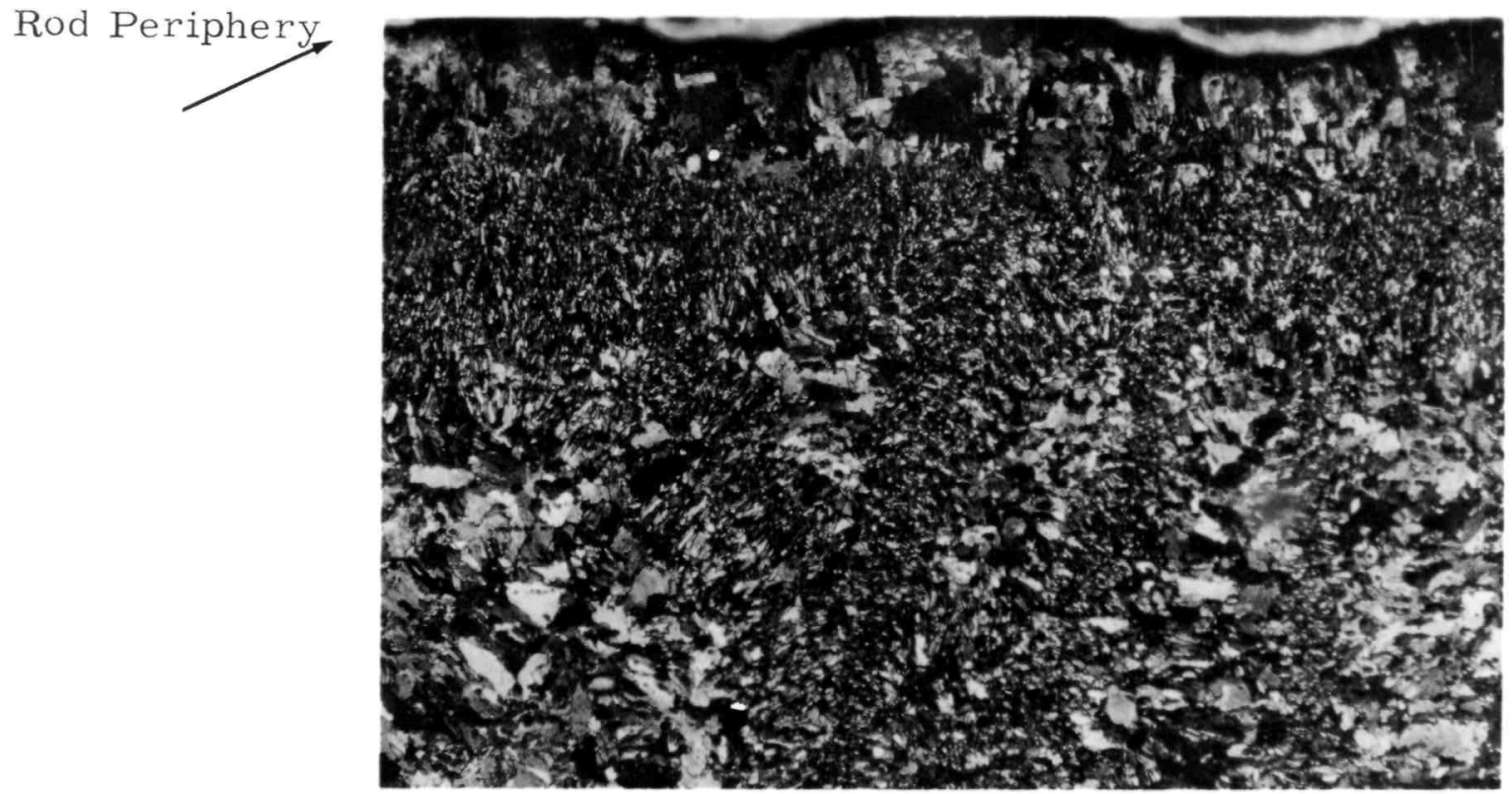

\section{FIGURE 70}

Banded Structure in Beta Extruded Rod. Note Coarse Grained Periphery, Fine Grained Layer, Then Fine and Coarse Grained Regions Tending to Align in Radial Direction. Transverse to Extrusion Direction, 100X. 


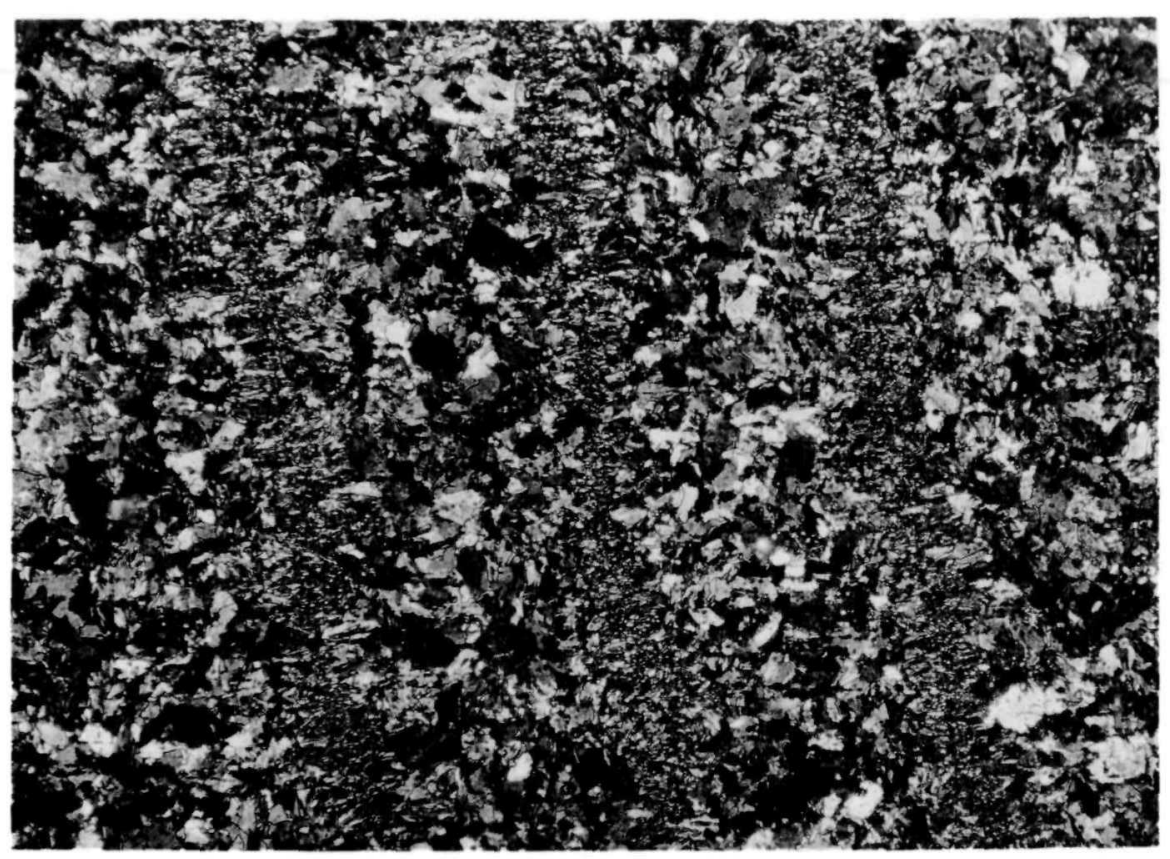

FIGURE 71

Banded Structure Existing in Beta Extruded Rod. Fine Grain Size -0.0062 $\mathrm{mm}$, Coarse Grain Size $-0.025 \mathrm{~mm}$. Transverse to Extrusion Direction, 100X.

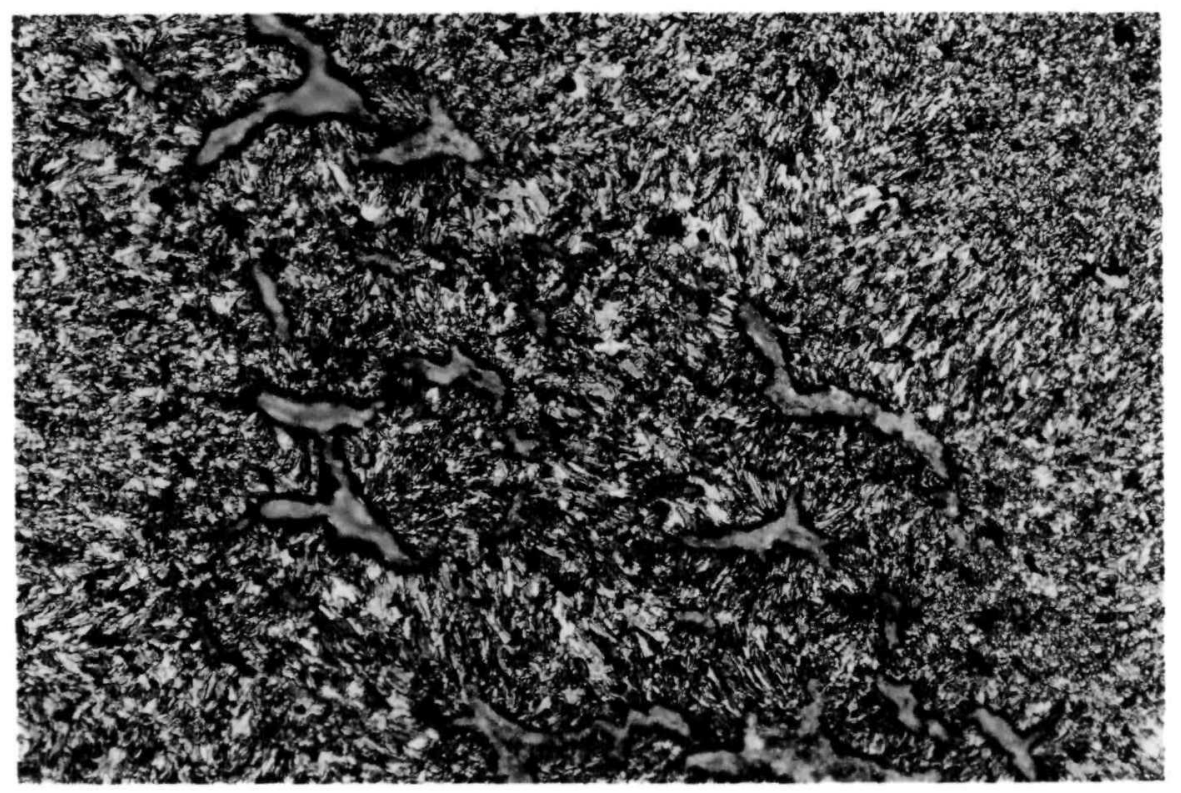

FIGURE 72

Columnar Grains Radiating from Microcracks. Transverse to Extrusion Direction, 100X. 


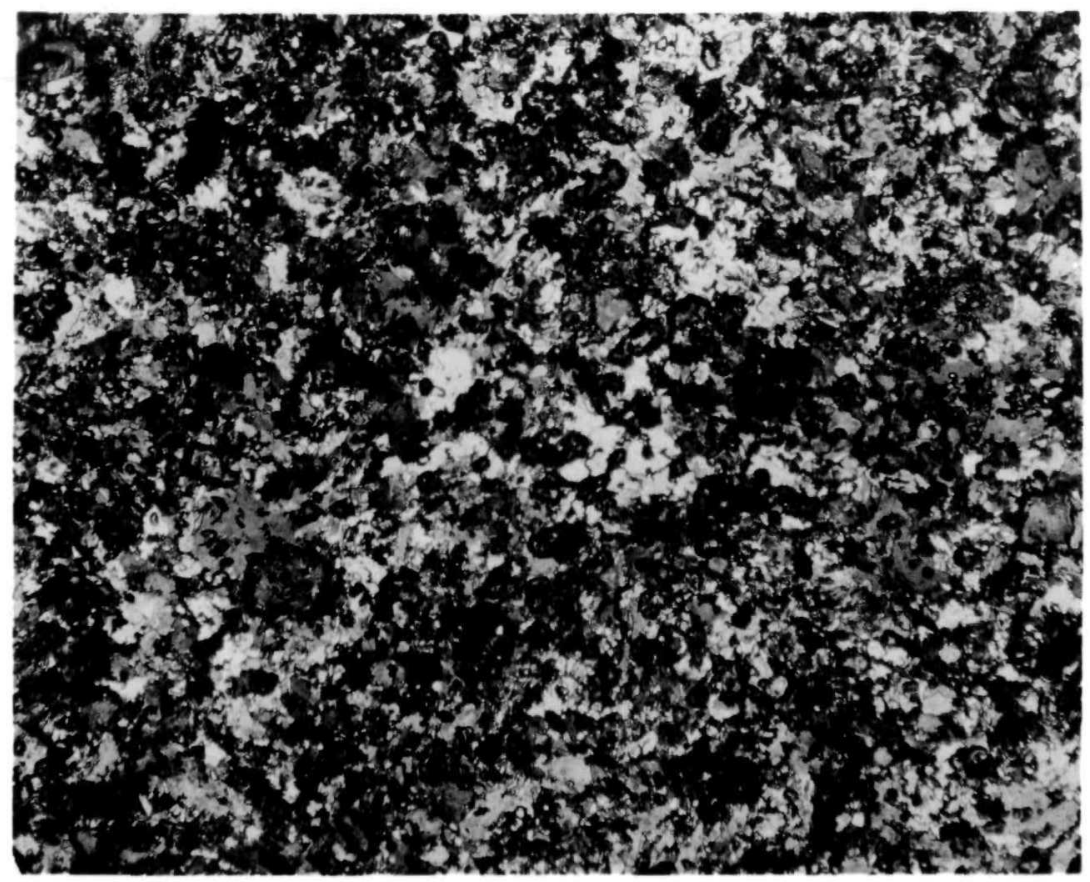

FIGURE 73

As Cast Grain Structure Prior to Beta Extrusion. Grain Size $-0.023 \mathrm{~mm}$. $100 \mathrm{X}$.

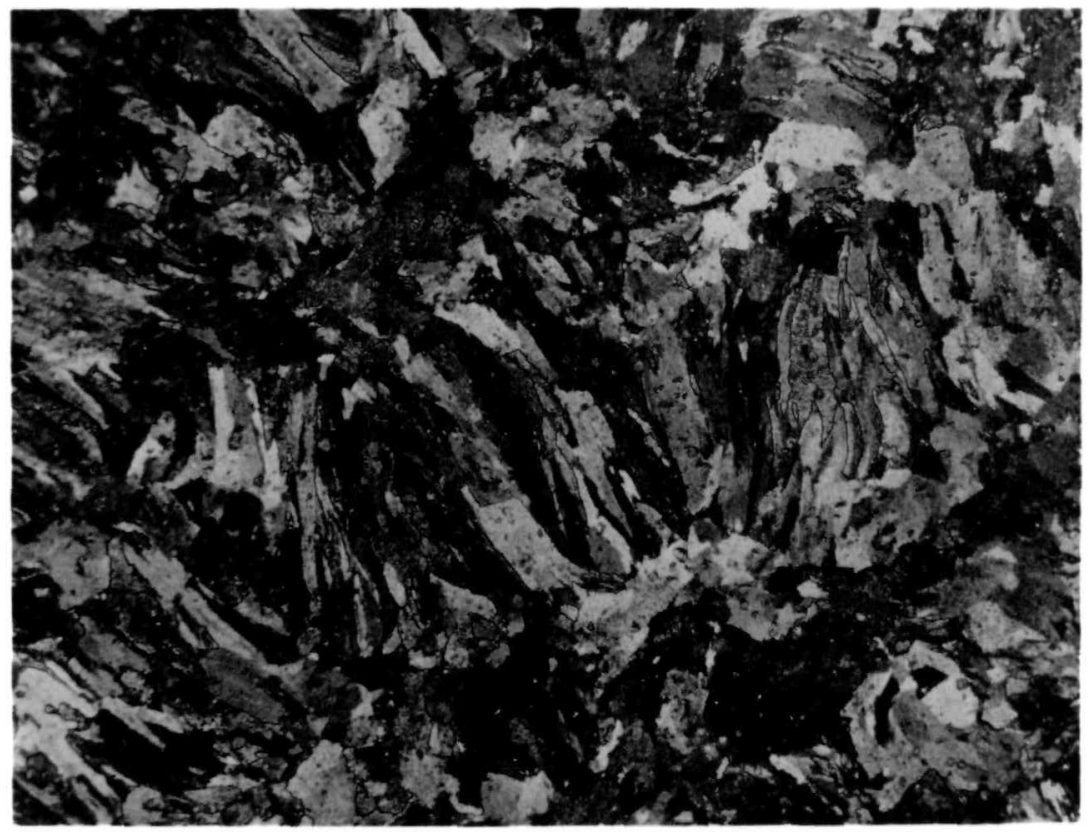

FIGURE 74

Columnar Grains Aligned in a Swirly Pattern in Gamma Extruded Rods 18-12-3C and 19-1-4, Grain Size - 0.028 mm. Transverse to Extrusion Direction, $250 \mathrm{x}$. 
Extrusion Direction

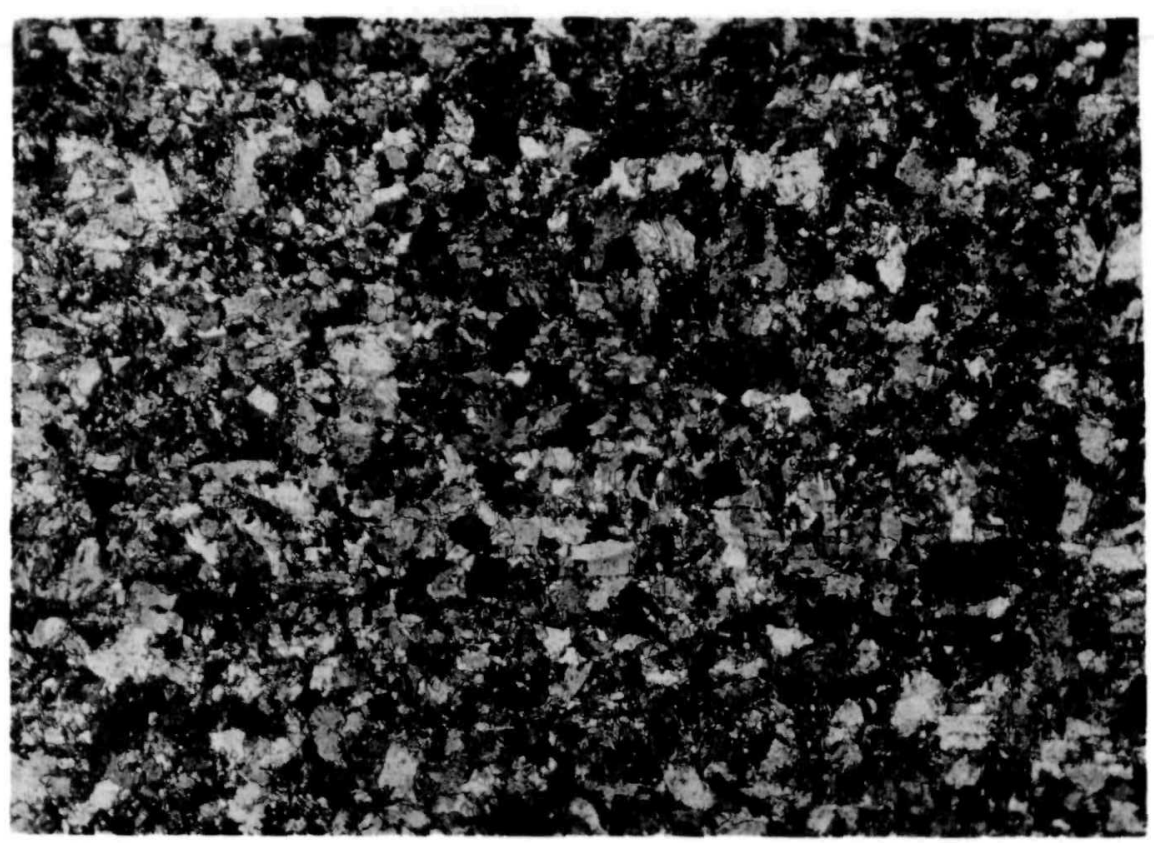

\section{FIGURE 75}

Non-alignment of Grains in Extrusion Direction of Gamma Extruded Rod 19-1-4, Grain Size - 0.040 mm, 100X.

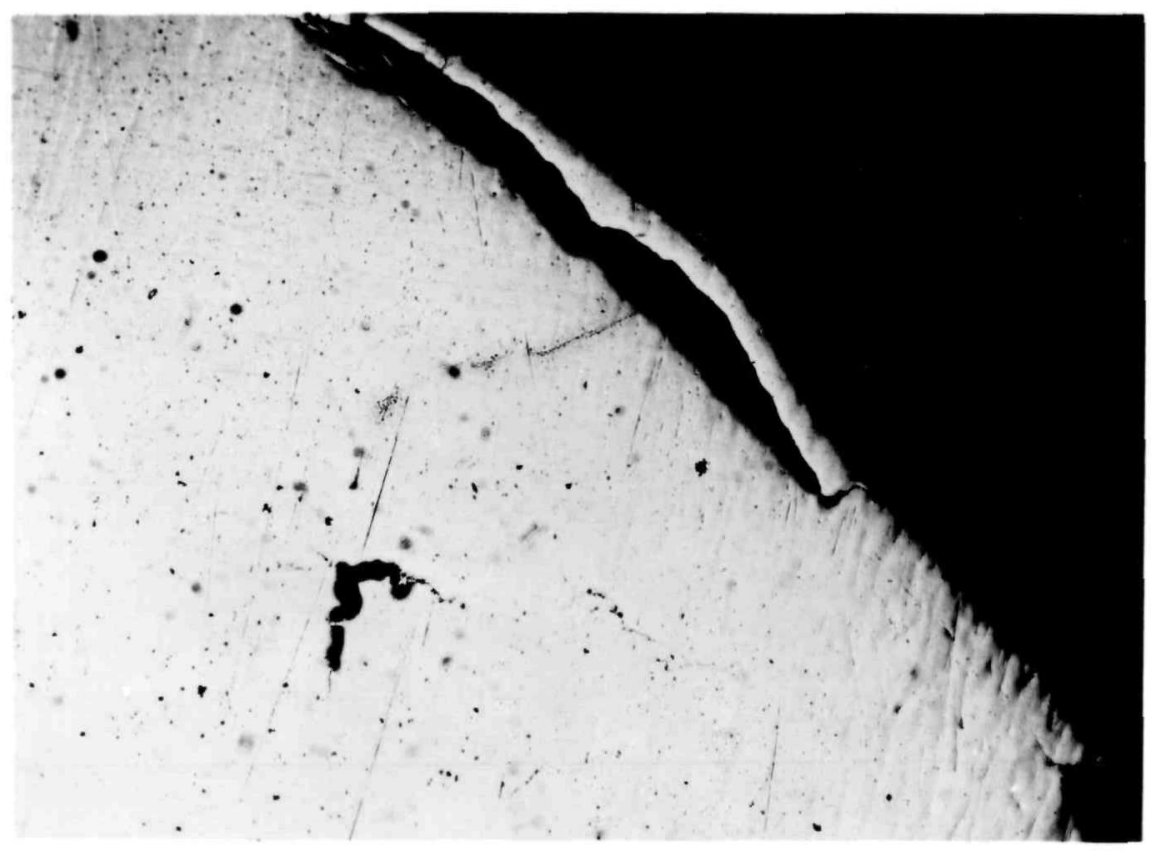

\section{FIGURE 76}

Blister on Periphery of Gamma Extruded Rod Near Butt End, Transverse to Extrusion Direction, 50X. 
TABLE I

CHEMICAL ANALYSIS(1), DENSITY AND GRAIN SIZE ${ }^{(2)}$ OF PLUTONIUM USED IN TENSILE STUDY

\begin{tabular}{|c|c|c|c|c|c|c|c|c|c|c|c|c|c|c|}
\hline & $\mathrm{Al}$ & $\mathrm{Ca}$ & $\mathrm{Cr}$ & $\mathrm{Cu}$ & $\mathrm{Fe}$ & $\mathrm{Mg}$ & $\mathrm{Mn}$ & $\underline{\mathrm{Ni}}$ & $\underline{\mathrm{Si}}$ & $\mathrm{C}$ & Total & $\begin{array}{l}\text { Density } \\
\text { (g/cc) }\end{array}$ & $\begin{array}{l}\text { As Cast } \\
\text { Grain Size } \\
\mathrm{mm} \\
\end{array}$ & $\begin{array}{c}\text { Number of } \\
\text { Samples }\end{array}$ \\
\hline Min & 3 & 2 & 5 & 2 & 51 & 2 & 10 & 2 & 1 & 40 & - & 19.43 & 0.024 & - \\
\hline $\operatorname{Max}$ & 40 & 16 & 100 & 30 & 1175 & 20 & 100 & 50 & 20 & 290 & - & 19. 60 & 0.070 & - \\
\hline Avg & 14 & 5 & 22 & 7 & 252 & 15 & 47 & 19 & 3 & 136 & 520 & 19.53 & 0.046 & 21 \\
\hline
\end{tabular}


TABLE II

EFFECT OF TEMPERATURE ON TENSILE PROPERTIES OF ALPHA PHASE PLUTONIUM ${ }^{(1)}$

\begin{tabular}{|c|c|c|c|c|c|c|c|}
\hline & $\begin{array}{l}\text { Test } \\
\text { Temp. } \\
\text { (C) }\end{array}$ & $\begin{array}{l}\text { Ultimate } \\
\text { Strength } \\
\text { (psi) }\end{array}$ & $\begin{array}{l}0.01 \% \text { Yield } \\
\text { Strength } \\
\text { (psi) }\end{array}$ & $\begin{array}{l}\text { Modulus of } \\
\text { Elasticity } \\
\left(10^{6} \text { psi) }\right.\end{array}$ & $\begin{array}{l}\text { Elongation }(2) \\
\text { Per Cent }\end{array}$ & $\begin{array}{l}\text { Reduction } \\
\text { In Area } \\
\text { Per Cent }\end{array}$ & $\begin{array}{l}\text { Number o } \\
\text { Samples } \\
\text { Tested }\end{array}$ \\
\hline $\begin{array}{l}\text { Min } \\
\operatorname{Max} \\
\text { Avg }\end{array}$ & -30 & $\begin{array}{l}52,500 \\
63,300 \\
57,300\end{array}$ & $\begin{array}{l}46,700 \\
56,800 \\
50,300\end{array}$ & $\begin{array}{l}14.0 \\
15.2 \\
14.7(12.7\end{array}$ & $\begin{array}{r}0.016 \\
0.020 \\
0.018\end{array}$ & $\begin{array}{l}- \\
-\end{array}$ & 4 \\
\hline $\begin{array}{l}\text { Min } \\
\text { Max } \\
\text { Avg }\end{array}$ & 30 & $\begin{array}{l}47,800 \\
56,800 \\
50,900\end{array}$ & $\begin{array}{l}28,200 \\
35,600 \\
32,100\end{array}$ & $\begin{array}{l}13.5 \\
14.8 \\
14.3\end{array}$ & $\begin{array}{l}0.054 \\
0.077 \\
0.068\end{array}$ & $\begin{array}{l}- \\
-\end{array}$ & 5 \\
\hline $\begin{array}{l}\text { Min } \\
\text { Max } \\
\text { Avg }\end{array}$ & 70 & $\begin{array}{l}42,900 \\
44,600 \\
43,800\end{array}$ & $\begin{array}{l}14,900 \\
15,600 \\
15,200\end{array}$ & $\begin{array}{l}12.6 \\
12.7 \\
12.6\end{array}$ & $\begin{array}{l}0.41 \\
0.45 \\
0.43\end{array}$ & $\begin{array}{l}- \\
-\end{array}$ & 2 \\
\hline $\begin{array}{l}\text { Min } \\
\text { Max } \\
\text { Avg }\end{array}$ & 100 & $\begin{array}{l}29,000 \\
3 \hat{9}, 600 \\
34,800\end{array}$ & $\begin{array}{l}11,800 \\
15,200 \\
13,600\end{array}$ & $\begin{array}{r}8.5 \\
11.5 \\
9.8(9.2)\end{array}$ & 3) $\begin{array}{l}0.91 \\
1.08 \\
1.00\end{array}$ & $\begin{array}{l}- \\
-\end{array}$ & 5 \\
\hline $\begin{array}{l}\text { Min } \\
\text { Max } \\
\text { Avg }\end{array}$ & 110 & $\overline{-}$ & $\begin{array}{l}11,600 \\
13,000 \\
12,300\end{array}$ & $\begin{array}{r}9.0 \\
10.9 \\
10.0\end{array}$ & $\begin{array}{l}- \\
- \\
-\end{array}$ & $\begin{array}{l}- \\
- \\
-\end{array}$ & 2 \\
\hline
\end{tabular}

(1) Testing speed: 0.015 inches/minute

(2) Based on one inch gage length

(3) Determined with Martins Extensometer 
TABLE III

EFFECT OF TEMPERATURE ON TENSILE PROPERTIES OF BETA, GAMMA AND DEL TA PHASES ${ }^{(1)}$

\begin{tabular}{|c|c|c|c|c|c|c|c|c|}
\hline & $\begin{array}{l}\text { Test } \\
\text { Temp. } \\
\text { (C) }\end{array}$ & $\begin{array}{l}\text { Ultimate } \\
\text { Strength } \\
\text { (psi) }\end{array}$ & $\begin{array}{l}\text { Yield } \\
\text { Strength } \\
\quad \text { (psi) }\end{array}$ & $\begin{array}{l}\text { Modulus of } \\
\text { Elasticity } \\
\text { (106 psi) }\end{array}$ & $\begin{array}{l}\text { Elongation } \\
\text { Per Cent }\end{array}$ & $\begin{array}{l}\text { Reduction } \\
\text { In Area } \\
\text { Per Cent }\end{array}$ & $\begin{array}{l}\text { Number of } \\
\text { Samples } \\
\text { Tested }\end{array}$ & Phase \\
\hline $\begin{array}{l}\text { Min } \\
\text { Max } \\
\text { Avg }\end{array}$ & 130 & $\begin{array}{l}11,700 \\
12,500 \\
12,100\end{array}$ & $\begin{array}{l}10,240 \\
10,570 \\
10,400\end{array}$ & $\begin{array}{l}\text { 2. } 0 \\
\text { 3. } 9 \\
\text { 3. } 0\end{array}$ & $\begin{array}{l}272.0 \\
316.0 \\
294.0\end{array}$ & $\begin{array}{l}100.0 \\
100.0 \\
100.0\end{array}$ & 2 & Beta \\
\hline $\begin{array}{l}\text { Min } \\
\text { Max } \\
\text { Avg }\end{array}$ & 160 & $\begin{array}{l}5,500 \\
5,830 \\
5,620\end{array}$ & $\begin{array}{l}3,720 \\
4,380 \\
3,950\end{array}$ & $\begin{array}{l}- \\
- \\
-\end{array}$ & $\begin{array}{l}519.0 \\
621.8 \\
570.4\end{array}$ & $\begin{array}{l}100.0 \\
100.0 \\
100.0\end{array}$ & 3 & Beta \\
\hline $\begin{array}{l}\text { Min } \\
\text { Max } \\
\text { Avg }\end{array}$ & 180 & $\begin{array}{l}3,550 \\
3,600 \\
3,580\end{array}$ & $\begin{array}{l}2,540 \\
2,600 \\
2,620\end{array}$ & $\begin{array}{l}- \\
- \\
-\end{array}$ & $\begin{array}{l}481.3 \\
525.0 \\
503.2\end{array}$ & $\begin{array}{l}100.0 \\
100.0 \\
100.0\end{array}$ & 2 & Beta \\
\hline $\begin{array}{l}\text { Min } \\
\text { Max } \\
\text { Avg }\end{array}$ & 190 & $\begin{array}{l}2,950 \\
3,590 \\
3,280\end{array}$ & $\begin{array}{l}1,730 \\
2,630 \\
2,210\end{array}$ & $\begin{array}{l}1.4 \\
1.7 \\
1.6\end{array}$ & $\begin{array}{l}271.5 \\
406.2 \\
325.9\end{array}$ & $\begin{array}{r}93.5 \\
100.0 \\
97.8\end{array}$ & 6 & Beta \\
\hline $\begin{array}{l}\text { Min } \\
\text { Max } \\
\text { Avg }\end{array}$ & 200 & $\begin{array}{l}2,730 \\
3,390 \\
2,940\end{array}$ & $\begin{array}{l}1,950 \\
2,360 \\
2,190\end{array}$ & $\begin{array}{l}- \\
-\end{array}$ & $\begin{array}{r}93.8 \\
151.0 \\
121.0\end{array}$ & $\begin{array}{l}60.2 \\
97.1 \\
82.1\end{array}$ & 6 & Beta \\
\hline $\begin{array}{l}\text { Min } \\
\text { Max } \\
\text { Avg }\end{array}$ & 230 & $\begin{array}{l}3,330 \\
4,990 \\
4,420\end{array}$ & $\begin{array}{l}3,250 \\
4,210 \\
3,860\end{array}$ & $\begin{array}{l}1.8 \\
1.8 \\
1.8\end{array}$ & $\begin{array}{l}37.5 \\
65.8 \\
50.0\end{array}$ & $\begin{array}{l}61.0 \\
92.5 \\
75.0\end{array}$ & 7 & Gamma \\
\hline
\end{tabular}




\section{TABLE III (Contd.)}

\begin{tabular}{|c|c|c|c|c|c|c|c|c|}
\hline & $\begin{array}{l}\text { Test } \\
\text { Temp. } \\
\text { (C) }\end{array}$ & $\begin{array}{l}\text { Ultimate } \\
\text { Strength } \\
\text { (psi) }\end{array}$ & $\begin{array}{l}\text { Yield } \\
\text { Strength } \\
(\mathrm{psi})\end{array}$ & $\begin{array}{l}\text { Modulus of } \\
\text { Elasticity } \\
\left(10^{6} \text { psi) }\right.\end{array}$ & $\begin{array}{l}\text { Elongation } \\
\text { Per Cent }\end{array}$ & $\begin{array}{l}\text { Reduction } \\
\text { In Area } \\
\text { Per Cent }\end{array}$ & $\begin{array}{l}\text { Number of } \\
\text { Samples } \\
\text { Tested }\end{array}$ & Phase \\
\hline $\begin{array}{l}\text { Min } \\
\text { Max } \\
\text { Avg }\end{array}$ & 265 & $\begin{array}{l}2,500 \\
4,750 \\
3,470\end{array}$ & $\begin{array}{l}2,340 \\
3,660 \\
2,900\end{array}$ & $\begin{array}{l}- \\
-\end{array}$ & $\begin{array}{l}33.0 \\
84.4 \\
57.2\end{array}$ & $\begin{array}{l}64.0 \\
84.7 \\
77.0\end{array}$ & 7 & Gamma \\
\hline $\begin{array}{l}\text { Min } \\
\text { Max } \\
\text { Avg }\end{array}$ & 300 & $\begin{array}{l}1,540 \\
2,630 \\
2,020\end{array}$ & $\begin{array}{l}1,360 \\
2,100 \\
1,650\end{array}$ & $\begin{array}{l}0.9 \\
1.2 \\
1.0\end{array}$ & $\begin{array}{l}37.5 \\
68.8 \\
50.1\end{array}$ & $\begin{array}{l}57.9 \\
98.6 \\
82.8\end{array}$ & 8 & Gamma \\
\hline $\begin{array}{l}\text { Min } \\
\text { Max } \\
\text { Avg }\end{array}$ & 325 & $\begin{array}{l}837 \\
953 \\
895\end{array}$ & $\begin{array}{l}731 \\
848 \\
790\end{array}$ & $\begin{array}{l}0.35 \\
0.40 \\
0.38\end{array}$ & $\begin{array}{l}65.8 \\
68.8 \\
67.3\end{array}$ & $\begin{array}{l}97.5 \\
98.4 \\
98.0\end{array}$ & 2 & Delta \\
\hline
\end{tabular}

(1) Testing speed: 0.015 inches/minute

(2) Based on one inch gage length 


\section{TABLE IV}

EFFECT OF TESTING SPEED ON ALPHA PHASE STRENGTH

\begin{tabular}{|c|c|c|c|c|c|c|c|c|c|c|c|}
\hline \multirow[b]{2}{*}{$\begin{array}{l}\text { Testing } \\
\text { Speed } \\
\text { in } / \mathrm{min} \\
\end{array}$} & \multicolumn{4}{|c|}{$30^{\circ} \mathrm{C}$} & \multicolumn{7}{|c|}{$110^{\circ} \mathrm{C}$} \\
\hline & $\begin{array}{c}\text { Sample } \\
\text { No. }\end{array}$ & $\begin{array}{l}\text { Density } \\
\text { (g/cc) }\end{array}$ & $\begin{array}{c}\text { Total } \\
\text { Impurity } \\
\text { (ppm) }\end{array}$ & $\begin{array}{l}\text { Ultimate } \\
\text { Strength } \\
\text { (psi) } \\
\end{array}$ & $\begin{array}{c}0.01 \% \\
\text { Yield } \\
\text { Strength } \\
\text { (psi) }\end{array}$ & $\begin{array}{c}\text { Sample } \\
\text { No. }\end{array}$ & $\begin{array}{l}\text { Density } \\
\text { (g/cc) }\end{array}$ & $\begin{array}{c}\text { Total } \\
\text { Impurity } \\
\text { (ppm) }\end{array}$ & $\begin{array}{l}\text { Ultimate } \\
\text { Strength } \\
\text { (psi) }\end{array}$ & $\begin{array}{c}0.01 \% \\
\text { Yield } \\
\text { Strength } \\
\text { (psi) }\end{array}$ & \\
\hline 0.002 & $\begin{array}{l}19-9-1 \mathrm{~A} \\
19-9-1 \mathrm{~B}\end{array}$ & $\begin{array}{l}19.56 \\
19.56\end{array}$ & $\begin{array}{l}439 \\
439\end{array}$ & $\begin{array}{l}42,600 \\
44,800\end{array}$ & $\begin{array}{l}23,000 \\
24,600\end{array}$ & $\begin{array}{l}19-4-11^{(1)} \\
19-4-10\end{array}$ & $\begin{array}{l}19.53 \\
19.53\end{array}$ & $\begin{array}{l}384 \\
384\end{array}$ & $\begin{array}{l}21,500 \\
23,200\end{array}$ & 7800 & \\
\hline 0.015 & $\begin{array}{l}19-11-2 G \\
19-5-8 \mathrm{~N} \\
19-4-2 \mathrm{P} \\
19-3-4 \mathrm{E} \\
19-9-1 \mathrm{C} \\
19-3-4 \mathrm{~F}\end{array}$ & $\begin{array}{l}19.47 \\
19.60 \\
19.43 \\
19.51 \\
19.56 \\
19.51\end{array}$ & $\begin{array}{r}1476 \\
377 \\
780 \\
328 \\
439 \\
328\end{array}$ & $\begin{array}{c}51,300 \\
56,800 \\
50,500 \\
47,800 \\
--- \\
48,100\end{array}$ & $\begin{array}{c}35,300 \\
35,600 \\
--- \\
-- \\
29,300 \\
28,200\end{array}$ & $\begin{array}{c}19-3-4 \mathrm{G} \\
19-3-4 \mathrm{H} \\
-\end{array}$ & $\begin{array}{c}19.51 \\
19.51 \\
\ldots--\end{array}$ & $\begin{array}{l}328 \\
328 \\
---\end{array}$ & --- & $\begin{array}{c}13,000 \\
11,700 \\
-\end{array}$ & $\stackrel{1}{1}$ \\
\hline 0.060 & $\begin{array}{l}19-9-2 \mathrm{E} \\
19-9-4 \mathrm{~L} \\
19-9-6 \mathrm{U}\end{array}$ & $\begin{array}{l}19.49 \\
19.53 \\
19.52\end{array}$ & $\begin{array}{l}380 \\
468 \\
616\end{array}$ & $\begin{array}{l}54,800 \\
49,200 \\
50,700\end{array}$ & $\begin{array}{l}31,800 \\
29,700 \\
25,700\end{array}$ & $\begin{array}{l}19-5-3 \mathrm{~A} \\
19-5-3 \mathrm{~B} \\
19-4-1 \mathrm{M}\end{array}$ & $\begin{array}{l}19.48 \\
19.48 \\
19.53\end{array}$ & $\begin{array}{l}504 \\
504 \\
384\end{array}$ & $\begin{array}{l}33,400 \\
37,400 \\
32,600\end{array}$ & $\begin{array}{c}12,800 \\
13,400\end{array}$ & 7 \\
\hline 0.250 & $\begin{array}{l}19-9-3 \mathrm{~K} \\
19-9-5 \mathrm{Q} \\
19-9-6 \mathrm{~V}\end{array}$ & $\begin{array}{l}19.56 \\
19.55 \\
19.52\end{array}$ & $\begin{array}{l}295 \\
616 \\
616\end{array}$ & $\begin{array}{l}47,000 \\
56,500 \\
54,000\end{array}$ & $\begin{array}{l}28,100 \\
36,600\end{array}$ & $\begin{array}{l}19-5-3 C \\
19-5-3 D \\
19-4-1 L\end{array}$ & $\begin{array}{l}19.48 \\
19.58 \\
19.53\end{array}$ & $\begin{array}{l}504 \\
504 \\
384\end{array}$ & $\begin{array}{l}39,500 \\
38,600 \\
33,300\end{array}$ & -- & \\
\hline 1. 0 & $\begin{array}{l}19-9-6 X \\
19-9-6 Z\end{array}$ & $\begin{array}{l}19.52 \\
19.52\end{array}$ & $\begin{array}{l}616 \\
616\end{array}$ & $\begin{array}{l}51,700 \\
46,800\end{array}$ & $=-$ & $\begin{array}{l}19-5-6 G \\
19-5-5 E\end{array}$ & $\begin{array}{l}19.57 \\
19.60\end{array}$ & $\begin{array}{l}486 \\
295\end{array}$ & $\begin{array}{c}31,500 \\
29,800\end{array}$ & $\ldots$ & \\
\hline
\end{tabular}

(1) Unlike the specimens tested at faster speeds at this temperature, the load dropped off gradually just before failure indicating that some necking may have taken place.

However, the degree of necking was so small that it could not be measured with a micrometer caliper. 
TABLE V

EFFECT OF TESTING SPEED ON BETA AND GAMMA PHASE TENSILE PROPERTIES

\section{Test
Speed}

Speed

0.002

0.015

0.060
0.250

0.250
1.00

0.002
0.015

0.060

0.250
1.00

0.002

0.002
0.015
0.060

0.060
0.250

1.00

0.002

0.015
0.060

0.060

0.250

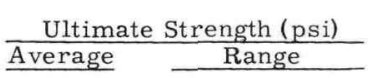

7,000

12,100

17,300

18,800

\section{3,400}

3,400
5,600

8,500

12,400

18,700

1, $700-12,500$

700-12,

$27,800-29,800$

$5,500-5,830$

$8,170-8,840$

$11,900-12,900$

$$
\begin{array}{r}
2,400 \\
3,280 \\
5,230 \\
8,180 \\
10,600
\end{array}
$$

2, $950-3,590$
$4,970-5,510$
$6,740-9,880$
$10,000-11,500$

3,250
3,400
3,910
4,500
4,940

$--10-4,750$
$3,280-4,240$
$3,710-5,200$
$4,160-5,350$

\begin{tabular}{r} 
Yie \\
\hline Average \\
\hline 3,920 \\
10,400 \\
--- \\
16,900 \\
21,700 \\
\\
2,550 \\
3,950 \\
6,200 \\
9,900 \\
15,200 \\
\\
\\
1,520 \\
2,210 \\
4,030 \\
5,890 \\
7,820 \\
\\
2,280 \\
2,750 \\
3,300 \\
4,030 \\
4,720
\end{tabular}

Yield Strength (psi)
$\frac{\text { Range }}{\mathrm{Be}}$

10, $200-10,600$

$19,100-24,300$ Beta Phase - $160 \mathrm{C}$

\section{3, $720-4,38$}

$5,920-6,480$

$9,600-10,200$

$14,800-15,700$

570.4

360.9

251. 6

$1,730-2,630 \quad 325.9$

$3,610-4,410$
$4,070-8,360$

325.9
331.5

$6,370-9,280$

243.5

Gamma Phase - 265 C

$340-3,650$

$2,340-3,650$

$3,520-4,600$
$4,050-5,070$

75. 0

59.3

49.6
42.7
44.8
Elongation $^{(1)}(\%)$ $\mathrm{C}$ Range

272. $0-\overline{-}-316$.

$2.0-316.0$
---
---
--

$519, \overline{0-6}$

$315.6-406.2$

196. $9-306.2$
$78.1-143.7$

\section{$271 . \overline{5--}-406.2$}

$$
\text { --- }
$$

$33 . \overline{---}$

33. $0-84.4$

$40.7-64.1$

37. $5-53.2$
Reduction in Area (\%) Average Range

$100^{---}$

100
100
55

55.2
35.5

---

---

$100^{---}$

100

98.6
70.0

---

8. $3-98,9$

61. $1-79.0$

97.8
100.0

100.0

100.0

0.

90.9
79.6

68.6

69.2
69.3

93. $\overline{5-100}$

---

71. $2-84.7$

$71.2-84.7$

52. $4-99.0$

38. $0-93.2$
Number

of Samples

Tested

$$
\begin{aligned}
& - \\
& 2 \\
& 1 \\
& 1 \\
& 2 \\
& \\
& 1 \\
& 3 \\
& 2 \\
& 2 \\
& 2
\end{aligned}
$$

(1) Based on one-inch gage length 


\section{TABLE VI}

CHEMICAL ANALYSIS, ${ }^{(1)}$ DENSITY AND AS-CAST GRAIN SIZE ${ }^{(2)}$ OF PLUTONIUM STUDIED

$$
\text { High Density }{ }^{(4)}
$$

\begin{tabular}{|c|c|c|c|c|c|c|c|c|c|c|c|c|c|c|c|c|c|}
\hline & $\mathrm{A} 1$ & $\mathrm{Ca}$ & $\mathrm{Cr}$ & $\mathrm{Cu}$ & $\mathrm{Fe}$ & $\mathrm{Mg}$ & Mn & $\mathrm{Ni}$ & $\mathrm{Si}$ & C & $\mathrm{O}^{(3)}$ & $H^{(3}$ & $\mathrm{N}^{(3)}$ & Total & $\begin{array}{r}\text { Density } \\
(\mathrm{g} / \mathrm{cc})\end{array}$ & $\begin{array}{c}\text { Grain } \\
\text { Size(mm) }\end{array}$ & $\begin{array}{c}\text { No. of } \\
\text { Samples }\end{array}$ \\
\hline Min. & 2 & 3 & 1 & 2 & 50 & 10 & 5 & 1 & 1 & 58 & 81 & 1 & 1 & 415 & 19.52 & 0.024 & -- \\
\hline Max. & 20 & 50 & 200 & 20 & 500 & 50 & 200 & 200 & 20 & 210 & 190 & 13 & 40 & 1024 & 19. 59 & 0.050 & -- \\
\hline Avg. & 6 & 8 & 34 & 10 & 216 & 22 & 45 & 38 & 5 & 140 & 132 & 6 & 11 & 666 & 19.55 & 0.040 & 14 \\
\hline & & & & & & & & & & $y^{(5)}$ & & & & & & & \\
\hline Min. & 2 & 5 & 2 & 5 & 100 & 5 & 10 & 20 & 1 & 60 & 64 & 1 & 1 & 457 & 19. 34 & 0.016 & -- \\
\hline Max. & 13 & 13 & 100 & 20 & 2000 & 200 & 500 & 200 & 50 & 600 & 200 & 11 & 10 & 3468 & 19.48 & 0.053 & -- \\
\hline Avg. & 4 & 8 & 51 & 14 & 483 & 62 & 97 & 97 & 28 & 172 & 123 & 8 & 4 & 1140 & 19.44 & 0.033 & 10 \\
\hline
\end{tabular}

(1) Reported in parts per million.

(2) Reported as average grain diameter in millimeters.

(3) The average for the $\mathrm{O}, \mathrm{H}$ and $\mathrm{N}$ impurities are based on 5 samples for the high density group and 7 samples for the low density group.

(4) Equal to or greater than $19.50 \mathrm{~g} / \mathrm{cc}$.

(5) Less than $19.50 \mathrm{~g} / \mathrm{cc}$. 
TABLE VII

COMPRESSION PROPERTIES OF PLUTONIUM ${ }^{(1)}$ AT 30 C

Density Less Than $19.50 \mathrm{~g} / \mathrm{cc}$

\begin{tabular}{|c|c|}
\hline $\begin{array}{l}\text { Specimen } \\
\text { Number }\end{array}$ & $\begin{array}{c}\text { Density } \\
(\mathrm{g} / \mathrm{cc})\end{array}$ \\
\hline $\begin{array}{l}17-12-1 \mathrm{G} 1 \\
17-12-1 \mathrm{G} 2\end{array}$ & $\begin{array}{l}19.42 \\
19.42\end{array}$ \\
\hline $18-1-1 \mathrm{~A}$ & 19. 34 \\
\hline $18-1-1 B$ & 19.47 \\
\hline $\begin{array}{l}18-1-4 G 1 \\
18-1-4 G 2\end{array}$ & $\begin{array}{l}19.43 \\
19.43\end{array}$ \\
\hline $\begin{array}{l}18-1-6 \mathrm{~L} 1 \\
18-1-6 \mathrm{~L} 2\end{array}$ & $\begin{array}{l}19.47 \\
19.47\end{array}$ \\
\hline $\begin{array}{l}18-1-7 \mathrm{M} 1 \\
18-1-7 \mathrm{M} 2\end{array}$ & $\begin{array}{l}19.43 \\
19.43\end{array}$ \\
\hline $\begin{array}{l}18-1-7 \mathrm{~N} 1 \\
18-1-7 \mathrm{~N} 2\end{array}$ & $\begin{array}{l}\text { 19. } 46 \\
19.46\end{array}$ \\
\hline AVERAGE(3) & 19.43 \\
\hline
\end{tabular}

\begin{tabular}{l}
$\begin{array}{c}\text { Ultimate } \\
\text { Strength } \\
\text { (psi) }\end{array}$ \\
\hline 178,600 \\
175,200 \\
163,900 \\
175,600 \\
177,000 \\
177,800 \\
156,600 \\
149,000 \\
163,200 \\
172,000 \\
165,600 \\
164,400 \\
168,500
\end{tabular}

\begin{tabular}{ccc}
$\begin{array}{c}\text { Yield } \\
\text { (psi) }\end{array}$ & & $\begin{array}{c}\text { Diamond } \\
\text { Pyramid } \\
\text { Hardness } \\
(10 \mathrm{~kg} \text { load })\end{array}$ \\
\cline { 1 - 1 }- & & 272 \\
- & & 272 \\
- & & 255 \\
- & & 265 \\
- & & 267 \\
- & & 265 \\
- & & 265 \\
- & & 256 \\
- & 256 \\
- & 275 \\
- & 275 \\
- & 260
\end{tabular}

Plastic Decrease In Length Prior To Failure (2)

Metal Group

$-\frac{1}{1}$

2

3

4

5

$-$

$-$

$-$

$-$

$-$ 
TABLE VII (Contd.)

Density Equal to or Greater Than $19.50 \mathrm{~g} / \mathrm{cc}$

\begin{tabular}{|c|c|c|c|c|c|c|}
\hline $\begin{array}{l}\text { Specimen } \\
\text { Number }\end{array}$ & $\begin{array}{l}\text { Density } \\
(\mathrm{g} / \mathrm{cc})\end{array}$ & $\begin{array}{l}\text { Ultimate } \\
\text { Strength } \\
\text { (psi) }\end{array}$ & $\begin{array}{l}\text { Yield } \\
\text { Strength } \\
\quad \text { (psi) }\end{array}$ & $\begin{array}{c}\text { Diamond } \\
\text { Pyramid } \\
\text { Hardness } \\
(10 \mathrm{~kg} \text { load })\end{array}$ & $\begin{array}{l}\text { Plastic Decrease } \\
\text { In Length Prior } \\
\text { To Failure (2) } \\
\text { Per Cent }\end{array}$ & $\begin{array}{l}\text { Metal } \\
\text { Group }\end{array}$ \\
\hline $\begin{array}{l}18-1-3 F 1 \\
18-1-3 F 2\end{array}$ & $\begin{array}{l}19.55 \\
19.55\end{array}$ & $\begin{array}{l}177,600 \\
175,600\end{array}$ & - & $\begin{array}{l}265 \\
265\end{array}$ & $\begin{array}{l}- \\
-\end{array}$ & 8 \\
\hline $\begin{array}{l}18-1-6 \mathrm{~K} 1 \\
18-1-6 \mathrm{~K} 2\end{array}$ & $\begin{array}{l}19.56 \\
19.56\end{array}$ & $\begin{array}{l}166,800 \\
169,000\end{array}$ & - & $\begin{array}{l}256 \\
256\end{array}$ & - & 9 \\
\hline $\begin{array}{l}18-8-1 \mathrm{D} 1 \\
18-8-1 \mathrm{D} 2\end{array}$ & $\begin{array}{l}19.55 \\
19.55\end{array}$ & $\begin{array}{l}168,200 \\
164,000\end{array}$ & $\begin{array}{l}102,400 \\
109,100\end{array}$ & $\begin{array}{l}- \\
-\end{array}$ & $\begin{array}{l}21.3 \\
18.6\end{array}$ & 10 \\
\hline $\begin{array}{l}18-8-4 P 1 \\
18-8-4 P 2\end{array}$ & $\begin{array}{l}19.56 \\
19.56\end{array}$ & $\begin{array}{l}184,000 \\
178,000\end{array}$ & $\begin{array}{l}103,200 \\
109,800\end{array}$ & $\begin{array}{l}259 \\
259\end{array}$ & $\begin{array}{l}24.0 \\
22.6\end{array}$ & 11 \\
\hline $\begin{array}{l}18-8-5 Q 1 \\
18-8-5 Q 2 \\
18-8-5 Q 3\end{array}$ & $\begin{array}{l}19.55 \\
19.55 \\
19.55\end{array}$ & $\begin{array}{l}183,000 \\
181,000 \\
189,000\end{array}$ & $\begin{array}{r}99,800 \\
112,700 \\
107,600\end{array}$ & $\begin{array}{l}- \\
- \\
-\end{array}$ & $\begin{array}{l}23.4 \\
23.4 \\
25.0\end{array}$ & 12 \\
\hline $\begin{array}{l}18-8-5 R 1 \\
18-8-5 R 2\end{array}$ & $\begin{array}{l}19.55 \\
19.55\end{array}$ & $\begin{array}{l}169,200 \\
189,100\end{array}$ & $\begin{array}{l}109,900 \\
101,700\end{array}$ & $\begin{array}{l}258 \\
258\end{array}$ & $\begin{array}{l}20.6 \\
25.6\end{array}$ & 13 \\
\hline $19-7-3-G 2$ & 19.53 & 167,500 & 113,200 & - & 26.4 & 14 \\
\hline $19-8-2-\mathrm{C} 5$ & 19.55 & 178,000 & 106,300 & - & 20.3 & 15 \\
\hline AVERAGE(3) & 19.55 & 175,000 & 107,400 & 263 & 22.8 & -- \\
\hline \multicolumn{7}{|c|}{ (1) Testing speed: 0.015 inches $/$ minute. } \\
\hline \multicolumn{7}{|c|}{ (2) Determined from load-platen displacement curve at point of failure. } \\
\hline \multicolumn{7}{|c|}{$\begin{array}{l}\text { (3) All average values were obtained by first finding the average within each metal group } \\
\text { and then averaging these values for an over all average. This was done because the } \\
\text { material tested in each metal group came from the same casting heat. It was felt that a } \\
\text { more representative and unbiased over all average could be obtained in this way. }\end{array}$} \\
\hline
\end{tabular}




\section{YIELD STRENGTH AND MODULUS OF ELASTICITY IN COMPRESSION ${ }^{(1)}$ AT $30^{\circ} \mathrm{C}$}

\begin{tabular}{|c|c|c|c|c|}
\hline $\begin{array}{l}\text { Specimen } \\
\text { No. }\end{array}$ & $\begin{array}{c}0.01 \% \text { Yield } \\
\text { Strength } \\
\text { (psi) }\end{array}$ & $\begin{array}{c}\text { Modulus of } \\
\text { Elasticity } \\
\left(10^{6} \text { psi) }\right.\end{array}$ & $\begin{array}{l}\text { Density } \\
(\mathrm{g} / \mathrm{cc})\end{array}$ & $\begin{array}{c}\text { Diamond } \\
\text { Pyramid } \\
\text { Hardness } \\
(10 \mathrm{~kg} \text { load } \\
\end{array}$ \\
\hline $18-8-1 C$ & 47,300 & 13.9 & 19.49 & 261 \\
\hline $18-8-1 D$ & 39,600 & 14.5 & 19.55 & $-\infty$ \\
\hline $18-8-40$ & 34,200 & 14.7 & 19.56 & $-\cdots$ \\
\hline $18-8-4 P$ & 32,100 & 14. 2 & 19.56 & 259 \\
\hline $18-8-5 R$ & 37,500 & 14.0 & 19.55 & 258 \\
\hline Average & 38,200 & 14.3 & 19.54 & 259 \\
\hline
\end{tabular}

(1) Testing speed: 0.015 inches $/$ minute; $h / d_{\circ} 5.5$ 
TABLE IX

COMPRESSIVE STRENGTH ${ }^{(1)}$ AND RELATED DATA FOR HIGH DENSITY PLUTONIUM

\begin{tabular}{|c|c|c|c|c|c|c|c|}
\hline $\begin{array}{l}\text { Specimen } \\
\text { Number }\end{array}$ & $\begin{array}{l}\text { Test } \\
\text { Temp. } \\
\text { (C) }\end{array}$ & $\begin{array}{l}\text { Ultimate } \\
\text { Strength } \\
\text { (psi) }\end{array}$ & $\begin{array}{l}\text { Yield } \\
\text { Strength } \\
\quad(p s i)\end{array}$ & $\begin{array}{l}\text { Increase } \\
\text { In Area } \\
\text { PerCent }\end{array}$ & $\begin{array}{l}\text { Plastic } \\
\text { Decrease } \\
\text { In Length (\%) }\end{array}$ & $\begin{array}{l}\text { Density } \\
(\mathrm{g} / \mathrm{cc})\end{array}$ & $\begin{array}{l}\text { Total } \\
\text { Impurity } \\
\text { Content (ppm) }\end{array}$ \\
\hline $\begin{array}{l}19-7-3-\mathrm{E} 4 \\
19-7-3-\mathrm{E} 5\end{array}$ & $\begin{array}{l}-30 \\
-30\end{array}$ & $\begin{array}{l}194,200 \\
190,300\end{array}$ & $\begin{array}{l}161,600 \\
160,600\end{array}$ & - & $\begin{array}{l}4.7(4) \\
4.5(4)\end{array}$ & $\begin{array}{l}19.53 \\
19.53\end{array}$ & $\begin{array}{l}745 \\
745\end{array}$ \\
\hline (3) & 30 & 175,000 & 107,400 & - & $22.7(4)$ & 19.55 & - \\
\hline $\begin{array}{l}19-7-2-\mathrm{D} 5 \\
19-7-3-\mathrm{E} 1\end{array}$ & $\begin{array}{l}73 \\
70\end{array}$ & $118, \overline{400}$ & $\begin{array}{l}74,200 \\
80,200\end{array}$ & - & $\begin{array}{c}26.5(4) \\
-\end{array}$ & $\begin{array}{l}19.54 \\
19.53\end{array}$ & $\begin{array}{l}324 \\
745\end{array}$ \\
\hline $\begin{array}{l}19-7-3-\mathrm{E} 2 \\
19-7-3-\mathrm{E} 3\end{array}$ & $\begin{array}{l}110 \\
110\end{array}$ & $\begin{array}{l}78,300 \\
77,200\end{array}$ & $\begin{array}{l}65,400 \\
64,800\end{array}$ & - & 18. $3(4)$ & $\begin{array}{l}19.53 \\
19.53\end{array}$ & $\begin{array}{l}745 \\
745\end{array}$ \\
\hline $\begin{array}{l}19-5-4-\mathrm{B} 4 \\
19-5-4-\mathrm{A} 3 \\
19-5-4-\mathrm{A} 4 \\
19-6-4-\mathrm{H} 4 \\
19-6-4-\mathrm{G} 1\end{array}$ & $\begin{array}{l}128 \\
130 \\
130 \\
131 \\
130\end{array}$ & $\begin{array}{l}- \\
- \\
- \\
- \\
-\end{array}$ & $\begin{array}{c}- \\
20,900 \\
24,100 \\
24,600 \\
17,700\end{array}$ & $\begin{array}{l}392 \\
409 \\
498 \\
497 \\
436\end{array}$ & $\begin{array}{l}79.8(2) \\
79.9(2) \\
82.2(2) \\
83.3(2) \\
81.6(2)\end{array}$ & $\begin{array}{l}19.59 \\
19.59 \\
19.59 \\
19.56 \\
19.56\end{array}$ & $\begin{array}{l}266 \\
266 \\
266 \\
412 \\
412\end{array}$ \\
\hline $\begin{array}{l}19-5-4-B 3 \\
19-5-4-A 2 \\
19-5-4-C 3\end{array}$ & $\begin{array}{l}149 \\
149 \\
151\end{array}$ & - & $\begin{array}{l}11,650 \\
12,000 \\
11,970\end{array}$ & $\begin{array}{l}557 \\
557 \\
592\end{array}$ & $\begin{array}{l}84.8(2) \\
84.5(2) \\
85.2(2)\end{array}$ & $\begin{array}{l}19.59 \\
19.59 \\
19.59\end{array}$ & $\begin{array}{l}266 \\
266 \\
266\end{array}$ \\
\hline $\begin{array}{l}19-5-4-C 1 \\
19-5-4-C 2\end{array}$ & $\begin{array}{l}176 \\
176\end{array}$ & $=$ & $\begin{array}{l}8,170 \\
8,770\end{array}$ & $\begin{array}{l}625 \\
625\end{array}$ & $\begin{array}{l}86.0(2) \\
85.5(2)\end{array}$ & $\begin{array}{l}19.59 \\
19.59\end{array}$ & $\begin{array}{l}266 \\
266\end{array}$ \\
\hline
\end{tabular}


TABLE IX (Contd.)

\begin{tabular}{|c|c|c|c|c|c|c|c|}
\hline $\begin{array}{l}\text { Specimen } \\
\text { Number }\end{array}$ & $\begin{array}{l}\text { Test } \\
\text { Temp. } \\
\text { (C) }\end{array}$ & $\begin{array}{l}\text { Ultimate } \\
\text { Strength } \\
\text { (psi) }\end{array}$ & $\begin{array}{l}\text { Yield } \\
\text { Strength } \\
\quad(p s i)\end{array}$ & $\begin{array}{l}\text { Increase } \\
\text { In Area } \\
\text { Per Cent }\end{array}$ & $\begin{array}{l}\text { Plastic } \\
\text { Decrease } \\
\text { In Length(\%) }\end{array}$ & $\begin{array}{c}\text { Density } \\
(\mathrm{g} / \mathrm{cc})^{\prime}\end{array}$ & $\begin{array}{l}\text { Total } \\
\text { Impurity } \\
\text { Content(ppm }\end{array}$ \\
\hline $\begin{array}{l}19-5-4-\mathrm{A} 1 \\
19-5-4-\mathrm{D} 4 \\
19-6-4-\mathrm{H} 3\end{array}$ & $\begin{array}{l}189 \\
190 \\
191\end{array}$ & $\begin{array}{l}- \\
- \\
-\end{array}$ & $\begin{array}{l}6,820 \\
7,130 \\
6,910\end{array}$ & $\begin{array}{l}658 \\
658 \\
661\end{array}$ & $\begin{array}{l}86: 6:(2) \\
86.3(2) \\
86.5(2)\end{array}$ & $\begin{array}{l}19.59 \\
19.59 \\
19.56\end{array}$ & $\begin{array}{l}266 \\
266 \\
412\end{array}$ \\
\hline $\begin{array}{l}19-4-3-\mathrm{C} 1 \\
19-4-3-\mathrm{B} 1 \\
19-5-4-\mathrm{B} 5\end{array}$ & $\begin{array}{l}230 \\
231 \\
232\end{array}$ & $\begin{array}{l}- \\
-\end{array}$ & $\begin{array}{l}4,930 \\
5,110 \\
4,530\end{array}$ & $\begin{array}{l}945 \\
841 \\
800\end{array}$ & $\begin{array}{l}89.1(2) \\
87,7(2) \\
88.5(2)\end{array}$ & $\begin{array}{l}19.55 \\
19.55 \\
19.59\end{array}$ & $\begin{array}{l}310 \\
310 \\
266\end{array}$ \\
\hline $\begin{array}{l}19-5-4-\mathrm{B} 2 \\
19-6-4-\mathrm{H} 2\end{array}$ & $\begin{array}{l}266 \\
266\end{array}$ & - & $\begin{array}{l}3,970 \\
4,340\end{array}$ & $\begin{array}{l}957 \\
942\end{array}$ & $\begin{array}{l}90.3(2) \\
90.3(2)\end{array}$ & $\begin{array}{l}19.59 \\
19.56\end{array}$ & $\begin{array}{l}266 \\
412\end{array}$ \\
\hline $\begin{array}{l}19-7-1-A 3 \\
19-5-4 B \\
19-4-3-B 2\end{array}$ & $\begin{array}{l}300 \\
300 \\
300\end{array}$ & $\begin{array}{l}- \\
-\end{array}$ & $\begin{array}{l}3,430 \\
3,380 \\
3,500\end{array}$ & $\begin{array}{l}1145 \\
1353 \\
1196\end{array}$ & $\begin{array}{l}91.4(2) \\
92.6(2) \\
92.2(2)\end{array}$ & $\begin{array}{l}19.56 \\
19.59 \\
19.55\end{array}$ & $\begin{array}{l}343 \\
266 \\
310\end{array}$ \\
\hline $\begin{array}{l}19-4-3 \mathrm{~A} \\
19-7-1-\mathrm{A} 1\end{array}$ & $\begin{array}{l}330 \\
331\end{array}$ & - & $\begin{array}{r}816 \\
1,265\end{array}$ & $\begin{array}{l}1593 \\
1610\end{array}$ & $\begin{array}{l}93.8(2) \\
92.8(2)\end{array}$ & $\begin{array}{l}19.55 \\
19.56\end{array}$ & $\begin{array}{l}310 \\
343\end{array}$ \\
\hline
\end{tabular}

(1) Testing speed: 0.015 inches/minute

(2) After exceeding the yield strength the load was increased at a rapid rate to 100,000 pounds. The increase in area and decrease in length data were taken after unloading and cooling to room temperature.

(3) A total of 15 specimens were tested at this temperature. The average values are reported.

(4) Total plastic decrease in length was determined from load-platen displacement curve at point of failure. 
TABLE X

COMPRESSIVE STRENGTH ${ }^{(1)}$ AND RELATED DATA FOR LOW DENSITY PLUTONIUM

\begin{tabular}{|c|c|c|c|c|c|c|c|}
\hline $\begin{array}{l}\text { Specimen } \\
\text { Number }\end{array}$ & $\begin{array}{l}\text { Test } \\
\text { Temp. } \\
\text { (C) }\end{array}$ & $\begin{array}{l}\text { Ultimate } \\
\text { Strength } \\
\text { (psi) }\end{array}$ & $\begin{array}{l}\text { Yield } \\
\text { Strength } \\
\quad(p s i)\end{array}$ & $\begin{array}{c}\text { Increase } \\
\text { In Area }(2)_{(\%)}\end{array}$ & $\begin{array}{l}\text { Plastic } \\
\text { Decrease } \\
\text { In Length }(\%)\end{array}$ & $\begin{array}{l}\text { Density } \\
(\mathrm{g} / \mathrm{cc})\end{array}$ & $\begin{array}{l}\text { Total } \\
\text { Impurity } \\
\text { Content(ppm) }\end{array}$ \\
\hline (3) & 30 & 168,500 & - & - & - & 19.43 & - \\
\hline $\begin{array}{l}19-2-2-7 \\
19-2-2-10\end{array}$ & $\begin{array}{l}100 \\
100\end{array}$ & $\begin{array}{l}97,500 \\
90,000\end{array}$ & $\begin{array}{l}68,000 \\
67,000\end{array}$ & - & - & $\begin{array}{l}19.41 \\
19.41\end{array}$ & $\begin{array}{l}1467 \\
1467\end{array}$ \\
\hline $\begin{array}{l}19-2-2-3 \\
19-2-2-9 \\
19-2-2-11 \\
19-2-2-12 \\
19-2-2-19\end{array}$ & $\begin{array}{l}150 \\
150 \\
150 \\
150 \\
150\end{array}$ & $\begin{array}{l}- \\
- \\
- \\
-\end{array}$ & $\begin{array}{l}10,880 \\
14,120 \\
12,500 \\
15,300 \\
15,300\end{array}$ & $\begin{array}{c}- \\
- \\
- \\
599 \\
613\end{array}$ & $\begin{array}{l}- \\
- \\
- \\
86.1\end{array}$ & $\begin{array}{l}19.41 \\
19.41 \\
19.41 \\
19.41 \\
19.41\end{array}$ & $\begin{array}{l}1467 \\
1467 \\
1467 \\
1467 \\
1467\end{array}$ \\
\hline $\begin{array}{l}19-2-2-1 \\
19-2-2-4\end{array}$ & $\begin{array}{l}175 \\
175\end{array}$ & - & $\begin{array}{l}8,750 \\
8,160\end{array}$ & $6 \overline{83}$ & 86.8 & $\begin{array}{l}19.41 \\
19.41\end{array}$ & $\begin{array}{l}1467 \\
1467\end{array}$ \\
\hline $\begin{array}{l}19-2-2-2 \\
19-2-2-17\end{array}$ & $\begin{array}{l}190 \\
190\end{array}$ & - & $\begin{array}{l}5,870 \\
5,900\end{array}$ & $7 \overline{25}$ & 87.7 & $\begin{array}{l}19.41 \\
19.41\end{array}$ & $\begin{array}{l}1467 \\
1467\end{array}$ \\
\hline $\begin{array}{l}19-2-2-5 \\
19-2-2-14 \\
19-2-2-16\end{array}$ & $\begin{array}{l}230 \\
230 \\
230\end{array}$ & $\begin{array}{l}- \\
- \\
-\end{array}$ & $\begin{array}{l}6,120 \\
6,830 \\
7,490\end{array}$ & $\begin{array}{l}958 \\
907 \\
853\end{array}$ & $\begin{array}{l}89.3 \\
89.2 \\
89.2\end{array}$ & $\begin{array}{l}19.41 \\
19.41 \\
19.41\end{array}$ & $\begin{array}{l}1467 \\
1467 \\
1467\end{array}$ \\
\hline
\end{tabular}


TABLE X (Contd.)

\begin{tabular}{|c|c|c|c|c|c|c|c|}
\hline $\begin{array}{l}\text { Specimen } \\
\text { Number } \\
\end{array}$ & $\begin{array}{l}\text { Test } \\
\text { Temp. } \\
\text { (C) }\end{array}$ & $\begin{array}{l}\text { Ultimate } \\
\text { Strength } \\
\text { (psi) }\end{array}$ & $\begin{array}{l}\text { Yield } \\
\text { Strength } \\
\text { (psi) }\end{array}$ & $\begin{array}{c}\text { Increase } \\
\text { In Area }(2)(\%) \\
\end{array}$ & $\begin{array}{l}\text { Plastic } \\
\text { Decrease } \\
\text { In Length(\%) }\end{array}$ & $\begin{array}{r}\text { Density } \\
(\mathrm{g} / \mathrm{cc})\end{array}$ & $\begin{array}{l}\text { Total } \\
\text { Impurity } \\
\text { Content(ppm) }\end{array}$ \\
\hline $\begin{array}{l}19-2-2-15 \\
19-2-2-18\end{array}$ & $\begin{array}{l}265 \\
265\end{array}$ & $\overline{-}$ & $\begin{array}{l}5,400 \\
4,700\end{array}$ & $\begin{array}{l}1069 \\
1110\end{array}$ & $\begin{array}{l}91.7 \\
91.7\end{array}$ & $\begin{array}{l}19.41 \\
19.41\end{array}$ & $\begin{array}{l}1467 \\
1467\end{array}$ \\
\hline $\begin{array}{l}19-2-1-4 A \\
19-2-1-3 A\end{array}$ & $\begin{array}{l}300 \\
300\end{array}$ & - & 2,600 & 1072 & 92.7 & $\begin{array}{l}19.45 \\
19.45\end{array}$ & $\begin{array}{l}2300 \\
2300\end{array}$ \\
\hline $\begin{array}{l}19-2-2-25 \\
19-2-1-1 A\end{array}$ & $\begin{array}{l}330 \\
330\end{array}$ & - & $\begin{array}{l}2,350 \\
2,575\end{array}$ & $\begin{array}{c}1473 \\
-\end{array}$ & $\begin{array}{c}94.2 \\
-\end{array}$ & $\begin{array}{l}19.41 \\
19.45\end{array}$ & $\begin{array}{l}1467 \\
2300\end{array}$ \\
\hline
\end{tabular}

(1) Testing speed: 0.015 inches/minute

(2) After exceeding the yield strength the load was increased at a rapid rate to 100,000 pounds. The increase in area and decrease in length data were taken after unloading and cooling to room temperature.

(3) A total of 12 specimens were tested at this temperature. The average values are reported. 


\section{TABLE XI}

EFFECT OF TESTING SPEED IN ALPHA, BETA AND GAMMA PHASES ON COMPRESSIVE STRENGTH

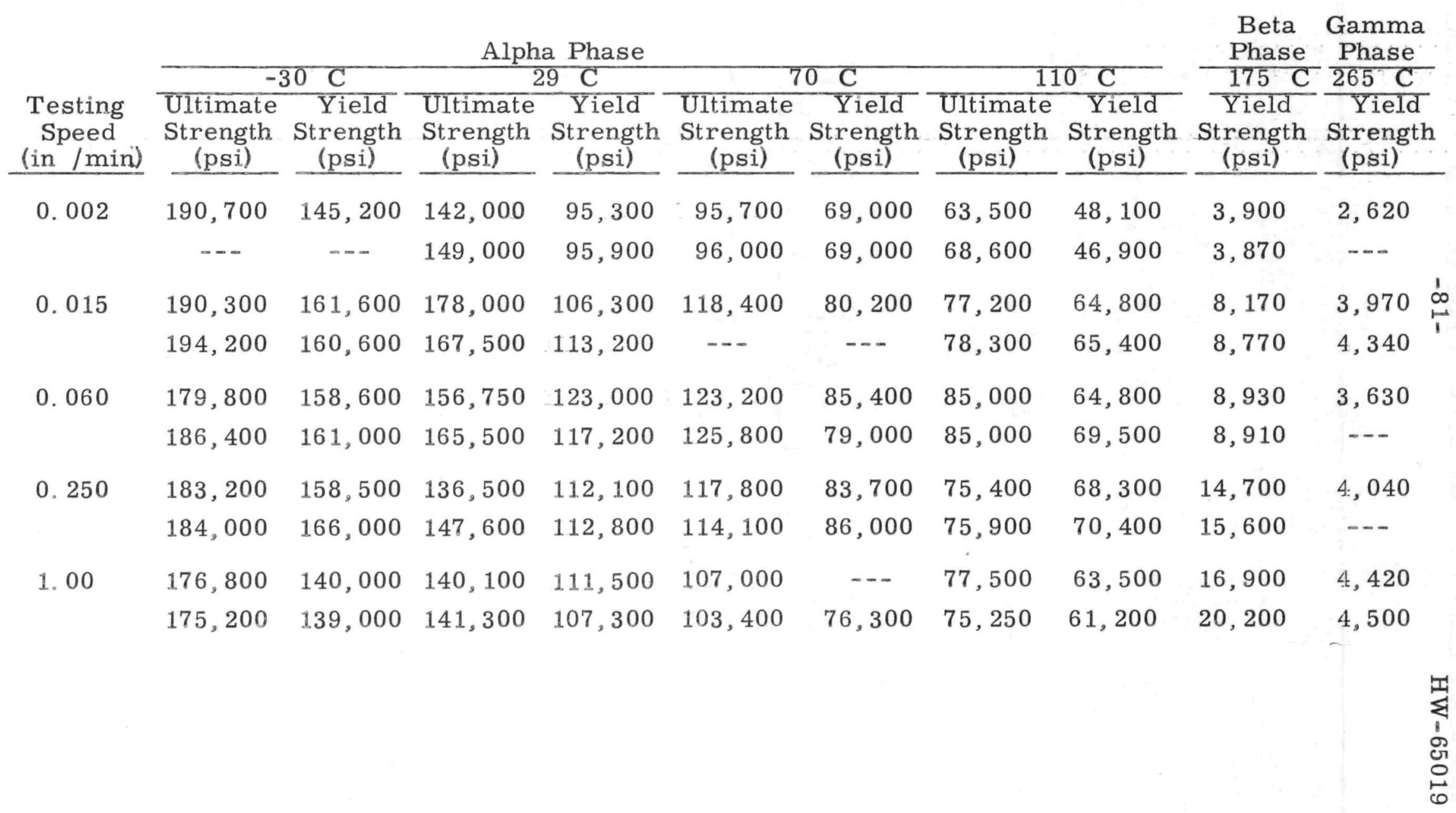




\section{TABLE XII}

\section{EFFECT OF METAL QUALITY ON YIELD STRENGTH OVER A RANGE OF TESTING SPEEDS}

Low Quality Metal

\begin{tabular}{|c|c|c|c|c|}
\hline $\begin{array}{c}\text { Testing } \\
\text { Speed } \\
\text { (inch/minute } \\
\end{array}$ & $\begin{array}{c}\text { Specimen } \\
\text { No. }\end{array}$ & $\begin{array}{l}\text { Yield } \\
\text { Strength } \\
\text { (psi) }\end{array}$ & $\begin{array}{l}\text { Density } \\
(\mathrm{g} / \mathrm{cc})\end{array}$ & $\begin{array}{l}\text { Total } \\
\text { Impurity } \\
\text { Content } \\
\text { (ppm) }\end{array}$ \\
\hline .003 & $19-2-2-22$ & 6650 & 19.41 & 1467 \\
\hline .007 & $19-2-2-24$ & 7650 & 19.41 & 1467 \\
\hline .015 & $19-2-2-4$ & 8700 & 19.41 & 1467 \\
\hline 015 & $19-2-2-1$ & 8960 & 19.41 & 1467 \\
\hline 060 & $19-2-2-20$ & 14,480 & 19.41 & 1467 \\
\hline 125 & $19-2-2-21$ & 17,190 & 19. 41 & 1467 \\
\hline 250 & $19-2-2-23$ & 20,400 & 19.41 & 1467 \\
\hline
\end{tabular}

\section{High Quality Metal}

.002

.002

.015

.015

.060

.060

.250

.250

1. 00

1. 00

$$
\begin{array}{rr}
19-7-1-\mathrm{A}-4 & 3900 \\
19-7-1-\mathrm{A}-5 & 3870 \\
19-5-4-\mathrm{C}-1 & 8170 \\
19-5-4-\mathrm{C}-2 & 8770 \\
19-7-1-\mathrm{A}-6 & 8930 \\
19-7-1-\mathrm{B}-1 & 8910 \\
19-7-1-\mathrm{B}-3 & 15,600 \\
19-7-1-\mathrm{B}-4 & 14,700 \\
19-7-1-\mathrm{B}-5 & 16,900 \\
19-7-1-\mathrm{B}-6 & 20,200
\end{array}
$$

19. 56

19. 56

19. 59

19. 59

19. 56

19. 56

19. 56

19. 56

19. 56

19. 56
343

343

266

266

343

343

343

343

343

343 


\section{TABLE XIII}

TOTAL PLASTIC DEFORMATION IN ALPHA PHASE ${ }^{(1)}$

\begin{tabular}{|c|c|c|c|c|}
\hline $\begin{array}{l}\text { Testing } \\
\text { Speed }\end{array}$ & & astic D & in $\mathrm{Le}$ & $(\%)$ \\
\hline (in $/ \min )$ & $-30: C$ & $30 \mathrm{C}$ & $70^{\circ} \mathrm{C}$ & $110^{\circ} \mathrm{C}$ \\
\hline 0.002 & 7.3 & 27.7 & 23.3 & 15.7 \\
\hline & $\cdots$ & -- & -- & $\cdots$ \\
\hline 0.015 & 4.7 & 26.4 & 26.5 & 18. 3 \\
\hline & 4.3 & 20.3 & -- & -- \\
\hline 0.060 & 2.7 & 15.5 & 28.3 & 20.0 \\
\hline & 2.3 & 18. 8 & --- & 18.3 \\
\hline 0.250 & 3.0 & 21.0 & 24.7 & 12.0 \\
\hline & 2.3 & 17.7 & 26.0 & 18. 3 \\
\hline 1. 00 & 3.0 & 9.0 & 11.0 & 7.7 \\
\hline & 2. 3 & 9.0 & -- & 7.7 \\
\hline
\end{tabular}

(1) Testing speed: 0.015 inches/minute.

(2) Total plastic decrease in length determined from loadplaten displacement curve at point of failure. 


\section{TABLE XIV}

\section{CREEP DATA}

\begin{tabular}{|c|c|c|c|c|c|c|c|}
\hline $\begin{array}{l}\text { Specimen } \\
\text { Number }\end{array}$ & $\begin{array}{l}\text { Test } \\
\text { Temp. } \\
\text { (C) }\end{array}$ & $\begin{array}{l}\text { Applied } \\
\text { Stress } \\
\text { (psi) }\end{array}$ & $\begin{array}{l}\text { Secondary } \\
\text { Creep Rate } \\
\text { (1) }\end{array}$ & $\begin{array}{l}\text { Total } \\
\text { Strain } \\
\left(10^{-4} \text { in /in) }\right.\end{array}$ & $\begin{array}{l}\text { Duration of } \\
\text { Test } \\
\text { (Hours) }\end{array}$ & $\begin{array}{r}\text { Density } \\
(\mathrm{g} / \mathrm{cc})\end{array}$ & $\begin{array}{c}\text { Total } \\
\text { Impurity } \\
\text { Content(ppm) }\end{array}$ \\
\hline $18-10-12 \mathrm{~A}$ & 31.0 & 10,000 & 15.0 & 4.2 & 1370 & 19. 43 & 520 \\
\hline $19-3-2 A$ & 26.0 & 8,000 & 15.2 & 4. 3 & 1850 & 19. 49 & 486 \\
\hline $19-3-2 A$ & 42.3 & 8,000 & $28.2^{(2)}$ & - & 870 & 19. 49 & 486 \\
\hline $18-10-12 B$ & 100.0 & 10,000 & 330.0 & 41.0 & 570 & 19.43 & 425 \\
\hline
\end{tabular}

(1) $10^{-4} \mathrm{in} / \mathrm{in} / 10,000$ hours

(2) Obtained during 870 hour testing period after raising temperature to 42. $3 \mathrm{C}$ from $26.0 \mathrm{C}$ 
TABLE XV

TENSION IMPACT DATA AT $30^{\circ} \mathrm{C}$

$\begin{array}{lc}\begin{array}{c}\text { Specimen } \\ \text { No. }\end{array} & \begin{array}{c}\text { Tension } \\ \text { Impact Value } \\ \text { (ft-1b) }\end{array} \\ \text { 18-9-8C } & 1.4 \\ 18-9-8 \mathrm{D} & 1.6 \\ 18-9-12 \mathrm{E} & 3.5 \\ 18-9-12 \mathrm{~F} & 4.2 \\ 19-2-2 \mathrm{~A} & 2.3 \\ 19-2-2 \mathrm{~B} & 4.8 \\ 19-3-1 \mathrm{~A} & 2.1 \\ 19-3-1 \mathrm{~B} & 1.3 \\ \text { Average } & -2.6\end{array}$

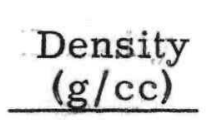

19. 48

19. 48

19. 41

19. 41

19. 51

19. 51

19.53

19. 53

19. 48
Total Impurity Content (ppm)

446

475

1755

1638

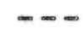

$-\cdots$

773

773

976 
TABLE XVI

DENSITY AND CHEMICAL ANALYSIS ${ }^{(1)}$ DATA FOR EXTRUSION BILLETS

\begin{tabular}{|c|c|c|c|c|c|c|c|c|c|c|c|c|c|c|}
\hline $\begin{array}{l}\text { Billet } \\
\text { Number }\end{array}$ & $\mathrm{Al}$ & $\mathrm{Ca}$ & $\mathrm{Cr}$ & $\mathrm{Cu}$ & $\mathrm{Fe}$ & Mg & Mn & $\mathrm{Ni}$ & $\mathrm{Si}$ & $\mathrm{C}$ & $\begin{array}{l}\text { Total } \\
\text { Impurity }\end{array}$ & $\begin{array}{l}\text { Total } \\
\text { Plutonium } \\
\text { Per Cent }\end{array}$ & $\begin{array}{c}\text { As Cast } \\
\text { Density } \\
(\mathrm{g} / \mathrm{cc})\end{array}$ & $\begin{array}{l}\text { Density } \\
\text { After } \\
\text { Extrusion } \\
(\mathrm{g} / \mathrm{cc})\end{array}$ \\
\hline $18-12-4 A$ & 2 & 2 & 20 & 30 & 500 & 66 & 20 & 66 & 13 & 130 & 853 & - & - & 19.49 \\
\hline $18-12-3 C$ & 4 & 2 & 35 & 8 & 425 & 40 & 8 & 100 & 35 & 478 & 1130 & - & - & 19.55 \\
\hline $19-1-4$ & 5 & 5 & 15 & 10 & 100 & 125 & 75 & 35 & 50 & 135 & 561 & - & - & 19.50 \\
\hline $19-6-3$ & - & - & - & - & - & - & - & - & - & - & 800 & 99.92 & 19.55 & 19.50 \\
\hline $19-6-4$ & - & - & - & - & - & - & - & - & - & - & 1500 & 99.85 & 19.40 & 19. 43 \\
\hline
\end{tabular}

(1) Reported in ppm. 


\section{TABLE XVII}

\section{EXTRUSION DATA}

\begin{tabular}{|c|c|c|c|c|c|c|c|c|c|c|}
\hline $\begin{array}{l}\text { Billet } \\
\text { Number }\end{array}$ & $\begin{array}{l}\text { Billet } \\
\text { Temp. } \\
\text { (C) }\end{array}$ & $\begin{array}{l}\text { Container } \\
\text { Temp. } \\
\text { (C) }\end{array}$ & $\begin{array}{l}\text { Maximum } \\
\text { Extrusion } \\
\text { Pressure } \\
\quad \text { (psi) }\end{array}$ & $\begin{array}{l}\text { Extrusion } \\
\text { Constant } \\
\quad(p s i)\end{array}$ & $\begin{array}{l}\text { Billet } \\
\text { Dia. } \\
\text { (in) }\end{array}$ & $\begin{array}{l}\text { Billet } \\
\text { Length } \\
\text { (in) }\end{array}$ & $\begin{array}{l}\text { Rod } \\
\text { Dia. } \\
\text { Produced } \\
\quad \text { (in) }\end{array}$ & $\begin{array}{l}\text { Rod } \\
\text { Length } \\
\text { Produced } \\
\quad \text { (in) }\end{array}$ & $\begin{array}{l}\text { Type } \\
\text { Extrusion } \\
\text { Die }\end{array}$ & $\begin{array}{l}\text { Extrusior } \\
\text { Die } \\
\text { Throat } \\
\text { ID } \\
\text { (in) }\end{array}$ \\
\hline & & & & Beta & Phase & Extrud & & & & \\
\hline $18-12-4 \mathrm{~A}$ & 168 & 185 & 37,400 & 17,000 & 1.50 & 2.75 & 0.487 & 22.0 & Shear & 0.505 \\
\hline $18-12-3 C$ & 267 & 288 & 24,700 & 11,300 & 1.50 & 2.75 & 0.483 & 21.0 & Shear & 0.505 \\
\hline $19-1-4$ & 283 & 291 & 25,400 & 11,600 & 1.50 & 2.75 & 0.483 & 21.0 & Shear & 0.505 \\
\hline $19-6-4$ & 235 & 300 & 27,200 & 12,000 & 2.39 & 2.25 & 0.749 & 9.5 & Streamline & 0.784 \\
\hline \multicolumn{11}{|c|}{ Delta Phase Extruded } \\
\hline
\end{tabular}


TABLE XVIII

AVERAGE MECHANICAL PROPERTY DATA AT $30 \mathrm{C}^{(1)}$

\begin{tabular}{|c|c|c|c|c|c|c|c|}
\hline $\begin{array}{l}\text { Billet } \\
\text { Number }\end{array}$ & $\begin{array}{c}\text { Phase } \\
\text { Extruded }\end{array}$ & $\begin{array}{l}\text { Ultimate } \\
\text { Tensile } \\
\text { Strength } \\
\text { (psi) }\end{array}$ & $\begin{array}{l}\text { Tensile } \\
0.01 \% \text { Yield } \\
\text { Strength } \\
\text { (psi) }\end{array}$ & $\begin{array}{l}\text { Ultimate } \\
\text { Compres- } \\
\text { sive Strength } \\
\text { (psi) }\end{array}$ & $\begin{array}{c}\text { Total Plastic } \\
\text { Length Decrease } \\
\text { In Compression } \\
\text { Prior to Failure } \\
\text { Per Cent }\end{array}$ & $\begin{array}{l}\text { Modulus of } \\
\text { Elasticity } \\
\text { In Tension } \\
\text { (106 psi) }\end{array}$ & $\begin{array}{r}\text { Diamond } \\
\text { Pyramid } \\
\text { Hardness } \\
(10 \mathrm{~kg} \text { load })\end{array}$ \\
\hline $18-12-4 A$ & Beta & 59,600 & 35,300 & $169,000^{(2)}$ & $27.4^{(2)}$ & 14.9 & 257 \\
\hline $18-12-3 C$ & Gamma & 68,900 & 36,500 & 176,000 & $30.6^{(2)}$ & 14.1 & 267 \\
\hline $19-1-4$ & Gamma & 73,000 & 38,200 & 166,300 & 28.5 & 14.8 & 269 \\
\hline AVERAGE & & 62,800 & 33,000 & 175,000 & 22.8 & 13. 6 & 262 \\
\hline
\end{tabular}

(1) Testing speed: 0.015 inches/minute

(2) Single result 


\section{INTERNAL DISTRIBUTION}

\section{Copy Number}

1

2

3

4

5

6

7

8

9
F. W。Albaugh

L. I. Brecke

W. G. Browne

L。 P。Bupp

S. H. Bush

J. Jo Cadwell

V.R. Cooper

R. E. Falkoski

T. F。 Fisher

M. D。 Freshley

$H$. R。 Gardner

W. S. Hartnett

$\mathrm{H}$ 。 HoHopkins

W. P. Ingalls

Y. B. Katayama

$R$ 。 $R$ 。 King, Jr。

P.S. Kingsley

W. K. MacCready

I. B. Mann

E. D. McClanahan

L. H. McEwen

J. V。 McMaster

L。G。Merker

W. N. Mobley

R. D. Nelson

T. C. Nelson

P. G. Pallmer

$\mathrm{H}$. M. Parker

C. S. Powers

M. N. Raile

J. H. Rector

W. Sale

A. E. Smith

R. E。 Smith

R. W. Stewart

E. O。 Swain

J. M. Taylor

I. D。 Thomas

J. H. Warren

W. B. Weihermiller

O. J. Wick

Record Center

300 File

Extra 
SPECIAL EXTERNAL DISTRIBUTION

Copy Number

64

65

\author{
AEC-HOO, Attn: A. T. Gifford \\ San Francisco Operations Office \\ Attn: R. Wo Hughey
}

\section{EXTERNAL DISTRIBUTION}

No. of Copies

2
1
1
1
1
2
1
1
10
3

Aberdeen Proving Ground

Aerojet-General Corporation

Aerojet-General, San Ramon (IOO-880)

AFPR, Boeing, Seattle

AFPR, Lockheed, Marietta

ANP Project Office, Convair, Fort Worth

Alco Products, Inc.

Allis $\cdots$ Chalmers Manufacturing Company

Argonne National Laboratory

Argonne National Laboratory

Attn: L。 R。 Kelman

R。 M。 Mayfield

L. B. Shuck

Army Ballistic Missile Agency

AEC Scientific Representative, Belgium

AEC Scientific Representative, Japan

Atomic Energy Commission, Washington

Atomics International

Babcock and Wilcox Company (NYOO-1940)

Battelle Memorial. Institute

Bettis Plant

Brookhaven National Laboratory

Brush Beryllium Company

Bureau of Mines, Albany

Bureau of Ships (Code 1500)

Chicago Operations Office

Chicago Patent Group

Combustion Engineering, Inc。

Convair-General Dynamics Corporation, San Diego

Defence Research Member

Denver Research Institute

Department of the Army, G-2

Dow Chemical Company (Rocky Flats)

Dow Chemical Company (Rocky Flats)

Attn: L. A. Matheson for J。G. Epp

Dow Chemical Company (Rocky Flats)

Attn: J. F。Willging

duPont Company, Aiken

duPont Company, Wilmington

Frankford Arsenal

General Atomic Division

General Electric Company (ANPD)

General Electric Company, St. Petersburg 
EXTERNAL DISTRIBUTION (contd.)

No. of Copies

1

1

1

2

2

3

3

6

1

2

1

1

1

1

General Nuclear Engineering Corporation

Goodyear Atomic Corporation

Grand Junction Operations Office

Iowa State University

Jet Propulsion Laboratory

Knolls Atomic Power Laboratory

Los Alamos Scientific Laboratory

Los Alamos Scientific Laboratory

Attn: J. W. Anderson

A. S. Coffinbery

A. E. Gorum

W. J. Maraman

F. W. Shonfeld

R. E. Tate

M \& C Nuclear, Inc.

Mallinckrodt Chemical Works

Maritime Administration

Martin Company

Mound Laboratory

National Aeronautics and Space Administration, Cleveland

National Bureau of Standards

National Bureau of Standards (Library)

National Lead Company of Ohio

Naval Research Laboratory

New Brunswick Area Office

New York Operations Office

Nuclear Development Corporation of America

Nuclear Metals, Inc.

Oak Ridge Institute of Nuclear Studies

Office of Naval Research

Office of Naval Research (Code 422)

Office of Ordnance Research

Olin Mathieson Chemical Corporation

Ordnance Materials Research Office

Ordnance Tank-Automotive Command

Patent Branch, Washington

Phillips Petroleum Company (NRTS)

Picatinny Arsenal

Power Reactor Development Company

Pratt and Whitney Aircraft Division

Rensselaer Polytechnic Institute

Sandia Corporation, Albuquerque

Stevens Institute of Technology (Comstock)

Sylvania Electric Products, Inc.

Technical Research Group

Tennessee Valley Authority

Union Carbide Nuclear Company (ORGDP)

Union Carbide Nuclear Company (ORNL)

Union Carbide Nuclear Company (Paducah Plant) 
EXTERNAL DISTRIBUTION (contd.)

No. of Copies

1

1

1

1

1

1

2

1

2

13

USAF Project RAND

U.S. Geological Survey, Denver

U.S. Geological Survey, Menlo Park

U.S. Geological Survey, Washington

U.S. Naval Postgraduate School

U.S. Patent Office

University of California, Berkeley

University of California, Berkeley

Attn: W. N. Reynolds

University of California, Livermore

University of California, Livermore

Attn: W. Arnold

R。E.Batzel

J. W. Bell

S. C. Godfrey/J。 S. Foster

M. C. Larsen

M. D. Martin

(4) W. J. Ramsey - Information Division

B. Rubin

D. C. Sewell

E. Teller

University of Puerto Rico

Watertown Arsenal

Westinghouse Electric Corporation (Schafer)

Wright Air Development Center

Yankee Atomic Electric Company

Technical Information Service Extension 